\title{
Amino Acid-Protecting Groups
}

Albert Isidro-Llobet, ${ }^{1}$ Mercedes Álvarez, ${ }^{1,2,3^{*}}$ Fernando Albericio ${ }^{1,2,4^{*}}$

${ }^{1}$ Institute for Research in Biomedicine, Barcelona Science Park, Baldiri Reixac 10, 08028Barcelona, Spain.

${ }^{2}$ CIBER-BBN, Networking Centre on Bioengineering, Biomaterials and Nanomedicine, Barcelona Science Park, Baldiri Reixac 10, 08028-Barcelona, Spain.

${ }^{3}$ Laboratory of Organic Chemistry, Faculty of Pharmacy, University of Barcelona, 08028Barcelona, Spain.

${ }^{4}$ Department of Organic Chemistry, University of Barcelona, Martí i Franqués 1, 08028Barcelona, Spain.

E-mail: mercedes.alvarez@irbbarcelona.org; albericio@irbbarcelona.org

\section{RECEIVED DATE}

*Authors to whom correspondence should be addressed. Fax: 349340371 26. E-mail: mercedes.alvarez@irbbarcelona.org; albericio@irbbarcelona.org; 


\section{Contents}

1. Introduction 4

2. $\alpha$-Amino 5

2.1. General 5

2.2 Introduction of the protecting groups 5

2.3 Removal 7

2.3.1. Protecting groups removed by acid 7

2.3.2 Protecting groups removed by base 11

$\begin{array}{ll}\text { 2.3.3 Other protecting groups } & 17\end{array}$

3. Lysine (Lys), Ornithine (Orn), Diaminopropionic acid (Dap) and

Diaminobutyric acid (Dab)

3.1. General 24

3.2 Introduction of the protecting groups 25

$\begin{array}{ll}3.3 \text { Removal } & 25 \\ 3.3 .1 . & 25\end{array}$

3.3.1. Protecting groups removed by acid 25

3.3.2 Protecting groups removed by base 27

$\begin{array}{ll}\text { 3.3.3 Other protecting groups } & 29\end{array}$

4. $\alpha$-Carboxylic acid

4.1. General $\quad 32$

4.2 Introduction of the protecting groups

4.3 Removal 33

4.3.1. Protecting groups removed by acid $\quad 33$

4.3.2 Protecting groups removed by base $\quad 34$

$\begin{array}{ll}\text { 4.3.3 Other protecting groups } & 35\end{array}$

5. Aspartic (Asp) and Glutamic (Glu) acids

5.1. General

5.2 Introduction of the protecting groups 41

5.3 Removal 41

5.3.1. Protecting groups removed by acid 41

5.3.2 Protecting groups removed by base 43

5.3.3 Other protecting groups 43

6. Amide backbone

$\begin{array}{ll}\text { 6.1. General } & 45\end{array}$

6.2 Introduction of the protecting groups 46

6.3 Removal 46

6.3.1. Protecting groups removed by acid 46

6.3.2 Other protecting groups 48

7. Aspargine (Asn) and Glutamine (Gln)
7.1. General

$\begin{array}{ll}7.2 \text { Introduction of the protecting groups } & 51\end{array}$

$\begin{array}{ll}7.3 \text { Removal } & 51\end{array}$

7.3.1. Protecting groups removed by acid 51

8. Arginine (Arg)

$\begin{array}{ll}\text { 8.1. General } & 54\end{array}$

8.2 Introduction of the protecting groups $\quad 55$

8.3 Removal 55

8.3.1. Protecting groups removed by acid $\quad 55$

$\begin{array}{ll}\text { 8.3.2. Protecting groups removed by base } & 58\end{array}$

8.3.3. Other protecting groups $\quad 59$ 
9. Cysteine (Cys)

9.1. General

9.2 Introduction of the protecting groups

9.3 Removal

9.3.1. Protecting groups removed by acid

9.3.2 Protecting groups removed by base

9.3.3 Other protecting groups

10. Methionine (Met)

10.1. General

10.2 Introduction of the protecting groups

10.3 Removal: sulfoxide reduction

11. Histidine (His)

11.1. General

11.2 Introduction of the protecting groups

11.3 Removal

11.3.1. Protecting groups removed by acid 73

11.3.2 Protecting groups removed by base $\quad 75$

11.3.3 Other protecting groups 76

12. Serine (Ser), Threonine (Thr) and Hydroxyproline (Hyp)
12.1. General

12.2 Introduction of the protecting groups

12.3 Removal 78

12.3.1. Protecting groups removed by acid 78

12.3.2 Other protecting groups $\quad 79$

13. Tyrosine (Tyr)

13.1. General 81

13.2 Introduction of the protecting groups 81

13.3 Removal 81

13.3.1. Protecting groups removed by acid 81

13.3.2 Other protecting groups $\quad 84$

14. Tryptophan (Trp)

14.1. General

14.2 Introduction of the protecting groups 86

14.3 Removal 86

14.3.1. Protecting groups removed by acid 86

14.3.2 Protecting groups removed by base $\quad 87$

14.3.3 Other protecting groups $\quad 88$

15. Abbreviations 88

16. References 91 


\section{INTRODUCTION}

Synthetic organic chemistry is based on the concourse of reagents and catalysts to achieve the clean formation of new bonds and appropriate protecting groups are required to prevent the formation of undesired bonds and side-reactions. ${ }^{1,2}$ Thus a promising synthetic strategy can be jeopardized if the corresponding protecting groups are not properly chosen.

Emil Fischer was possibly the first to recognize the need to temporally mask a functional group to allow regioselective bond formation in the synthesis of carbohydrates. ${ }^{3}$ However, the first "modern" protecting group was the benzylozycarbonyl (Z) developed by Bergmann and Zervas. $^{4} \mathrm{Z}$ fits with the main characteristics associated with a protecting group: (i) it is easily introduced into the functional group; (ii) it is stable to a broad range of reaction conditions; and (iii) it is safely removed at the end of the synthetic process or when the functional group requires manipulation. Another cornerstone in this field was when Barany et al. ${ }^{5,6}$ described the concept of orthogonality, in the sense that the two or more protecting groups belong to independent classes and are removed by distinct mechanisms. The groups can be removed therefore in any order and in the presence of the rest. Orthogonal protection schemes are usually milder because selective deprotection is governed by alternative cleavage mechanisms rather than by reaction rates. Since the pioneernig work of Bergmann and Zervas, the development of new protecting groups has been deeply tied to peptide chemistry. Protection is totally mandatory for the construction of these polyfunctional molecules, which contain up to eight distinct functional groups in addition to indole and imidazole rings, which should also be protected. Only the carbonyl function is absent from the natural amino acids, because even phosphate-protecting groups have been developed for the synthesis of phosphopeptides. Thus, the protecting groups first developed for peptide synthesis have been rapidily adapted for the protection of building blocks used for the contruction of non-peptide molecules. ${ }^{1,2}$ Herein, we provide a concise but deep analysis of the protection of amino acids. The review is divided into sections depending on the amino acid funcionalities protected. For each case, methods for the introduction of the protecting groups as well as for their removal are discussed. In each section, protecting groups are classified based on the following criteria: (i) the most used in a Boc/Bn strategy; (ii) the most used in a Fmoc/ ${ }^{t} \mathrm{Bu}$ strategy; (iii) decreased order of lability; and (iv) the most recently described, for which, in most cases, their potential has not yet been explored. In all cases, families of protecting groups are classified together. The compatibility of each protecting group with regard to the others is indicated in the column "Stability to the removal of", which shows which of the following $\alpha$-amino- 
protecting groups (Boc, Fmoc, Z, Trt, Alloc and $p \mathrm{NZ}$ ) can be removed without affecting a particular protector.

Special attention has been given to new protecting groups described in 2000-2008. Those described in the literature earlier and that not have found a broad use have been omitted from this review.

\section{2. $\alpha$-AMINO}

\subsection{General}

Protection of the $\alpha$-amino functionality of amino acids is one of the most important issues in peptide chemistry and is mandatory to prevent polymerization of the amino acid once it is activated.

As most peptide syntheses, both in solution and on solid phase, are carried out in the $C$ to $N$ direction, $\alpha$-amino-protecting groups (temporary protecting groups) are removed several times during the synthesis and therefore removal must be done in mild conditions that do not affect the remaining protecting groups (permanent, usually removed in the last step of the synthetic process, and semi-permanent, usually at the $C$-terminus, removed in the presence of all other protecting groups, when the peptide is to be coupled at its $C$-terminus) or even the peptidic chain.

The $\alpha$-amino-protecting group should confer solubility in the most common solvents and prevent or minimize epimerization during the coupling, and its removal should be fast, efficient, free of side reactions and should render easily eliminated by-products. Other desired characteristics of $\alpha$-amino-protected amino acids are that they are crystalline solids, thereby facilitating manipulation, and stable enough.

The most common $\alpha$-amino-protecting groups for solid-phase peptide synthesis (SPPS) are the 9-fluorenylmethoxycarbonyl (Fmoc) and the tert-butyloxycarbonyl (Boc) groups, used in the Fmoc/tert-butyl $\left({ }^{t} \mathrm{Bu}\right)$ and Boc/benzyl (Bn) strategies respectively.

For solution synthesis, other $\alpha$-amino-protecting groups used are the $Z$, the Nps (2nitrophenylsulfenyl) and the Bpoc [2-(4-biphenyl)isopropoxycarbonyl] in combination with $t$ Bu-type side chain protection; or the Boc group in combination with Bn-type side chain protection.

\subsection{Introduction of the protecting groups}

As there are several types of $\alpha$-amino-protecting groups, there is a wide range of protection methodologies. Most of these are based on the reaction of the free amino acids (side chainprotected if necessary, see $\omega$-amino protection part for selective Lys and Orn side chain 
protection), with an haloformate ${ }^{7}$ or dicarbonate di, $^{8,9}$ of the protecting group under Schotten Baumann conditions (use of biphasic system: organic solvent-aqueous basic conditions) or with the corresponding halide in organic solvents. ${ }^{10}$ Nevertheless, in some cases the presence Comentario [m1]: Refenecia Schotten Baumann of the free $\alpha$-carboxylic acid can interfere in the reaction and lead, for instance, to the formation of dipeptides (Figure 1). ${ }^{11,12,13,14,15,16,17,18}$

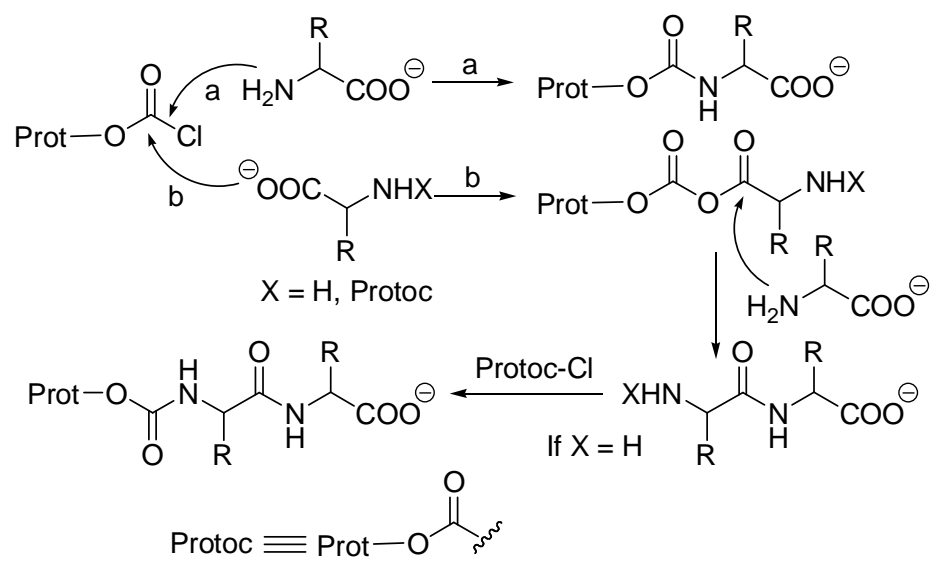

Figure 1. Mechanism for the formation of protected dipeptides during the protection of amino acids with haloformates. Adapted from ${ }^{19}$.

The methodologies used to overcome this problem can be divided into two types: those that involve a carboxylic acid-protecting group which is removed upon amino protection and those that involve less reactive electrophiles on the reagent used to introduce the protecting group. An example of the former is the use of trimethylsilyl esters of amino acids prepared in situ, ${ }^{18,20}$ while an illustration of the latter is the use of $N$-hydroxysuccinimido (HOSu) derivative or the corresponding azide, as in the case of the introduction of Fmoc where Fmoc$\mathrm{OSu}$ or Fmoc- $\mathrm{N}_{3}$ are used instead of Fmoc-Cl. However, the use of Fmoc-OSu can lead to the formation of tiny amounts of Fmoc- $\beta$-Ala-OH or even of Fmoc- $\beta$-Ala-AA-OH (Figure 2 ), which can jeopardize the preparation of Fmoc-amino acids for the production of peptidebased Active Pharmaceutical Ingredients (API). ${ }^{19,21}$ 


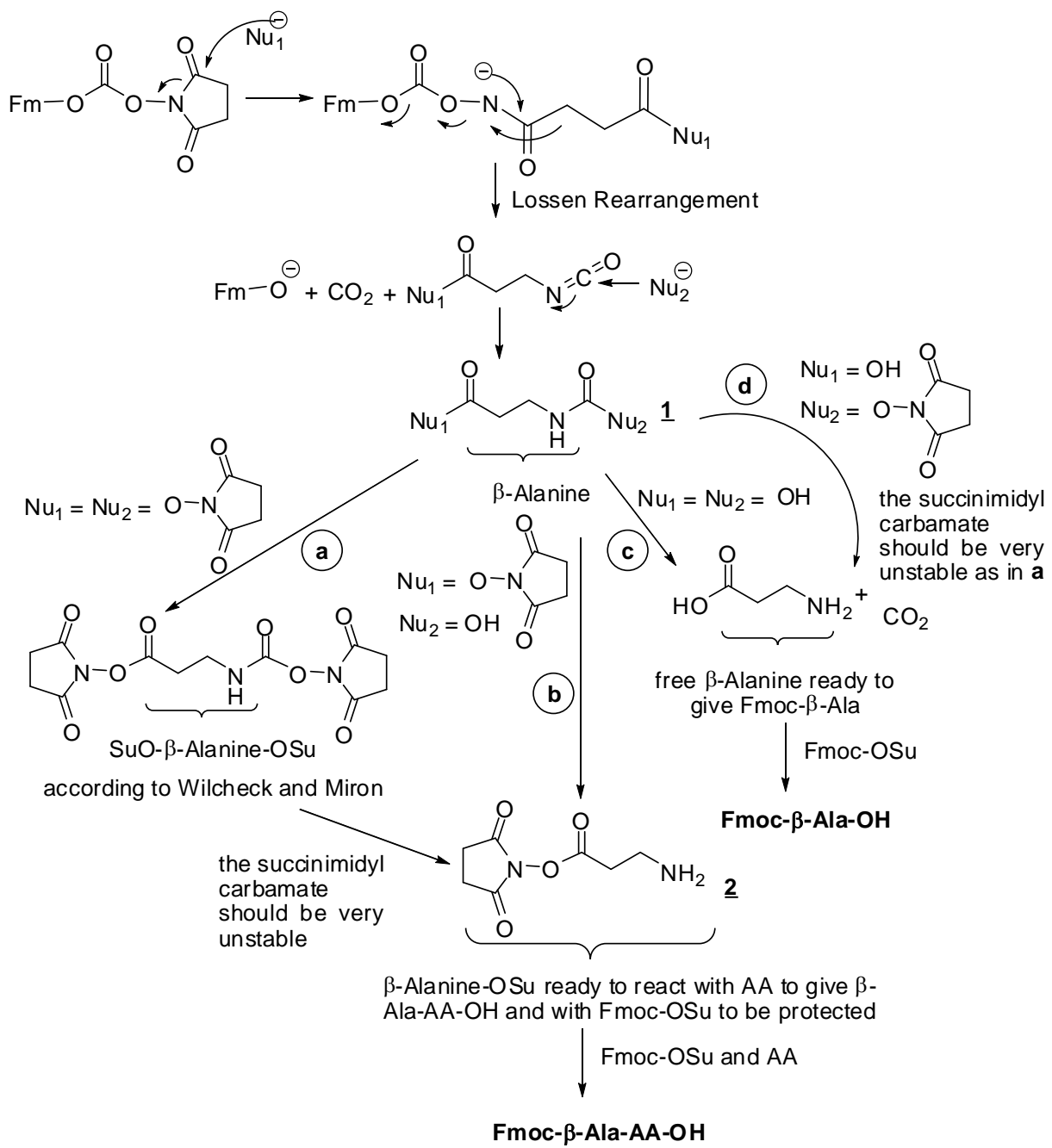

Figure 2. Mechanism for the formation of Fmoc- $\beta$-Ala-OH and Fmoc- $\beta$-Ala-AA-OH during the protection of amino acids. Adapted from 19.

\subsection{Removal}

\subsubsection{Protecting groups removed by acid}

- tert-Butyloxycarbonyl (Boc). ${ }^{22,23}$ Boc-amino acids are generally crystalline solids and their particular suitability for SPPS has been clearly demonstrated. ${ }^{24,25}$ The Boc group has been used for the solid-phase synthesis (SPS) of a number of relevant peptides using the so-called Boc/Bn strategy. The most common removal conditions for Boc are 25-50\% TFA in DCM but other acids, such as $1 \mathrm{M}$ trimethylsilyl chloride (TMS-Cl)-phenol in $\mathrm{DCM},{ }^{26} 4 \mathrm{M} \mathrm{HCl}$ in dioxane and $2 \mathrm{M} \mathrm{MeSO}_{3} \mathrm{H}$ in dioxane, ${ }^{27}$ have been successfully used for solution and solid- 
phase synthetic strategies. The Boc group is stable to bases and nucleophiles as well as to catalytic hydrogenation.

- Trityl (Trt). ${ }^{28,29}$ It is removed with 1\% TFA in DCM or 0.1M HOBt in 2,2,2-trifluoroethanol (TFE) in solution. It can be removed in ever milder conditions such as $0.2 \%$ TFA, $1 \% \mathrm{H}_{2} \mathrm{O}$ in $\mathrm{DCM}^{30}$ or $3 \%$ trichloroacetic acid (TCA) in $\mathrm{DCM},{ }^{31}$ which are compatible with the TFA labile 3-(4-hydroxymethylphenoxy)propionic acid (AB) linker or even with the more acid labile Riniker handle, ${ }^{32}$ as well as with the synthesis of oligonucleotide-peptide conjugates. Coupling yields of Trt-amino acids are lower than those of carbamate-protected amino acids. An important application of the Trt group is for the protection of the second $C$-terminal amino acid in order to prevent diketopiperazines (DKP) formation in a similar way as for the Boc strategy. ${ }^{33,34}$ This procedure involves the coupling of the third amino acid with in situ neutralization after the removal of the Trt group. ${ }^{30}$

Incorporation of Trt-amino acids is more difficult than that of carbamate-protected amino acids, which implies the use of more powerful activating conditions. However, the bulkiness of the Trt group protects the $\alpha$-proton from the base abstraction and therefore makes Trt-AA$\mathrm{OH}$ more difficult to racemize. ${ }^{35}$

- $\alpha, \alpha$-Dimethyl-3,5-dimethoxybenzyloxycarbonyl $(D d z){ }^{36}$ Although Ddz is more acid-stable than the Bpoc and the Trt groups, its removal with 1-5\% TFA in DCM makes it compatible with ${ }^{t} \mathrm{Bu}$-type side chain protection. ${ }^{37}$ It can also be removed by photolysis at wavelengths above $280 \mathrm{~nm},{ }^{36}$ which makes it potentially very useful for SPS library screening procedures. It has been used to prevent DKP formation in the Backbone Amide Linker (BAL) strategy in a similar way as the Trt group. ${ }^{38}$ However, an advantage of Ddz- over Trt-amino acids is that their incorporation is easier, which is a crucial factor when the corresponding amino acids are to be incorporated on hindered amines. ${ }^{38}$

- 2-(4-Biphenyl)isopropoxycarbonyl (Bpoc). ${ }^{39}$ It is a highly acid-sensitive carbamate-type protecting group, which is removed with $0.2-0.5 \%$ of TFA except when used in poly(ethylene glycol)-based resins, in which more TFA is required because some of the acid is used to protonate the oxymethyl moieties. ${ }^{40}$ This is a common characteristic of several acid labileprotecting groups. ${ }^{41}$ Most Bpoc-amino acids are oils and are unstable because the free $\alpha$ carboxylic acid is acidic enough to remove the Bpoc group. Thus, these amino acids are usually stored either as DCHA salts or as pentafluorophenyl esters. ${ }^{42}$ In the early stages of SPPS, before the introduction of Fmoc group, Bpoc-amino acids have been used in combination with ${ }^{t} \mathrm{Bu}$-type side chain protection. ${ }^{40}$ Currently, Bpoc-amino acids are used 
mostly for peptide derivatives containing phosphate groups such as phospopeptides or peptide-oligonucleotide conjugates. ${ }^{43,44}$

- 2-Nitrophenylsulfenyl (Nps). ${ }^{45}$ It is removed most conveniently with diluted solutions of $\mathrm{HCl}$ in $\mathrm{AcOH}^{46}$ It is resistant to bases but can be removed by nucleophiles such as 2mercaptopyridine in combination with $\mathrm{AcOH}$ in $\mathrm{MeOH}, \mathrm{DMF}$ or DCM. ${ }^{47}$ Removal using a Ni Raney column and organic solvents, such as DMF, has also been described. ${ }^{48} \mathrm{Nps}$ has been applied in both solution and SPS. Its high acid lability requires similar precautions to the Bpoc group in the presence of the free $\alpha$-carboxylic acid.

- Benzyloxycarbonyl (Z). See "other protecting groups" 


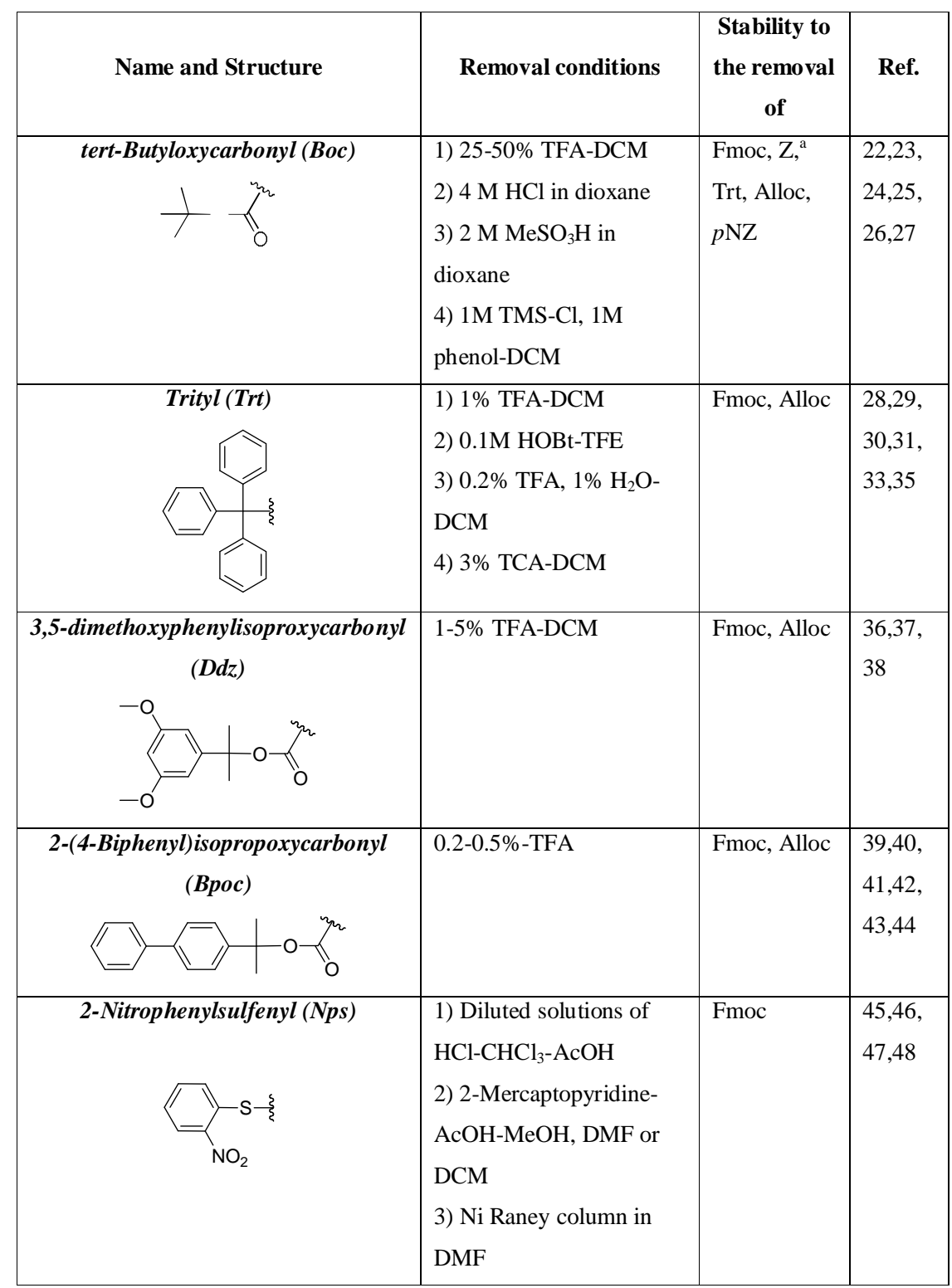

${ }^{a}$ Catalytical hydrogenation removal. 


\subsubsection{Protecting groups removed by base}

- 9-Fluorenylmethoxycarbonyl (Fmoc). ${ }^{49,50}$ It is removed by bases (mainly secondary amines, because they are better at capturing the dibenzofulvene generated during the removal), and is stable to acids. It is not completely stable to the catalytic hydrogenolysis treatment required to remove benzyl esters when $\mathrm{Pd} / \mathrm{C}$ or $\mathrm{PtO}_{2}$ are used as catalysts The most selective catalyst is $\mathrm{Pd} / \mathrm{BaSO}_{4}{ }^{51}$ Solution removal: liquid $\mathrm{NH}_{3}(10$ h) and morpholine or piperidine (within minutes), 10\% diethylamine (DEA), dimethylacetamide (DMA) $(2 \mathrm{~h}),{ }^{52}$ polymeric (silica gel or polystyrene) secondary amines (i.e. piperazine, piperidine) in organic solvents. ${ }^{53,54}$ Applied for the first time for SPPS by two different laboratories independently. ${ }^{55,56}$ Since then, several optimized removal conditions for SPS have been described, the most relevant being: 20\% piperidine in DMF, ${ }^{55}$ which is the most common, $1-5 \%$ DBU in DMF, ${ }^{57,58}$ morpholineDMF $(1: 1)^{59}$ or $2 \% \mathrm{HOBt}, 2 \%$ hexamethyleneimine, $25 \% \mathrm{~N}$-methylpyrrolidine in DMSO-NMP $(1: 1),{ }^{60}$ the latter method leaving thioesters intact. The addition of a relatively small amount of $\mathrm{HOBt}$ to the piperidine solution [0.1 M HOBt in piperidineDMF (2:8)] reduces the formation of aspartimide in the sequences prone to this side reaction. ${ }^{61,62}$

Fmoc $\alpha$-amino protection has been used for the SPS of several relevant peptides using the so-called Fmoc/'Bu strategy, the production in Tm scale of the T20 peptide being one of the most important examples. ${ }^{63}$ Nevertheless, the low solubility of some Fmoc derivatives in the most commonly used solvents for SPPS has stimulated the search for new base-labile protecting groups.

- 2-(4-Nitrophenylsulfonyl)ethoxycarbonyl (Nsc). ${ }^{64}$ It is considered the most promising alternative to the Fmoc group. ${ }^{65,66,67,68}$ Nsc-amino acids are crystalline solids, more soluble in common solvents than Fmoc amino acids, and can be deprotected with 20\% of piperidine or $1 \%$ DBU in DMF or preferably in DMF-dioxane (1:1). ${ }^{64,66}$ Nevertheless, the use of DBU accelerates aspartimide formation and other side reactions. ${ }^{69}$ Nsc is $3-10$ times more base-stable than the Fmoc group, ${ }^{66}$ thereby preventing its undesired removal under slightly basic conditions. This is particularly relevant in the synthesis of polyproline peptides in which the use of the Fmoc group leads to deletions caused by premature Fmoc removal by the secondary amine of Pro whereas no Pro insertions are observed when Nsc is used ${ }^{67}$ Nsc is also important in automated SPS, where amino acid solutions are stored for a long time. Further advantages of the Nsc vs. Fmoc group are that the formation of the olefin-amine adduct 
after removal is irreversible and faster for $\mathrm{Nsc}^{66}$ and Nsc protection reduces racemization compared to Fmoc protection, ${ }^{67}$ which is particularly important in $C$ terminal Ser, Cys and His.

- 1,1-Dioxobenzo[b]thiophene-2-ylmethyloxycarbonyl (Bsmoc). ${ }^{70}$ It is the most important of a series of protecting groups that are removed via a Michael addition. Other protecting groups from the same family are the Bspoc (2-tert-butylsulfonyl-2propenoxycarbonyl $^{71}$ and the Mspoc (2-methylsulfonyl-3-phenyl-1-prop-2enyloxycarbonyl) ${ }^{72}$ and the Mspoc groups. The Michael addition removal mechanism has several advantages over the $\beta$-elimination removal mechanism of Fmoc and Nsc: (i) back alkylation by the $\beta$-elimination by-product is prevented because the deblocking event is also a scavenging event; ${ }^{70}$ (ii) base-catalyzed side reactions, such as aspartimide formation, are minimized as a result of lower concentrations of secondary amines ${ }^{70,73}$ and (iii) the method can be applied to the rapid continuous solution synthesis technique. ${ }^{73,74}$ Bsmoc-amino acids have been used to synthesize several model peptides in which the Bsmoc group was removed with 2-5\% piperidine in $\mathrm{DMF},{ }^{70}$ and have shown better performance than Fmoc amino acids in difficult couplings such as Aib-Aib. ${ }^{41}$ Furthermore, the Bsmoc group can be selectively removed with $2 \%$ of tris(2aminoethyl)amine (TAEA) in DCM in the presence of Fm esters. ${ }^{70}$

- (1,1-Dioxonaphtho[1,2-b]thiophene-2-yl)methyloxycarbonyl $(\alpha-N s m o c) .^{75}$ It is a novel alternative to the Bsmoc group and is removed in the same way but slightly faster. $\alpha$ Nsmoc-amino acids are crystalline solids, thus they are a good alternative to Bsmoc in the cases where Bsmoc-amino acids are oils.

- (1-(4,4-Dimethyl-2,6-dioxocyclohex-1-ylidene)-3-ethyl) (Dde) and 1-(4,4-Dimethyl2,6-dioxocyclohex-1-ylidene)-3-mehtylbutyl (ivDde). Both groups are removed by hydranzinolysis and although can be used for $\alpha$-amino protection, ${ }^{76}$ their principal application is for the protection of Lys and Orn side chains. See Lys and Orn protection. - 2,7-Di-tert-butyl-Fmoc $\left(\right.$ Fmoc $\left.^{*}\right){ }^{77}$ It is removed in the same conditions as the Fmoc group but is up to four times slower. Fmoc*-amino acid derivatives are more soluble than the Fmoc ones. ${ }^{77,78}$ They have been recently used for the synthesis of cyclic modular $\beta$-sheets. ${ }^{79}$

- 2-Fluoro-Fmoc $(F m o c(2 F)) .{ }^{80}$ It is a more base-labile derivative of the Fmoc group and has been used for the SPS of phosphopeptide thioesters. It is removed with a 4-min treatment with $4 \% \mathrm{HOBt}$ in 1-methylpyrrolidine-hexamethylenimine-NMP(1methylpyrrolidin-2-one)-DMSO (25:2:50:50). 
- 2-Monoisooctyl-Fmoc (mio-Fmoc) and 2,7-Diisooctyl-Fmoc (dio-Fmoc). ${ }^{81}$ Both are novel protecting groups reported to show greater solubility than Fmoc* derivatives in DCM-MeOH (100:4). Their removal with 20\% piperidine in DMF is slower than Fmoc removal; 2 times slower in the case of mio-Fmoc and 5 times slower for dio-Fmoc.

- Tetrachlorophthaloyl $(T C P) .{ }^{82}$ It is a relatively new protecting group proposed for SPPS. It is removed with hydrazine in DMF $\left(15 \%\right.$ of hydrazine, at $40{ }^{\circ} \mathrm{C}, 1 \mathrm{~h}$ for repetitive deprotection) but stable to piperidine and to Boc removal conditions. It is also used for side chain amino protection.

- 2-[Phenyl(methyl)sulfonio]ethyloxycarbonyl tetrafluoroborate (Pms). ${ }^{83}$ Pms-amino acids are water-soluble. They have been developed relatively recently and allow SPPS in water. Pms is removed with 5\% aqueous $\mathrm{NaHCO}_{3}, 2 \times 3$ min and $1 \times 30 \mathrm{~min}$ for SPS ${ }^{83,84}$ Nevertheless, since Pms is an onium salt it is rather unstable compared to conventional protecting groups. ${ }^{85}$

- Ethanesulfonylethoxycarbonyl (Esc). ${ }^{85}$ It is another relatively new protecting group for peptide synthesis in water. The deriavatives of Esc are more stable than those of Pms. It is removed either by $0.025 \mathrm{M} \mathrm{NaOH}$ in $\mathrm{H}_{2} \mathrm{O}-\mathrm{EtOH}$ (1:1) or $0.05 \mathrm{M}$ TBAF in DMF.

- 2-(4-Sulfophenylsulfonyl)ethoxycarbonyl (Sps). ${ }^{86}$ Developed parallelly to Esc at almost the same time, it is also a protecting group for SPS in water. It is removed with 5\% aqueous $\mathrm{Na}_{2} \mathrm{CO}_{3}$. Sps-amino acids have a similar stability to Esc ones but with the advantage that they absorb in the UV. 


\begin{tabular}{|c|c|c|c|}
\hline Name and Structure & Removal conditions & $\begin{array}{l}\text { Stability to } \\
\text { the } \\
\text { removal of }\end{array}$ & Ref. \\
\hline 9-Fluorenylmethoxycarbonyl (Fmoc) & $\begin{array}{l}\text { Solid phase: } \\
\text { 1) } 20 \% \text { piperidine-DMF } \\
\text { 2) } 1-5 \% \text { DBU-DMF } \\
\text { 3) morpholine-DMF } \\
\text { (1:1) } \\
\text { 4) } 2 \% \text { HOBt, } 2 \% \\
\text { hexamethyleneimine, } \\
25 \% \text {-methylpyrrolidine } \\
\text { in DMSO-NMP (1:1) } \\
\text { Solution: } \\
\text { 1) NH } \text { (10 h) } \\
\text { 2) morpholine or } \\
\text { piperidine in organic } \\
\text { solvents (within minutes) } \\
\text { 3) } 10 \% \text { DEA,DMA ( } 2 \mathrm{~h} \text { ) } \\
\text { 4) polymeric secondary } \\
\text { amines (i.e. piperidine, } \\
\text { piperazines) in organic } \\
\text { solvents }\end{array}$ & $\begin{array}{l}\text { Boc, } \mathrm{Z}^{\mathrm{a}} \\
\text { Trt, Alloc, } \\
p \mathrm{NZ}^{\mathrm{a}}\end{array}$ & $\begin{array}{l}49,50, \\
51,52, \\
53,54, \\
55,56, \\
57,58, \\
59,60, \\
61,62\end{array}$ \\
\hline $\begin{array}{l}\text { 2-(4-Nitrophenylsulfonyl)ethoxycarbonyl } \\
(\mathrm{Nsc})\end{array}$ & $\begin{array}{l}\text { 1) } 20 \% \text { of piperidine- } \\
\text { DMF or DMF-dioxane } \\
\text { (1:1) } \\
\text { 2) } 1 \% \text { DBU-DMF or } \\
\text { DMF-dioxane }(1: 1)\end{array}$ & $\begin{array}{l}\text { Boc, Trt, } \\
\text { Alloc }\end{array}$ & $\begin{array}{l}64,65 \\
66,67 \\
68,69\end{array}$ \\
\hline $\begin{array}{l}\text { 1,1-Dioxobenzo[b]thiophene-2- } \\
\text { ylmethyloxycarbonyl (Bsmoc) }\end{array}$ & $\begin{array}{l}\text { 1) } 2-5 \% \text { piperidine-DMF } \\
\text { 2) } 2 \% \text { TAEA-DCM }\end{array}$ & $\begin{array}{l}\text { Boc, Trt, } \\
\text { Alloc }\end{array}$ & $\begin{array}{l}70,71 \\
72,73 \\
74\end{array}$ \\
\hline $\begin{array}{c}\text { (1,1-Dioxonaphtho[1,2-b]thiophene-2- } \\
\text { yl)methyloxycarbonyl ( } \alpha \text {-Nsmoc) }\end{array}$ & $\begin{array}{l}\text { 1) } 2-5 \% \text { piperidine-DMF } \\
\text { 2) } 2 \% \text { TAEA-DCM }\end{array}$ & $\begin{array}{l}\text { Boc, Trt, } \\
\text { Alloc }\end{array}$ & 75 \\
\hline
\end{tabular}




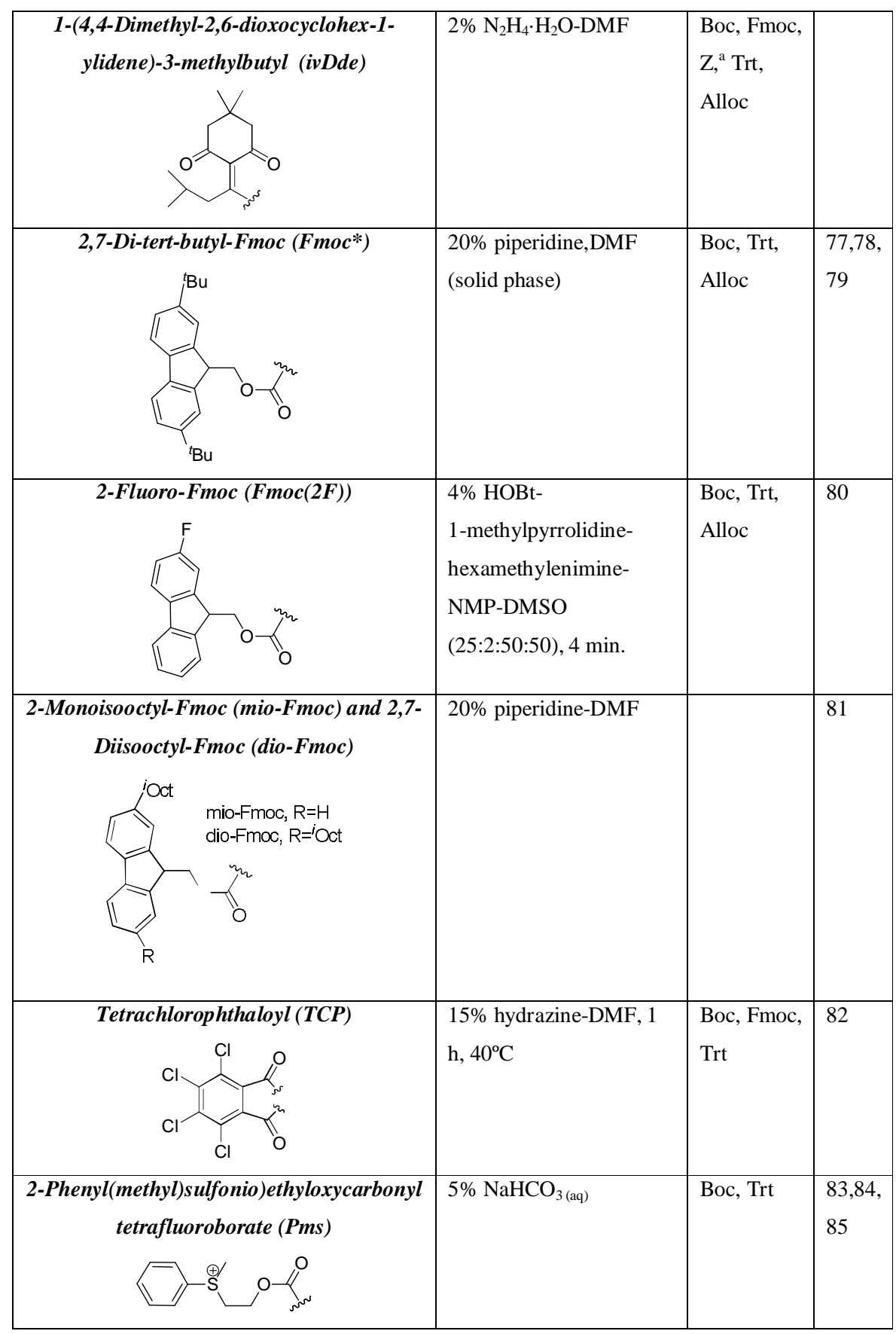




\begin{tabular}{|l|l|l|l|}
\hline Ethanesulfonylethoxycarbonyl (Esc) & $0.025 \mathrm{M} \mathrm{NaOH}-\mathrm{H}_{2} \mathrm{O}-$ & Boc, Trt & 85 \\
\hline 2-(4-sulfophenylsulfonyl)ethoxycarbonyl & $5 \% \mathrm{Na}_{2} \mathrm{CO}_{3(\mathrm{aq})}$ & Boc, Trt & 86 \\
\hline
\end{tabular}

${ }^{a}$ Except catalytical hydrogenation removal. 


\subsubsection{Other protecting groups}

- Benzyloxycarbonyl $(Z){ }^{4}$ It is one of the most widely used $\alpha$-amino-protecting groups for peptide synthesis in solution because of: (i) the easy preparation of Z-protected amino acids; (ii) the high stability of protected amino acids and peptides, which are stable to base and mild acid treatments (stability to Boc removal); (iii) the versatile removal conditions: by catalytical hydrogenolysis during chain elongation or by strong acids ( $\mathrm{HBr}$ in acetic acid, ${ }^{87} \mathrm{TFA}$ at high temperatures, ${ }^{88}$ TFA-thioanisole, ${ }^{89}$ liquid HF, ${ }^{90}$ $\left.\mathrm{BBr}_{3}\right)^{91}$ in the final deprotection of the peptide; and (iv) the supression of racemization during peptide bond formation. ${ }^{92}$

- Allyloxycarbonyl (Alloc)..$^{93,94,95,96,97}$ It is removed by a palladium-catalyzed (usually $\left.\mathrm{Pd}\left(\mathrm{PPh}_{3}\right)_{4}\right)$ transfer of the allyl unit to various nucleophiles/scavengers (preferably: $\mathrm{H}_{3} \mathrm{~N} \cdot \mathrm{BH}_{3}, \mathrm{Me}_{2} \mathrm{NH} \cdot \mathrm{BH}_{3}$ or $\left.\mathrm{PhSiH}_{3}\right)^{98,99}$ in the presence of a proton source. The use of scavengers is mandatory to prevent allylation of the free amine upon Alloc removal. If removed on solid phase, washings with sodium $N, N$-diethyldithiocarbamate $(0.02 \mathrm{M}$ in DMF, $3 \times 15 \mathrm{~min}$ ) are carried out in order to remove Pd. Alloc-amino acids are oils but can be stored as DCHA salts or pentafluorophenyl esters, both of which are crystalline solids. ${ }^{100}$ The use of Alloc group is compatible with the Boc/Bn and Fmoc/t Bu strategies and allows tandem removal-acylation reactions when the palladium-catalyzed amino deblocking is performed in the presence of acylating agents. ${ }^{101}$ This strategy has been used to prevent DKP formation. ${ }^{102}$ Alloc has recently been applied as $\alpha$-aminoprotecting group for a convergent synthesis of the anti-tumoral peptide Kahalalide F. ${ }^{103}$ - o-Nitrobenzenesulfonyl (oNBS) and p-nitrobenzenesulfonyl (pNBS). ${ }^{104}$ The most used is $o$ NBS. It is removed by a nucleophilic aromatic substitution mechanism using $\beta$ mercaptoethanol and DBU when it is protecting $N$-alkyl derivatives but the deblcoking of primary amines fails under these conditions and the cocktail used is $5 \%$ thiophenol in DMF containing 2 eq. of $\mathrm{K}_{2} \mathrm{CO}_{3}$. The main advantage of $o$ NBS- vs Fmoc-amino acids is that the former do not form oxazolones and thus oNBS-amino acyl chlorides can be used in difficult couplings with less risk of racemization. ${ }^{105} o$ NBS $\alpha$-amino-protection is also used for site-specific alkylation of amino acids on solid phase, ${ }^{106,107}$ making these groups unique for the preparation of $N$-Me peptides (Figure 3). 


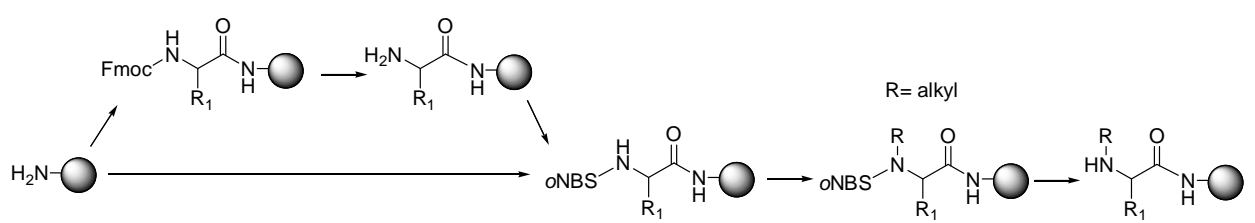

Figure 3. $o$ NBS protection for the synthesis of $N$-alkyl peptides. Reprinted with permission from ref. 106 and 107. Copyright 1997, 2005, American Chemical Society.

- 2,4-Dinitrobenzenesulfonyl (dNBS). ${ }^{108}$ It is removed by treatment with $\mathrm{HSCH}_{2} \mathrm{CO}_{2} \mathrm{H}$ (1.2 eq.) and TEA (3 eq.) in DCM for $30 \mathrm{~min}$, leaving oNBS unaltered.

- Benzothiazole-2-sulfonyl (Bts). ${ }^{105,109}$ Used in solution in a similar way to NBS groups. It is removed using thiophenol and base $\left(\mathrm{K}_{2} \mathrm{CO}_{3}\right.$, DIPEA or $\left.{ }^{t} \mathrm{BuOK}\right)$ in both primary and secondary amines, $\mathrm{NaBH}_{4}$ in $\mathrm{EtOH}^{41}$ or $\mathrm{HS}\left(\mathrm{CH}_{2}\right)_{2} \mathrm{CO}_{2} \mathrm{H}, \mathrm{Na}_{2} \mathrm{CO}_{3}$ in $\mathrm{DMF}^{110}$ for secondary amines, and other reducing agents, such as $\mathrm{Zn}, \mathrm{H}_{3} \mathrm{PO}_{2}, \mathrm{Al} / \mathrm{Hg},{ }^{105}$ which can be used for primary and secondary amines. However, in the latter case the reaction is slower and highly concentration-dependent. Bts has been used for the synthesis of the cyclosporin 8-11 tetrapeptide subunit, which contains three $\mathrm{N}$ methylamino acids, ${ }^{109}$ and more recently for the synthesis of macrocyclic antagonists of the Human Motilin Receptor. ${ }^{111}$

- 2-Nitrophenylsulfanyl (Nps): See protecting groups removed by acid.

- 2,2,2-Trichloroethyloxycarbonyl (Troc). ${ }^{112}$ It is a classical protecting group that can be removed selectively in the presence of Z, Boc, Fmoc and Alloc groups via a Grob fragmentation using $\mathrm{Zn}$ dust in $90 \%$ aqueous $\mathrm{AcOH}$ or other reducing agents. ${ }^{112,113}$ It is not stable to catalytic hydrogenolysis.

- Dithiasuccinoyl (Dts). ${ }^{114}$ It is removed with mild thiolysis using $0.5 \mathrm{M} \beta$ mercaptoethanol and 0.5 M DIPEA in DCM or $0.5 \mathrm{M} \mathrm{N}$-methyl mercaptoacetamide (NMM) in DCM. ${ }^{115}$ It was used for $\alpha$-amino protection in the first three-dimensional orthogonal protection scheme suitable for the preparation of fully and partially protected peptides, which also involved tert-butyl type groups for side chain protection and an $o$ nitrobenzyl ester linkage. ${ }^{6}$ Although Dts is not commonly used for the synthesis of peptides, it has proved useful for the synthesis of peptide nucleic acids (PNA) ${ }^{116}$ and $O$ glycopeptides by protecting the 2-amino substituent in the corresponding glycosyl donors. $^{117}$

- $p$-Nitrobenzyloxycarbonyl $(p N Z){ }^{118}$ It is a classical protecting group which has recently found further applicability for the synthesis of complex peptides as well as for 
minimizing side-reactions. ${ }^{119}$ It is much more stable to strong acids than the $\mathrm{Z}$ group and is removed by reduction with tin(II) chloride in nearly neutral conditions (1.6 mM $\left.\mathrm{HCl}_{(\text {dioxane) }}\right)$ in solid-phase and in solution synthesis, ${ }^{119,103}$ as well as by catalytic hydrogenolysis or $\mathrm{Na}_{2} \mathrm{~S}_{2} \mathrm{O}_{4}{ }^{120}$ for solution synthesis. $p \mathrm{NZ}$ is orthogonal to the three most important amino-protecting groups, Boc, Fmoc, and Alloc, thereby making it highly suitable for the synthesis of cyclic complex peptides such as oxathiocoraline. ${ }^{121}$ If the second $C$-terminal amino acid in SPPS is introduced as $p \mathrm{NZ}$ derivative and the $p \mathrm{NZ}$ group is removed using $\mathrm{SnCl}_{2}$ and catalytic ammounts of $\mathrm{HCl}$, the formation of DKP is prevented. The formation of aspartimides is also prevented using $p$ NZ-amino acids from the Asp residue to the $N$-terminus. ${ }^{119}$

- $\alpha$-Azido carboxylic acids. ${ }^{122,123}$ Although not widely used because of the instability of azides, there are examples of their successful application in SPPS. ${ }^{124,125}$ The azide is reduced to amine using trimethylphospine in dioxane. $\alpha$-Azido carboxylic acids can be coupled as acyl chlorides without oxazolone formation.

- Propargyloxycarbonyl (Poc). ${ }^{126,127}$ It is removed by ultrasonic irradiation in the presence of tetrathiomolybdate complexes such as $\left[\left(\mathrm{PhCH}_{2} \mathrm{NEt}_{3}\right)_{2} \mathrm{MoS}_{4}\right]$ in AcCN. It is a relatively new and still not widely used protecting group for solution-phase peptide synthesis. It is stable to Boc removal conditions and has been used to protect amino acid chlorides to be used in couplings on hindered amines without racemization.

- o-Nitrobenzyloxycarbonyl (oNZ) and 6-Nitroveratryloxycarbonyl (NVOC). ${ }^{128}$ They are removed by photolysis at wavelengths greater than $320 \mathrm{~nm}$ in the presence of additives such as $\mathrm{N}_{2} \mathrm{H}_{4}, \mathrm{NH}_{2} \mathrm{OH} \cdot \mathrm{HCl}$, or semicarbazide hydrochloride for several hours, $o \mathrm{NZ}$ being the most easily removed. NVOC has been used for combinatorial library production using the Affymax methodology. ${ }^{129}$ Research effort is being made to develop more easily removable photolabile protecting groups.

- 2-(2-Nitrophenyl)propyloxycarbonyl (NPPOC). ${ }^{130}$ It is a photolabile amino-protecting group that is removed by UV light $(\lambda=365 \mathrm{~nm})$ about twice as fast as the classical NVOC group.

- 2-(3,4-Methylenedioxy-6-nitrophenyl)propyloxycarbonyl (MNPPOC). ${ }^{131}$ It is removed faster than the NPPOC and has been developed recently by the same research group.

- Ninhydrin (Nin). See Cys protection.

- 9-(4-Bromophenyl)-9-fluorenyl $(B r P h F) .{ }^{132}$ It is a recently proposed safety-catch amino-protecting group and has been tested only for solution synthesis. It prevents epimerization and is more acid stable than the Trt group due to the the anti-aromatic 
nature of the fluorenyl group. ${ }^{t} \mathrm{Bu}$ esters can be selectively cleaved in its presence by using $\mathrm{ZnBr}_{2}$ in DCM or trichloroacetic acid. ${ }^{133,132} \mathrm{BrPhF}$ is removed by Pd-catalyzed aminolysis with morpholine, followed by treatment of the resulting acid-labile morpholine adduct with DCA and triethylsilane (TES) in DCM.

- Azidomethyloxycarbonyl (Azoc). ${ }^{134}$ It is a novel protecting group proposed for solution- and solid-phase synthesis. It is removed by reduction of the azide with phosphines. The removal is rapid when $\mathrm{PMe}_{3}$ or $\mathrm{PBu}_{3}$ (5 min on solid phase) are used, and slower with polymer-bound $\mathrm{PPh}_{3}$ (30 min). Azoc is orthogonal to Fmoc and Mtt.

- Bidentate protecting groups. ${ }^{135}$ Another possibility is the use of bidentate reagents such as $N$-carboxy anhydrides (NCA) and the oxazolidinones derived from hexafluoroacetone (HFA) or formaldehyde, which undergo heterocyclization with the amino and the $\alpha$-carboxylic group. In the heterocycle, the carboxylic group is electrophilic, and a carboxy-derivatization is accompanied by $N$-deprotection (Figure 4).

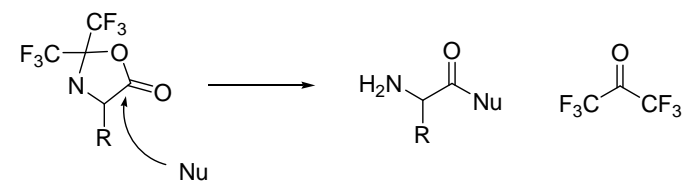

Figure 4. Deprotection of a HFA-protected amino acid via nucleophilic attack 


\begin{tabular}{|c|c|c|c|}
\hline Name and Structure & Removal conditions & $\begin{array}{c}\text { Stability to } \\
\text { the removal } \\
\text { of }\end{array}$ & Ref. \\
\hline $\begin{array}{c}\text { Benzyloxycarbonyl }(Z) \\
\circ\end{array}$ & $\begin{array}{l}\text { 1) } \mathrm{H}_{2} \text { cat } \\
\text { 2) Strong acids such as: } \\
\mathrm{HBr} \text { in } \mathrm{AcOH}, \mathrm{TFA} \text { at } \\
\text { high temperatures, TFA- } \\
\text { thioanisole or liquid HF } \\
\text { 3) } \mathrm{BBr}_{3}\end{array}$ & $\begin{array}{l}\text { Boc, Fmoc, } \\
\text { Trt, Alloc, } \\
p_{\mathrm{NZ}}{ }^{\mathrm{a}}\end{array}$ & $\begin{array}{l}4,87,88,89 \\
90,91,92\end{array}$ \\
\hline Allyloxycarbonyl (Alloc) & $\begin{array}{l}\mathrm{Pd}(\mathrm{PPh})_{3} \text { cat., scavengers: } \\
\mathrm{H}_{3} \mathrm{~N} \cdot \mathrm{BH}_{3}, \mathrm{Me}_{2} \mathrm{NH} \cdot \mathrm{BH}_{3} \text { or } \\
\mathrm{PhSiH}_{3} \text { in organic solvents }\end{array}$ & $\begin{array}{l}\text { Boc, Fmoc, } \\
\text { Trt, } p \mathrm{NZ}^{\mathrm{a}}\end{array}$ & $\begin{array}{l}93,94,95, \\
96,97,98, \\
99,100,101, \\
102,103\end{array}$ \\
\hline $\begin{array}{l}\text { o-Nitrobenzenesulfonyl } \\
\text { (oNBS) }\end{array}$ & $\begin{array}{l}\text { 1) } 5 \% \text { thiophenol-DMF, } 2 \\
\text { eq. of } \mathrm{K}_{2} \mathrm{CO}_{3} \text { (primary } \\
\text { amines) } \\
\text { 2) } \beta \text {-mercaptoethanol and } \\
\text { DBU (secondary amines) }\end{array}$ & $\begin{array}{l}\text { Boc, Fmoc, } \\
\text { Trt }\end{array}$ & $\begin{array}{l}104,105, \\
106,107\end{array}$ \\
\hline $\begin{array}{c}\text { 2,4-Dinitrobenzenesulfonyl } \\
(d N B S)\end{array}$ & $\begin{array}{l}\mathrm{HSCH}_{2} \mathrm{CO}_{2} \mathrm{H} \text { (1.2 eq.), } \\
\text { TEA ( } 3 \text { eq.) in DCM }\end{array}$ & Boc, Trt & 108 \\
\hline Benzothiazole-2-sulfonyl (Bts) & $\begin{array}{l}\text { 1) } \mathrm{Al} / \mathrm{Hg} \\
\text { 2) } \mathrm{Zn} \\
\text { 3) } \mathrm{H}_{3} \mathrm{PO}_{2} \\
\text { 4) } \mathrm{PhSH}_{\text {and base }\left(\mathrm{K}_{2} \mathrm{CO}_{3} \text {, }\right.} \\
\text { DIPEA, potassium tert- } \\
\text { butoxyde) } \\
\text { 5) } \mathrm{NaBH}_{4} \text { in } \mathrm{EtOH}\end{array}$ & - & $\begin{array}{l}41,105,109, \\
110,111\end{array}$ \\
\hline $\begin{array}{c}\text { 2,2,2- } \\
\text { Trichloroethyloxycarbonyl } \\
(\text { Troc) }\end{array}$ & $\mathrm{Zn}$ in $90 \% \mathrm{AcOH}_{(\mathrm{aq})}$ & $\begin{array}{l}\text { Boc, Fmoc, } \\
\text { Trt }\end{array}$ & 112,113 \\
\hline
\end{tabular}




\begin{tabular}{|c|c|c|c|}
\hline Dithiasuccinoyl (Dts) & $\begin{array}{l}\text { 1) } 0.5 \mathrm{M} \beta \text { - } \\
\text { mercaptoethanol and } 0.5 \\
\text { M DIPEA-DCM } \\
\text { 2) } 0.5 \mathrm{M} \mathrm{N} \text { - } \\
\text { methylmercaptoacetamide- } \\
\text { NMM-DCM }\end{array}$ & Boc, Trt & $\begin{array}{l}6,114,115, \\
116,117\end{array}$ \\
\hline $\begin{array}{c}\text { p-Nitrobenzyloxycarbonyl } \\
(p N Z) \\
\end{array}$ & $\begin{array}{l}\text { 1) } 1-6 \mathrm{M} \mathrm{SnCl}_{2}, 1.6 \mathrm{mM} \\
\mathrm{HCl}_{\text {(dioxane) }} \text { in } \mathrm{DMF} \\
\text { 2) } \mathrm{H}_{2} \text { cat }\end{array}$ & $\begin{array}{l}\text { Boc, Fmoc, } \\
\text { Trt, Alloc }\end{array}$ & $\begin{array}{l}103,118,119, \\
120,121\end{array}$ \\
\hline $\begin{array}{l}\boldsymbol{\alpha} \text {-Azidoacids } \\
\mathbf{N}_{\mathbf{3}} \smile \mathrm{COOH}\end{array}$ & $\mathrm{PMe}_{3}$ in dioxane & - & $\begin{array}{l}122,123,124, \\
125\end{array}$ \\
\hline Propargyloxycarbonyl (Poc) & $\begin{array}{l}{\left[\left(\mathrm{PhCH}_{2} \mathrm{NEt}_{3}\right)_{2} \mathrm{MoS}_{4}\right] \text { in }} \\
\text { AcCN (ultrasonic } \\
\text { irradiation) }\end{array}$ & Boc & 126,127 \\
\hline $\begin{array}{c}\text { o-Nitrobenzyloxycarbonyl } \\
\text { (oNZ) } \\
\mathrm{NO}_{2}\end{array}$ & $\begin{array}{l}\text { photolysis }(\lambda>320 \mathrm{~nm}) \text {, } \\
\text { additives: } \mathrm{N}_{2} \mathrm{H}_{4} \text {, } \\
\mathrm{NH}_{2} \mathrm{OH} \cdot \mathrm{HCl} \text {, or } \\
\text { semicarbazide } \cdot \mathrm{HCl} \\
\text { (several hours) }\end{array}$ & $\begin{array}{l}\text { Boc, Fmoc, } \\
\text { Trt, Alloc }\end{array}$ & 128 \\
\hline $\begin{array}{l}\text { 4-Nitroveratryloxycarbonyl } \\
\text { (NVOC) }\end{array}$ & $\begin{array}{l}\text { photolysis }(\lambda>320 \mathrm{~nm}), \\
\text { additives: } \mathrm{N}_{2} \mathrm{H}_{4}, \\
\mathrm{NH}_{2} \mathrm{OH} \cdot \mathrm{HCl} \text {, or } \\
\text { semicarbazide } \cdot \mathrm{HCl} \\
\text { (several hours) }\end{array}$ & $\begin{array}{l}\text { Boc, Fmoc, } \\
\text { Trt, Alloc }\end{array}$ & 128,129 \\
\hline $\begin{array}{c}2-(2- \\
\text { Nitrophenyl)propyloxycarbonyl } \\
(\text { NPPOC }) \\
\mathrm{NO}_{2}\end{array}$ & $\begin{array}{l}\text { photolysis }(\lambda=365 \mathrm{~nm}) \text {, } \\
\text { additives: } 2.5 \mathrm{mM} \\
\text { semicarbazide } \cdot \mathrm{HCl} \text { in } \\
\mathrm{MeOH}\end{array}$ & $\begin{array}{l}\text { Boc, Fmoc, } \\
\text { Trt, Alloc }\end{array}$ & 130 \\
\hline $\begin{array}{c}\text { 2-(3, 4-Methylenedioxy-6- } \\
\text { nitrophenyl) } \\
\text { propyloxycarbonyl (MNPPOC) }\end{array}$ & photolysis $((\lambda>350 \mathrm{~nm}))$ & $\begin{array}{l}\text { Boc, Fmoc, } \\
\text { Trt, Alloc }\end{array}$ & 131 \\
\hline
\end{tabular}




\begin{tabular}{|c|c|c|c|}
\hline $\begin{array}{c}\text { 9-(4-Bromophenyl)-9- } \\
\text { fluorenyl (BrPhF) } \\
\mathrm{Br}\end{array}$ & $\begin{array}{l}\text { i) } 2.5 \text { mmol } \mathrm{Pd}(\mathrm{OAc})_{2}(0.05 \\
\text { eq.), BINAP }(0.05 \text { eq. }) \text {, dry } \\
\mathrm{Cs}_{2} \mathrm{CO}_{3}(5 \text { eq. }) \text {, } \\
\text { morpholine ( } 1.2 \text { eq.) in } \\
\text { toluene at reflux, } 24 \mathrm{~h} \text {. } \\
\text { (ii) DCA-TES-DCM } \\
\text { (14:3:83), } 30 \text { min. }\end{array}$ & - & 132,133 \\
\hline $\begin{array}{c}\text { Azidomethyloxycarbonyl } \\
\text { (Azoc) } \\
\circ\end{array}$ & 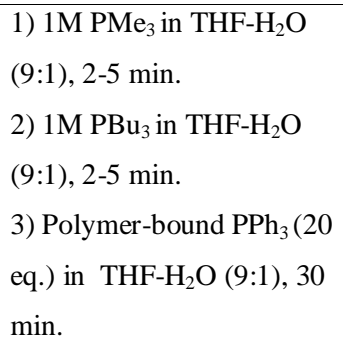 & Fmoc & 134 \\
\hline $\begin{array}{c}\text { Hexafluoroacetone (HFA) } \\
\mathrm{CF}_{3}\end{array}$ & $\begin{array}{l}\text { Nucleophiles (i.e. alcohols, } \\
\text { amines, } \mathrm{H}_{2} \mathrm{O} \text { ) }\end{array}$ & $\begin{array}{l}\text { Boc, Trt, } \\
\text { Alloc }^{\text {b }}\end{array}$ & 135 \\
\hline
\end{tabular}

${ }^{\mathrm{a}}$ Except catalytical hydrogenation removal.

${ }^{\mathrm{b}} \mathrm{Using} \mathrm{PhSiH}_{3}$ as scavenger. 


\section{LYSINE (Lys), ORNITHINE (Orn), DIAMINOPROPIONIC ACID (Dap) AND DIAMINOBUTYRIC ACID (Dab)}

\subsection{General}

The protection of the side chains of lysine (Lys) and ornithine (Orn) as well as diaminopropionc acid (Dap) and diaminobutyric acid (Dab) (Figure 5) is essential in peptide synthesis to prevent their acylation, which would lead to the formation of undesired branched peptides.

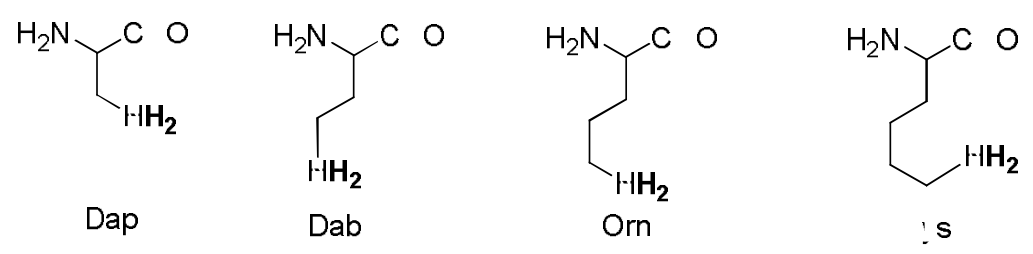

Figure 5. Diaminopropionic acid (Dap), Diaminobutyric acid (Dab), Ornithine (Orn), and Lysine (Lys)

Several groups used for the $\alpha$-amino funcionality have found application for amino side chain protection. It is worth commenting that $\omega$-amino protection is more difficult to remove than $\alpha$-amino protection because of the higher basicity of the former. Thus, for instance, in the case of trityl-type protection of the $\alpha$-amino, the Trt group is used, whereas for the $\omega$-amino the more electron-rich 4-methyltrityl (Mtt) is preferred.

The most used permanent protecting groups for Orn and Lys side chains are the 2chlorobenzyloxycarbonyl (Cl-Z) and $\mathrm{Z}$ groups in the Boc/Bn strategy, and the Boc group in the Fmoc/ $/ \mathrm{Bu}$ strategy. In the synthesis of branched or cyclic peptides there are several protecting groups orthogonal to Boc and Fmoc, Alloc being among the most popular.

The $N^{\alpha}$-Fmoc protecting group can be prematurely removed by a primary amine of sufficient basicity, such as the $\varepsilon$-amino group of Lys and to a lesser extent the $\delta$-amino of Orn and the $\gamma$-amino of Dab, present in the peptide. ${ }^{136,137}$ This side-reaction is not promoted by either the $\beta$-amino side chain of the Dap residue or the $\alpha$-amino group. These results are consistent with the $p$ Ka values of these amino functions in the model compounds shown in Table 1. Thus, while the $p$ Ka values of the side amino functions of Lys, Orn, and Dab are very close, the $p$ Ka of Dap is lower by one unit, making this 
amino function less basic than the other derivatives. The same explanation applies for the $\alpha$-amino function.

Table 1. $p$ Ka of amino function according to the pKalc module (PALLAS version 2.0, CompuDrug).

\begin{tabular}{|c|c|c|c|c|}
\hline & & & & \\
\hline $\mathrm{H}_{2} \mathrm{~N} \underset{\mathrm{NH}_{2}}{\stackrel{\mathrm{O}}{\Perp}}$ & $\mathrm{H}_{\mathrm{H}_{2} \mathrm{~N}^{\prime}}$ & ${ }^{\mathrm{O}} \pi^{\mathrm{N}} \prod_{\mathrm{NH}_{2}}^{\mathrm{N}}$ & $\mathrm{H}_{2} \mathrm{~N}^{\prime}$ & $\pi^{\mathrm{H}} \quad \mathrm{O}$ \\
\hline$p$ Ka: 8.04 & $p$ Ka: 8.49 & $p$ Ka: 9.45 & $p$ Ka: 10.00 & $p$ Ka: 10.09 \\
\hline
\end{tabular}

These $p \mathrm{Ka}$ values must be taken into consideration when the $\omega$-amino-protecting group of Lys, Orn, or Dab is removed in the presence of an $\alpha$-amino protected by the Fmoc group. An alternative is a change of strategy, e.g. use of Alloc or Mtt for $\alpha$-amino and Fmoc for $\omega$-amino protection, use of Mtt for $\omega$-amino protection and a coupling/neutralization protocol similar to that used to prevent DKP formation after Mtt removal, or use of Alloc and a tandem deprotection-coupling reaction. ${ }^{136}$

\subsection{Introduction of the protecting groups}

For blocking the $\alpha$-amino function, a safe method is copper (II) complexation where $\mathrm{CuSO}_{4} \cdot 5 \mathrm{H}_{2} \mathrm{O}$ acts as a complexating agent with the $\alpha$-amino and $\alpha$-carboxylate groups, thereby allowing the selective protection of the $\omega$-amino funcionality. ${ }^{138,139,140}$ Another alternative also based on complexation is the formation of boron complexes using $\mathrm{B}(\mathrm{Et})_{3}$ as the complexating agent. ${ }^{141}$

In some cases (e.g: Z), side chain protection can be achieved by protecting both the $\alpha$ amino and the $\omega$-amino funcionalities and then selectively deprotecting the former, taking advantage of their higher lability. ${ }^{142}$

\subsection{Removal}

\subsubsection{Protecting groups removed by acid}

-2-Chlorobenzyloxycarbonyl (Cl-Z). It is removed with HF or TFMSA and is preferentially used in the Boc/Bzl solid phase strategy over the $\mathrm{Z}$ group because $\mathrm{Cl}-\mathrm{Z}$ shows major resistance to the repetitive TFA treatments to remove Boc group. ${ }^{143}$ Both, $\mathrm{Z}$ and $\mathrm{Cl}-\mathrm{Z}$, are stable to bases and can be removed by hydrogenolysis in solution.

- tert-Butyloxycarbonyl (Boc). It is removed with 25-50\% TFA. ${ }^{144}$ It is used in the Fmoc/t $\mathrm{Bu}$ solid phase strategy and is resistant to bases and catalytic hydrogenation. 
- 4-Methyltrityl (Mtt). It can be used for temporary side chain protection in the Fmoc strategy and is a better option than Boc in the presence of sensitive amino acids such as Tyr, Met and Trp because it prevents side reactions during TFA cleavage because of the low electrophilicity of the bulky trityl cation. As expected, $\omega$-amino protection with Trttype groups is more stable than $\alpha$-amino protection. Removal of Mtt (4-methyltrityl) is performed selectively in the presence of Boc using 1\% TFA in DCM for 30 min or with AcOH-TFE-DCM (1:2:7) for $1 \mathrm{~h}{ }^{145}$ More acid-labile derivatives, like monomethoxytrityl (Mmt) and dimethoxytrityl (Dmt), are more convenient when hydrophilic resins (e.g. TentaGel) are used. ${ }^{146}$ 


\begin{tabular}{|c|c|c|c|}
\hline Name and Structure & $\begin{array}{l}\text { Removal } \\
\text { conditions }\end{array}$ & $\begin{array}{l}\text { Stability to the } \\
\text { removal of }\end{array}$ & Ref. \\
\hline 2-Chlorobenzyloxycarbonyl (Cl-Z) & $\begin{array}{l}\text { 1) } \mathrm{HF} \text {, scavengers } \\
\text { 2) TFMSA-TFA } \\
\text { 3) } \mathrm{H}_{2} \text { cat. }\end{array}$ & $\begin{array}{l}\text { Boc, Fmoc, Trt, } \\
\text { Alloc, } p \mathrm{NZ}^{\mathrm{a}}\end{array}$ & 143 \\
\hline tert-Butyloxycarbonyl (Boc) & $25-50 \%$ TFA-DCM & $\begin{array}{l}\text { Fmoc, } \mathrm{Z},{ }^{\mathrm{b}} \mathrm{Trt}, \\
\text { Alloc, } p \mathrm{NZ}\end{array}$ & 144 \\
\hline 4-Methyltrityl (Mtt) & $\begin{array}{l}\text { 1) } 1 \% \text { TFA-DCM } \\
\text { 2) AcOH-TFE- } \\
\text { DCM }(1: 2: 7)\end{array}$ & Fmoc, Alloc & 145,146 \\
\hline
\end{tabular}

${ }^{a}$ Except catalytical hydrogenation removal.

${ }^{\mathrm{b}}$ Catalytical hydrogenation removal.

\subsubsection{Protecting groups removed by base}

- 9-Fluorenylmethoxycarbonyl (Fmoc). ${ }^{141}$ See also $\alpha$-amino section. It is usually removed with $20 \%$ of piperidine in DMF or $1-5 \%$ DBU in DMF, its stability to acids makes it useful for the synthesis of cyclic and branched peptides using the Boc/Bn strategy. It is not completely stable to catalytic hydrogenation.

- 1-(4,4-Dimethyl-2,6-dioxocyclohex-1-ylidene)-3-mehtylbutyl (ivDde). ${ }^{147}$ It is useful as a temporary protecting group in the synthesis of cyclic and branched peptides. ${ }^{148}$ ivDde is an improved derivative of Dde (1-(4,4-dimethyl-2,6-dioxocyclohex-1-ylidene)-3ethyl), ${ }^{149,150,151}$ which is considerably less base-labile and therefore stable to Fmoc removal conditions and can be removed by hydrazinolysis. An additional advantage of ivDde is that its steric hindrance makes it is less prone to migrate to free Lys or Orn side chains (Figure 6). ${ }^{147}$ To prevent the reduction of the allyl group by hydrazine, allyl alcohol should be used when ivDde is removed in the presence of allyl-type protecting groups. ${ }^{152}$ 


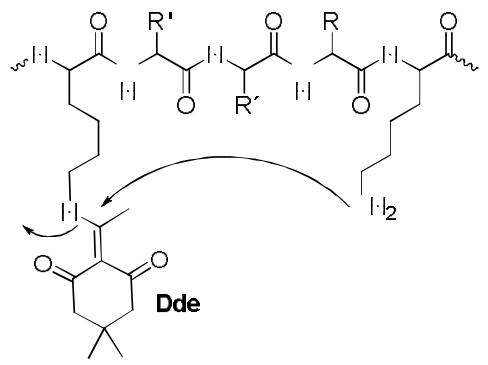

Figure 6. Dde $\mathrm{N} \rightarrow \mathrm{N}^{\prime}$ migration. This side reaction is prevented using ivDde.

- Trifluoroacetyl (tfa). ${ }^{153}$ It is removed by alkali treatment $(0.2 \mathrm{~N} \mathrm{NaOH}$ in $10 \mathrm{~min}),{ }^{154}$ aqueous piperidine ${ }^{155,156,157}$ or sodium borhydride. ${ }^{158}$ It is stable to strong acids and therefore compatible with the Boc strategy. The basic conditions used for its removal may promote aspartimide formation if aspartic residues are present or pyroglutamyl formation in the case of $\mathrm{N}$-terminal glutamine residues.

- 2-(Methylsulfonyl)ethoxycarbonyl (Msc) ${ }^{159}$ It is removed with $0.025-0.5 \mathrm{M} \mathrm{Ba}(\mathrm{OH})_{2}$, or the $4 \mathrm{~N} \mathrm{NaOH}_{(\mathrm{aq})}$-dioxane-MeOH (0.25:7.5:0.25). It is highly stable to acids (TFA rt and long reaction times, $\mathrm{HF} 0{ }^{\circ} \mathrm{C} 30 \mathrm{~min}, \mathrm{HCl}$ conc $40^{\circ} \mathrm{C} 1 \mathrm{~h}$ ) ${ }^{160}$ and hydrogenolysis. This reactivity allowed the use of $\omega$-protection with Msc in combination with Boc and Z $\alpha$-protection. ${ }^{161}$

Tetrachlorophthaloyl $(T C P) .{ }^{162}$ It is a relatively new protecting group proposed for SPPS and also used for $\alpha$-amino protection. TCP side chain protection is removed with ethylenediamine-DMF $(1: 200)$ at $40^{\circ} \mathrm{C}, 1 \mathrm{~h}$ in repetitive deprotections. Nevertheless, hydrazine-based removal used for $\alpha$-amino deprotection leads to a complex mixture of compounds. ${ }^{162}$ TCP is stable to Fmoc, Boc and Alloc removal conditions. 


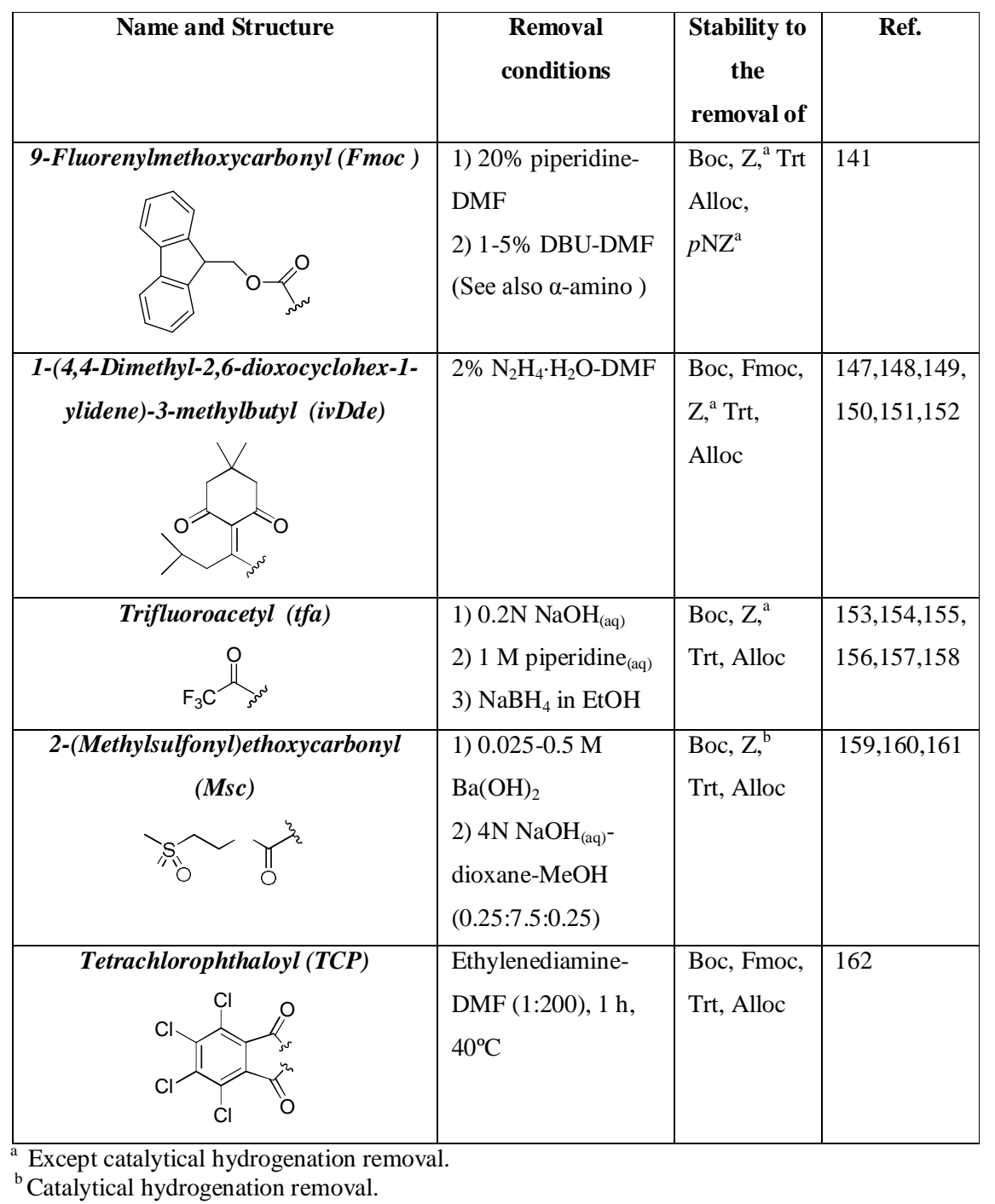

\subsubsection{Other protecting groups}

- Allyloxycarbonyl (Alloc). ${ }^{163,164,102}$ It is removed using a palladium catalyst in the presence of a scavenger to capture the generated carbocation. It is compatible with the $\mathrm{Boc} / \mathrm{Bn}$ and $\mathrm{Fmoc} /{ }^{t} \mathrm{Bu}$ strategies. See also $\alpha$-amino protection.

- 2-Chlorobenzyloxycarbonyl (Cl-Z). See protecting groups removed by acid.

- p-Nitrobenzyloxycarbonyl ( $p N Z$ ). See also $\alpha$-amino protection section for removal details and references. $p \mathrm{NZ}$ protection of the side chains of Lys and Orn prevents the undesired removal of the $\alpha$-Fmoc group after side chain deprotection. ${ }^{165,166}$

- 2-Nitrobenzyloxycarbonyl (oNZ). See $\alpha$-amino protection. 
- 6-Nitroveratryloxycarbonyl (NVOC). ${ }^{167}$ See $\alpha$-amino protection.

- Phenyldisulphanylethyloxycarbonyl (Phdec) and 2-Pyridyldisulphanylethyloxycarbonyl (Pydec). These are recently developed protecting groups which have been used either for solution or solid-phase synthesis. ${ }^{168}$ Both are removed by mild thiolysis using dithiothreitol (DTT) or $\beta$-mercaptoethanol in Tris. $\mathrm{HCl}$ buffer $(\mathrm{pH}$ 8.5-9.0) for deprotection in water or by treatment with $\beta$-mercaptoethanol and DBU in NMP for deprotection in an organic medium.

- o-Nitrobenzenesulfonyl (o-NBS). It is widely used for the $\alpha-N$-methylation of amino acids. Because of its high stability to acids and bases, $o$-NBS has found application in the side chain protection of secondary amines derived from Lys and Orn. It is removed from secondary amines by mercaptoethanol in the presence of DBU. ${ }^{169,170}$ 


\begin{tabular}{|c|c|c|c|}
\hline Name and Structure & Removal conditions & $\begin{array}{l}\text { Stability } \\
\text { to the } \\
\text { removal } \\
\text { of }\end{array}$ & Ref. \\
\hline Allyloxycarbonyl (Alloc) & $\begin{array}{l}\mathrm{Pd}(\mathrm{PPh})_{3} \text { cat., } \\
\text { scavengers: } \\
\mathrm{H}_{3} \mathrm{~N} \cdot \mathrm{BH}_{3}, \\
\mathrm{Me}_{2} \mathrm{NH} \cdot \mathrm{BH}_{3} \text { or } \\
\mathrm{PhSiH}_{3} \text { in organic } \\
\text { solvents }\end{array}$ & $\begin{array}{l}\text { Boc, } \\
\text { Fmoc, Trt, } \\
p \mathrm{NZ}^{\mathrm{a}}\end{array}$ & $102,163,164$ \\
\hline $\begin{array}{c}\text {-Nitrobenzyloxycarbonyl } \\
\qquad(p N Z) \\
0\end{array}$ & $\begin{array}{l}\text { 1) } 1-6 \mathrm{M} \mathrm{SnCl}_{2}, 1.6 \\
\mathrm{mM} \mathrm{HCl} \text { (dioxane) }-\mathrm{DMF} \\
\text { 2) } \mathrm{H}_{2} \text { cat } \\
\text { 3) } \mathrm{Na}_{2} \mathrm{~S}_{2} \mathrm{O}_{4}\end{array}$ & $\begin{array}{l}\text { Boc, } \\
\text { Fmoc, Z, } \\
\text { Trt, Alloc }\end{array}$ & 165,166 \\
\hline $\begin{array}{l}\text { Phenyldisulphanylethyloxycarbonyl } \\
\text { (Phdec) }\end{array}$ & $\begin{array}{l}\text { 1) DTT or } \beta- \\
\text { mercaptoethanol- } \\
\text { Tris·HCl buffer (pH } \\
8.5-9.0) \\
\text { 2) } \beta- \\
\text { mercaptoethanol, } \\
\text { DBU-NMP }\end{array}$ & $\begin{array}{l}\text { Boc, } \\
\text { Fmoc, Trt }\end{array}$ & 168 \\
\hline $\begin{array}{l}\text { 2-Pyridyldisulphanylethyloxycarbonyl } \\
\text { (Pydec) }\end{array}$ & $\begin{array}{l}\text { 1) DTT or } \beta- \\
\text { mercaptoethanol- } \\
\text { Tris. } \mathrm{HCl} \text { buffer (pH } \\
8.5-9.0) \\
\text { 2) } \beta- \\
\text { mercaptoethanol, } \\
\text { DBU-NMP }\end{array}$ & $\begin{array}{l}\text { Boc, } \\
\text { Fmoc, Trt }\end{array}$ & 168 \\
\hline $\begin{array}{c}\text { o-Nitrobenzenesulfonyl } \\
\text { (o-NBS) }\end{array}$ & $\begin{array}{l}\beta \text {-mercaptoethanol, } \\
\text { (5eq.) DBU (10 eq.)- } \\
\text { DMF }\end{array}$ & $\begin{array}{l}\text { Boc, } \\
\text { Fmoc, Trt }\end{array}$ & 169,170 \\
\hline
\end{tabular}

${ }^{\mathrm{a}}$ Except catalytical hydrogenation removal. 


\section{4. $\alpha$-CARBOXYLIC ACID}

\subsection{General}

The protection of the $C$-terminal carboxylic acid is different in SPS to in solution synthesis. In the former, the $C$-terminal is usually linked to the solid support and therefore the linker/handle acts as a protecting group. There are excellent reviews covering the linkers/handles used in SPPS and therefore they are out of the scope of the present review. Nevertheless, in some synthetic strategies where the peptide is linked to the resin by the backbone by an amino acid side chain, and also in the less frequent synthesis in the reverse $\mathrm{N}$ - $\mathrm{C}$ direction, ${ }^{38,171,172} \mathrm{C}$-terminal protection is required.

In the case of solution synthesis, $C$-terminal protection is not needed to form the peptide bond. However, in other cases $C$-terminal protection is mandatory.

\subsection{Introduction of the protecting groups ${ }^{173}$}

Protection of the $\alpha$-carboxylic acid can be performed mainly by the following methods.

- Reaction of a $\alpha$-amino free amino acid with an alcohol in acidic conditions $(\mathrm{HCl}$ and $p$-TosOH are the most used acids). ${ }^{174}$

- tert-Butyl protection by reaction of an $\alpha$-amino free or protected amino acid with isobutene in acidic conditions (usually $p$-Tos-OH or $\mathrm{H}_{2} \mathrm{SO}_{4}$ ). ${ }^{175,176}$

- Reaction of an $\alpha$-amino-protected amino acid in the presence of base or as a cessium salt with the corresponding halide (usually bromide). ${ }^{177,178}$

- Reaction of an $\alpha$-amino-protected amino acid with a condensating agent such as DCC in the presence of DMAP and the alcohol derivative of the protecting group. ${ }^{179}$

For the particular case of aspartic (Asp) and glutamic (Glu) acids $\alpha$-carboxyl protection, two main strategies are possible:

- Protection of the $\alpha$-carboxylic acid after selective protection of the side chain of $\mathrm{H}$ Asp-OH or H-Glu-OH either via acid catalyzed esterification or in the presence of a copper chelate (see protection of side chain of Asp and Glu). Side chain deprotection renders the desired protected derivative. ${ }^{180,181,141}$

- Selective protection of the $\alpha$-carboxylic acid via formation of an intramolecular anhydride between the two carboxylic acids and reaction with the corresponding alcohol or via reaction with a halide in the presence of base. In both cases, $N$-protected Asp or Glu acid are used as starting materials. In the first case, selective $\alpha$-protection is achieved as a result of the major electrophilicity of the $\alpha$-carboxylic acid, whereas in the second the selective protection is due to the major acidity of the $\alpha$-carboxylic acid. ${ }^{182,183}$ 


\subsection{Removal}

\subsubsection{Protecting groups removed by acid.}

- tert-Butyl $\left({ }^{t} B u\right) .{ }^{176}$ It is used in both solution- and solid-phase synthesis. It is removed with high concentrations of TFA (solid phase and solution) or $\mathrm{HCl}$ in organic solvents (solution). In the latter case, it is effectively used along with Bpoc $N^{\alpha--}$ protection and $\operatorname{Trt}$ side chain protection or with $\mathrm{Z}$ group as $N^{\alpha-}$ protection. It is stable to base-catalyzed hydrolysis and its bulkiness generally prevents DKP formation. ${ }^{184}$

- Benzyl (Bn): See "other protecting groups"

- 2-Chlorotrityl (2-Cl-Trt). ${ }^{185}$ It is removed with $1 \%$ TFA in DCM and is used as a semi-permanent protecting group for the synthesis of large peptides using a convergent approach.

- 2,4-Dimethoxybenzyl (Dmb). ${ }^{186}$ It is removed with $1 \%$ TFA in DCM (6 x 5 min). Due to its high acid lability, it can be removed in the presence of ${ }^{t} \mathrm{Bu}$-type protecting groups and also on Wang and PAL/Rink resins. It is used for Fmoc/tBu SPS of "head to tail" cyclic peptides.

- 2-Phenylisopropyl (2-Ph ${ }^{i}$ Pr). ${ }^{187}$ It is removed with 4\% TFA in DCM for 15 min (Boc group is stable to these conditions).

- 5-Phenyl-3,4-ethylenedioxythenyl derivatives (Phenyl-EDOTn). ${ }^{188}$ They have been recently developed and are removed using very small concentrations of TFA (0.01$0.5 \%$ ), being the most acid labile derivative the 5-(3,4-dimethoxyphenyl)-3,4ethylenedioxythenyl. 


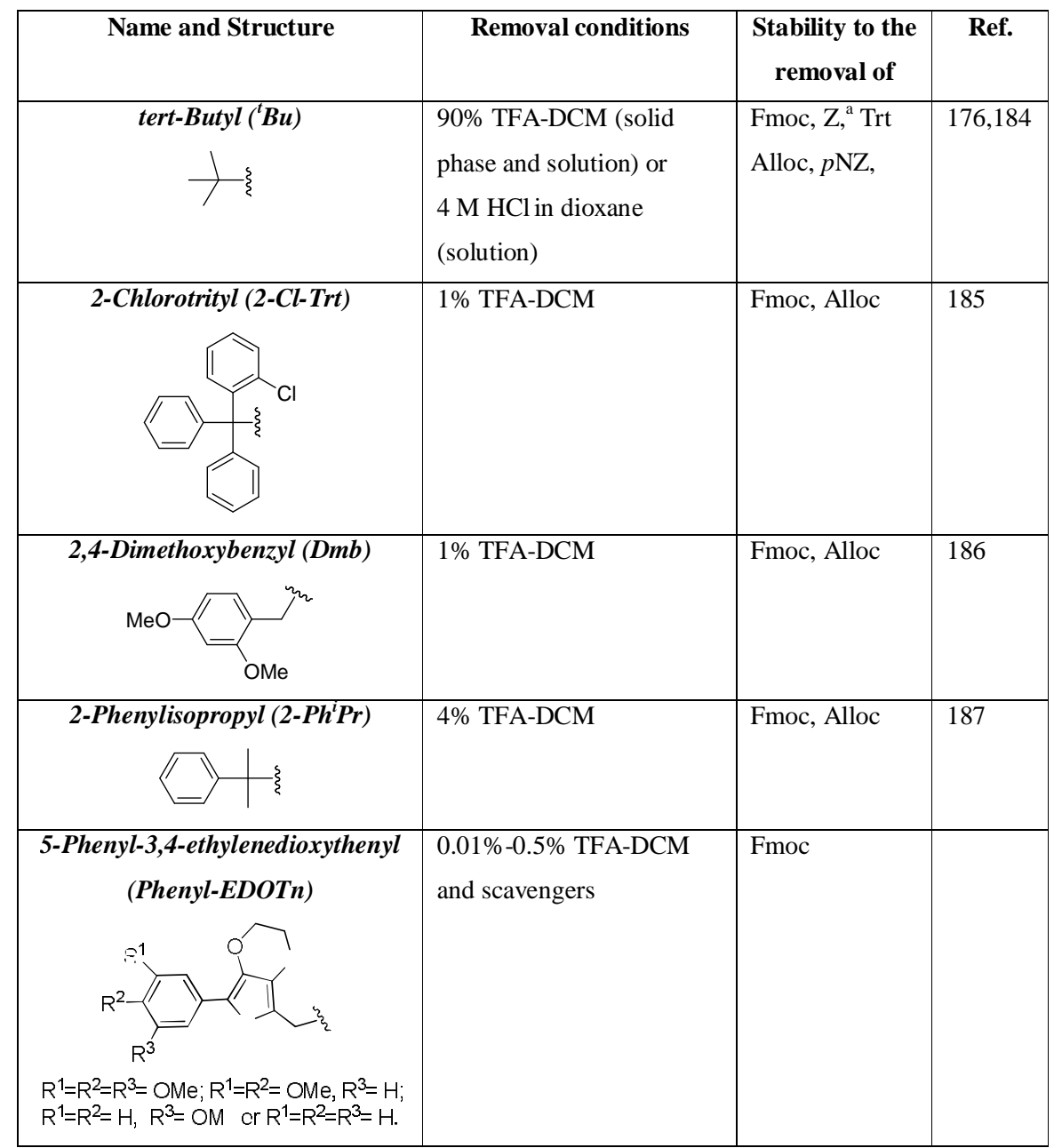

${ }^{\mathrm{a}}$ Catalytical hydrogenation removal.

\subsubsection{Protecting groups removed by base.}

- 9-Fluorenylmethyl (Fm). ${ }^{189,190}$ It is removed with secondary amines such as piperidine and DEA in DCM or DMF, and also by catalytical hydrogenation in solution. ${ }^{190}$ Used for SPS in the reverse $N-C$ direction, ${ }^{171}$ as well as for the preparation of "head to tail" cyclic peptides. ${ }^{191}$

- 4-(N-[1-(4,4-dimethyl-2,6-dioxocyclohexylidene)-3-methylbutyl]-amino)benzyl $(D m a b) .{ }^{192}$ It is removed by $2 \%$ of hydrazine $\cdot \mathrm{H}_{2} \mathrm{O}-\mathrm{DMF}(1: 1)$ within minutes. It is stable to piperidine.

- Methyl (Me) and Ethyl (Et). ${ }^{193}$ Methyl esters are removed by saponification (usually with $\mathrm{LiOH}$ ), which can lead to epimerization and degradtion of Ser, Cys and Thr. 
Nevertheless, they have been used extensively in classical peptide synthesis in solution. They are also a reasonable choice to obtain peptide amides by reaction of the methyl ester with ammonia. Ethyl esters have a similar behaviour to methyl esters but are more base-stable and therefore more prone to base- catalyzed side reactions. ${ }^{184}$

- Carbamoylmethyl (Cam). ${ }^{194,195}$ It is used for solution synthesis. It is removed by saponification with $\mathrm{NaOH}$ or $\mathrm{Na}_{2} \mathrm{CO}_{3}$ in DMF. It is removed selectively in the presence of Boc and Z. Nevertheless, it can not be selectively removed in the presence of side chain Bn-protected Asp.

\begin{tabular}{|c|c|c|c|}
\hline Name and Structure & Removal conditions & $\begin{array}{c}\text { Stability to the } \\
\text { removal of }\end{array}$ & Ref. \\
\hline 9-Fluorenylmethyl (Fm) & $\begin{array}{l}15 \% \text { DEA or } 20 \% \\
\text { piperidine-DMF or } \\
\text { DCM }\end{array}$ & Boc, Trt, Alloc & $\begin{array}{l}171, \\
189, \\
190, \\
191\end{array}$ \\
\hline $\begin{array}{c}\text { 4-(N-[1-(4,4-dimethyl-2,6- } \\
\text { dioxocyclohexylidene)-3-methylbutyl]- } \\
\text { amino)benzyl (Dmab) }\end{array}$ & $\begin{array}{l}2 \% \text { hydrazine- } \mathrm{H}_{2} \mathrm{O}- \\
\operatorname{DMF}(1: 1)\end{array}$ & Boc, Fmoc, Trt, & 192 \\
\hline Methyl (Me) and Ethyl (Et) & $\mathrm{LiOH}, \mathrm{NaOH}$ or $\mathrm{KOH}$ & Boc, $\mathrm{Z}$ & $\begin{array}{l}184, \\
193\end{array}$ \\
\hline $\begin{array}{c}\text { Carbamoylmethyl (Cam) } \\
\text { (C) }\end{array}$ & $\begin{array}{l}\mathrm{NaOH} \text { or } \mathrm{Na}_{2} \mathrm{CO}_{3^{-}} \\
\text {DMF- } \mathrm{H}_{2} \mathrm{O}\end{array}$ & Boc, Fmoc $^{a} Z^{b}$ & $\begin{array}{l}195, \\
194\end{array}$ \\
\hline
\end{tabular}

${ }^{\mathrm{a}}$ Diethylamine removal.

${ }^{\mathrm{b}}$ Only catalytical hydrogenation removal.

\subsubsection{Other protecting groups}

- Allyl (Al). ${ }^{163} \mathrm{It}$ is removed using $\mathrm{Pd}\left(\mathrm{PPh}_{3}\right)_{4}$ (0.1 eq.) and $\mathrm{PhSiH}_{3}$ (10 eq.) as scavenger in DCM within minutes or $\mathrm{Pd}\left(\mathrm{PPh}_{3}\right)_{4}$ and morpholine as nucleophile in THF-DMSO$0.5 \mathrm{M} \mathrm{HCl}$ (2:2:1), both on solid phase and in solution. ${ }^{196}$ If removed on solid phase, washings with sodium $N, N$-diethyldithiocarbamate $(0.02 \mathrm{M}$ in DMF, $3 \times 15 \mathrm{~min})$ are carried out in order to remove Pd. Allyl $C$-terminal protection has been used for the synthesis of $C$-terminal modified peptides using the backbone linker (BAL) strategy, ${ }^{38}$ 
and recently for the synthesis of peptide analogs where $\alpha$-carboxyl protection is necessary both in solution and on solid phase, such as the synthesis of cyclic peptides via head-to-tail cyclization, among others. ${ }^{197198,199,200,201}$ In these cases, when the $\mathrm{Al}$ group from the carboxyl group and the Fmoc from the amino group need to be removed, it is preferable to first remove the $\mathrm{Al}$ and then the Fmoc. Removal of the Fmoc group first could increase the risk of allylation of the amino function during the removal of the Al. ${ }^{200,202}$

- Benzyl (Bn). It is used mostly in solution synthesis. It is usually removed by catalytic hydrogenolysis. It can also be removed by saponification or hydrazinolysis to give the corresponding $C$-terminal. Acidolytic removal is also possible but harsh conditions are required. It is used in combination with the following $N^{\alpha}$-protecting groups: Boc, Ddz, Bpoc and Troc. ${ }^{184}$

- Phenacyl (Pac). ${ }^{203}$ It is used for synthesis in solution and removed by nucleophiles such as sodium thiophenoxyde or by treatment with $\mathrm{Zn}$ in $\mathrm{AcOH} .{ }^{203,204}$ It is degraded and only partially removed by catalytical hydrogenation. It is more electrophilic than the methyl ester, thereby making Pac-protected amino acids prone to racemization during coupling because of a reversible cyclization mechanism (Figure 7).

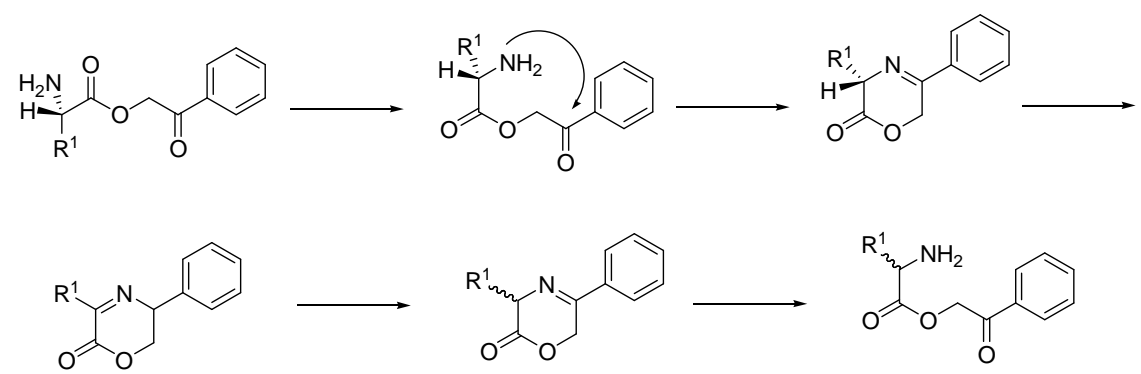

Figure 7. Racemization mechanism of Pac-protected amino acids. Adapted from 205

- $p$-Nitrobenzyl $(p N B)$. It is highly resistant to acids and removed using a variety of reducing agents such as $\mathrm{Na}_{2} \mathrm{~S}, \mathrm{Na}_{2} \mathrm{~S}_{2} \mathrm{O}_{4}, \mathrm{SnCl}_{2}$ or catalytical hydrogenation. ${ }^{206,207,208},{ }^{209}$ Solid phase removal is performed by treatment with $8 \mathrm{M} \mathrm{SnCl}_{2}$ in DMF containing 1.6 $\mathrm{mM} \mathrm{AcOH}$ and $0.2 \%$ phenol for $5 \mathrm{~h}$ at $25^{\circ} \mathrm{C}$ or three treatments of $30 \mathrm{~min}$ at $60^{\circ} \mathrm{C} .{ }^{210}$ Washings with DMF, MeOH, DMF and treatment with $8 M$ benzene sulfinic acid in DMF for 30 min at $25^{\circ} \mathrm{C}$ and further washings with DMF and $\mathrm{MeOH}$ are performed to eliminate the quinonimine methide formed during the removal. ${ }^{211}$ Use of a less concentrated and more easy to handle $6 \mathrm{M} \mathrm{SnCl}_{2}$ in DMF solution, substitution of 
$\mathrm{AcOH}$ by $\mathrm{HCl}$ in dioxane and alternative washings (DMF, DMF/ $\mathrm{H}_{2} \mathrm{O}, \mathrm{THF} / \mathrm{H}_{2} \mathrm{O}$, DMF and DCM, $3 \times 30 \mathrm{~s}$ each) have been described in the case of Glu side chain protection. ${ }^{165}$ These conditions should be easily adapted to the removal of the $C$-terminal protecting group. Removal with TBAF in solution has also been proposed as an alternative to the reductive removal. ${ }^{212}$

- 2-Trimethylsilylethyl (TMSE). ${ }^{213}$ It is removed with a quaternary ammonium fluoride such as TBAF or tetraethylammonium fluoride (TEAF) in DMF. It is stable to hydrogenolysis but unstable to anhydrous TFA. Nevertheless, Boc group can be removed selectively in its presence when $\mathrm{HCl}$ solutions in organic solvents are used.

- (2-Phenyl-2-trimethylsiylyl)ethyl (PTMSE). ${ }^{214,215}$ It is removed by treatment with TBAF. $3 \mathrm{H}_{2} \mathrm{O}$ in DCM in almost neutral conditions within 3-5 min. It is stable to the hydrogenolytic cleavage of $\mathrm{Z}$ and $\mathrm{Bn}$ ester groups, base-induced removal of Fmoc groups, palladium(0)-catalyzed removal of Alloc and even acidolytic cleavage of Boc groups if carried out under special conditions ( $p$ - $\mathrm{TsOH}$ or $1.2 \mathrm{M} \mathrm{HCl}$ in 2,2,2trifluoroethanol (TFE). PTMSE esters are also stable under the conditions for amide bond formation in peptide synthesis or peptide condensation reactions and therefore it is considered a valuable novel carboxy protecting group. However, no studies on how the use of PTMSE affects the formation of aspartimides have been performed to date.

- 2-(Trimethylsilyl)isopropyl (Tmsi). ${ }^{216}$ It is used for peptide synthesis in solution. It is removed with TBAF (8 eq.) in THF in 1-1.5 h. It significantly reduces DKP formation in comparison with TMSE.

- 2,2,2-Trichloroethyl (Tce). ${ }^{217}$ It is used mainly for solution synthesis. It is removed with $\mathrm{Zn}$ dust in $\mathrm{AcOH}$ in similar conditions as Troc and therefore can be removed in the presence of Z, Boc, Alloc and Fmoc. Tce is stable even at pH 1 and therefore Boc can be removed selectively in its presence. It is not completely stable to hydrogenolysis.

- $p$-Hydroxyphenacyl $(p H P) .{ }^{218}$ It is removed by photolysis $(\lambda=337 \mathrm{~nm})$ and used as a new phototrigger. It is stable to Boc removal.

4,5-Dimethoxy-2-nitrobenzyl (Dmnb). ${ }^{219}$ It is a photolabile protecting group analogous to the NVOC group. It has been used for the synthesis of misacylated transfer RNAs, and recently for the synthesis of caged peptides. ${ }^{220}$

- 1,1-Dimethylallyl (Dma). ${ }^{221}$ It is removed by treatment with $\mathrm{Pd}\left(\mathrm{PPh}_{3}\right)_{4}(10 \mathrm{~mol} \%)$ in THF at room temperature followed by dropwise addition of NMM (3 eq.) under nitrogen. $\mathrm{PhSiH}_{3}$, potassium 2-ethyl hexanoate or $p$-toluene sulfonic acid sodium salt 
can be used instead of NMM. It is orthogonal to the Fmoc group and can be removed in the presence of $\mathrm{Bn}$ - and ${ }^{t} \mathrm{Bu}$-type groups but it is not stable to their acidolitic removal. - Pentaamine cobalt (III). ${ }^{222}$ It was proposed as a $C$-terminal-protecting group for the synthesis of side chain to side chain bicyclic peptides. It is described as orthogonal to Fmoc and Boc and is removed in solution by mild reduction with DTT in the presence of DIPEA in $\mathrm{H}_{2} \mathrm{O}-\mathrm{AcCN}$ to the exchange labile $\mathrm{Co}$ (II) form. It has not been widely used since then.

\begin{tabular}{|c|c|c|c|}
\hline Name and Structure & Removal conditions & $\begin{array}{l}\text { Stability to the } \\
\text { removal of }\end{array}$ & Ref. \\
\hline $\operatorname{Allyl}(A l)$ & $\begin{array}{l}\mathrm{Pd}\left(\mathrm{Ph}_{3}\right)_{4}(0.1 \text { eq.) and } \\
\text { scavengers (usually } \\
\mathrm{PhSiH}_{3,} 10 \text { eq.)-DCM }\end{array}$ & $\begin{array}{l}\text { Boc, Fmoc, } \\
p N Z,{ }^{a} \text { Trt }\end{array}$ & $\begin{array}{l}38,163, \\
196,197, \\
198,199, \\
200,201, \\
202\end{array}$ \\
\hline Benzyl (Bn) & $\begin{array}{l}\text { 1) } \mathrm{HF} \\
\text { 2) } \mathrm{TFMSA} \\
\text { 3) } \mathrm{H}_{2} \text { cat. } \\
\text { 4) } \mathrm{NaOH} \text { in aqueous } \\
\text { organic solvents }\end{array}$ & $\begin{array}{l}\text { Boc, }{ }^{\mathrm{b}} \text { Fmoc, } \\
p \mathrm{NZ},{ }^{\mathrm{a}} \text { Trt, Alloc }\end{array}$ & 184 \\
\hline $\begin{array}{c}\text { Phenacyl(Pac) } \\
\circ\end{array}$ & $\begin{array}{l}\text { 1) sodium } \\
\text { thiophenoxyde } \\
\text { 2) } \mathrm{Zn} \text { in } \mathrm{AcOH}\end{array}$ & Boc, $Z$, ${ }^{\mathrm{a}}$ Trt & 203,204 \\
\hline p-Nitrobenzyl (pNB) & $\begin{array}{l}\text { 1) } \mathrm{SnCl}_{2} \text { in DMF } \\
\text { 2) } \mathrm{Na}_{2} \mathrm{~S} \cdot 9 \mathrm{H}_{2} \mathrm{O}-\mathrm{H}_{2} \mathrm{O} \text {, } \\
0-5^{\circ} \mathrm{C} \\
\text { 3) } \mathrm{Na}_{2} \mathrm{~S}_{2} \mathrm{O}_{4}, \mathrm{Na}_{2} \mathrm{CO}_{3}- \\
\mathrm{H}_{2} \mathrm{O}, 40^{\circ} \mathrm{C} \\
\text { 4) } \mathrm{H}_{2} \text { cat. } \\
\text { 5) TBAF-THF, DMF } \\
\text { or DMSO }\end{array}$ & $\begin{array}{l}\text { Boc,Fmoc, Z, } \\
\text { Trt, Alloc }\end{array}$ & $\begin{array}{l}165,206 \\
207,208, \\
209,210, \\
212\end{array}$ \\
\hline 2-Trimethylsilylethyl (TMSE) & TBAF or TEAF-DMF & $Z^{c}$ & 213 \\
\hline $\begin{array}{c}\text { (2-Phenyl-2-trimethylsilyl)ethyl } \\
\text { (PTMSE) }\end{array}$ & TBAF-3 $\mathrm{H}_{2} \mathrm{O}-\mathrm{DCM}$ & Fmoc, Z, ${ }^{\mathrm{c}}$ Alloc & 214,215 \\
\hline
\end{tabular}




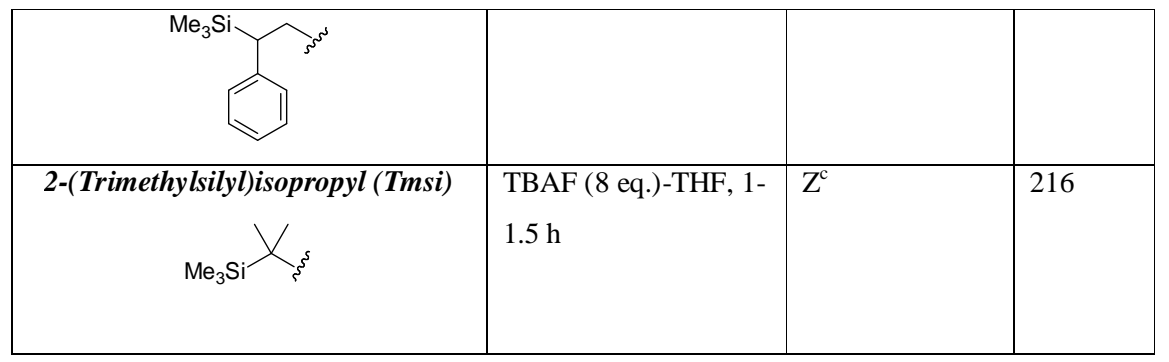

\begin{tabular}{|c|c|c|c|}
\hline 2,2,2-Trichloroethyl (Tce) & $\mathrm{Zn}$ dust-AcOH & Boc, Fmoc, Trt & 217 \\
\hline p-Hydroxyphenacyl (pHP) & $\begin{array}{l}\text { Photolysis } \\
(\lambda=337 \mathrm{~nm})\end{array}$ & Boc, Trt & 218 \\
\hline $\begin{array}{c}\text { 4,5-Dimethoxy-2-nitrobenzyl } \\
(\text { Dmnb })\end{array}$ & $\begin{array}{l}\text { Photolysis } \\
(\lambda>320 \mathrm{~nm})\end{array}$ & Boc, Fmoc, Trt & 219,220 \\
\hline 1,1-Dimethylallyl (Dma) & $\begin{array}{l}\mathrm{Pd}\left(\mathrm{PPh}_{3}\right)_{4} \text { and } \\
\text { scavengers: NMM, } \\
\mathrm{PhSiH}_{3} \text {, potassium 2- } \\
\text { ethyl hexanoate or } p \text { - } \\
\text { Tos-OK-THF }\end{array}$ & Fmoc & 221 \\
\hline $\begin{array}{l}\text { Pentaamine cobalt (III) } \\
\qquad \xi-\mathrm{Co}(\mathrm{NH})_{5} \cdot \mathrm{Cl}_{2}\end{array}$ & $\begin{array}{l}\text { DTT, DIPEA- } \mathrm{H}_{2} \mathrm{O}- \\
\text { AcCN }\end{array}$ & Boc, Fmoc, Trt & 222 \\
\hline
\end{tabular}

${ }^{a}$ Except catalytical hydrogenation removal.

${ }^{\mathrm{b}}$ Except repetitive removals.

${ }^{\mathrm{c}}$ Catalytical hydrogenation removal. 


\section{ASPARTIC (Asp) AND GLUTAMIC (Glu) ACIDS}

\subsection{General}

The side chain carboxylic groups of Asp and Glu (Figure 8) must be protected in order to prevent their activation during peptide synthesis, which would lead to undesired branched peptides.<smiles>N[C@@H](CC(=O)O)C(=O)O</smiles>

Asp<smiles>NC(CCC(=O)O)C(=O)O</smiles>

Glu

Figure 8. Aspartic (Asp) and Glutamic (Glu) acids.

Furthermore, in the case of Asp acid, the protecting groups used must also prevent or at least minimize the formation of aspartimide. Hydrolysis of the aspartimide during peptide synthesis renders two products: the $\alpha$-peptide, which is the desired product, and the $\beta$-peptide, which is usally the major compound. Aminolysis of aspartimide by piperidine gives the corresponding $\alpha$ - and $\beta$-piperidides (Figure 9).

The same kind of intramolecular cyclization can also take place in the case of Glu, thereby leading to pyroglutamic formation. ${ }^{223}$ However, in the case of Glu the reaction is much less severe than with Asp.

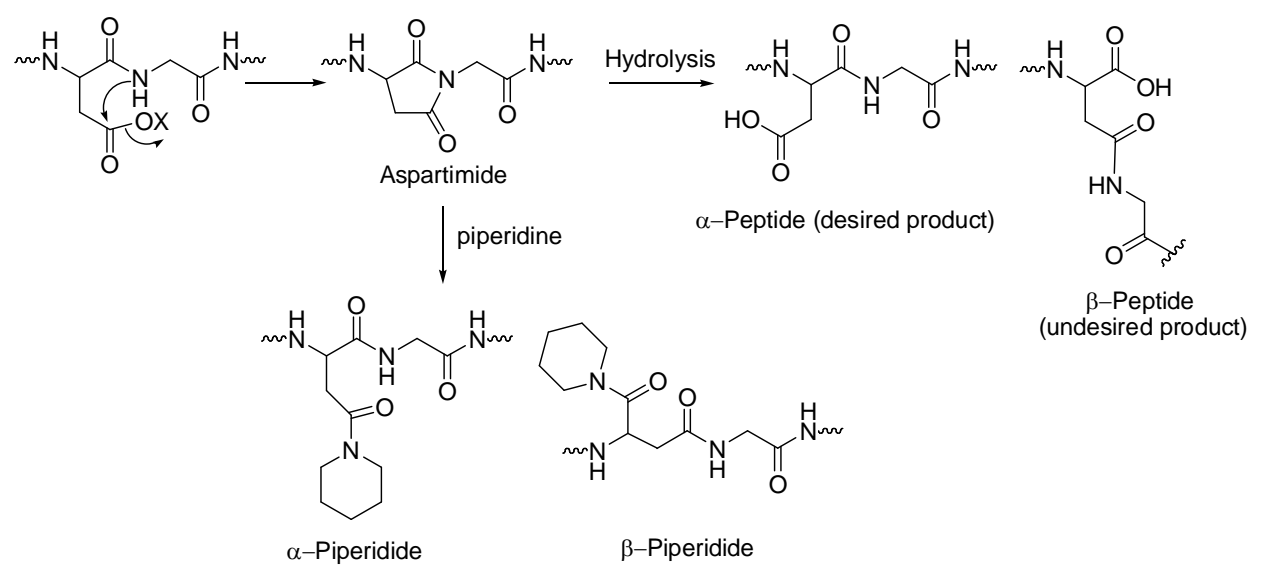

Figure 9. Aspartimide formation followed by piperidide formation upon piperidine treatment or hydrolysis rendering the $\alpha$ - and $\beta$-peptides. 
Currently the most used protecting groups are ${ }^{t} \mathrm{Bu}$ for the $\mathrm{Fmoc} /{ }^{t} \mathrm{Bu}$ strategy, and in the $\mathrm{Boc} / \mathrm{Bn}$ strategy the cyclohexyl $(c \mathrm{Hx})$ group, which is replacing the classical $\mathrm{Bn}$ group because it is more effective at preventing the formation of aspartimide.

\subsection{Introduction of the protecting groups}

The protection of the side chain carboxylic acid can be achieved using several methods. The simplest one is the acid-catalyzed esterification of the free amino acid, where protonation of the amino group makes the $\alpha$-carboxylic acid less reactive, thereby allowing the selective protection of the side chain. ${ }^{224,225}$

Copper (II) and boron chelates used for the selective protection of the side chains of Lys and Orn are also applied for the selective protection of the side chain of Asp and Glu. After chelation and reaction with the appropiate protecting group halide, the chelate is removed in the usual way. ${ }^{180,181,141}$ Another alternative is the formation of an intramolecular anhydride between the two carboxylic acids, which leads to selective $\alpha$ protection thanks to the major electrophilicity of the $\alpha$-carboxylic acid. This allows the protection of the side chain with a distinct protecting group, followed by the removal of the $\alpha$-carboxylic acid protection. ${ }^{174,175}$

\subsection{Removal}

\subsubsection{Protecting groups removed by acid}

- Benzyl (Bn). It is the classical protecting group in Boc/Bn chemistry and is removed with HF or TFMSA. However, it is more prone to acid-catalyzed aspartimide formation than the cyclohexyl group. Other possible removal conditions are listed in the table.

- Cyclohexyl $(c H x)$. It is removed with HF or TFMSA. ${ }^{226} 227$ It is widely used in the Boc/Bn solid- phase strategy. It is superior to the benzyl group at preventing acidcatalyzed aspartimide formation because of its major steric hindrance. ${ }^{228}$ In addition, it is more resistant to acids than benzyl, thus making it more suitable for the synthesis of long peptides using the Boc/Bn strategy.

- tert-Butyl $\left({ }^{t} B u\right)$. It is removed with 90\% TFA in DCM (solid phase and solution) or 4 $\mathrm{M} \mathrm{HCl}$ in dioxane(solution). It is the most used protecting group in $\mathrm{Fmoc} / \mathrm{t} \mathrm{Bu}$ chemistry, which is highly prone to aspartimide formation because of the reiterative use of piperidine. The ${ }^{t} \mathrm{Bu}$ group simply minimizes aspartimide formation because of its steric hindrance compared to other less hindered protecting groups such as allyl. However, although the ${ }^{t} \mathrm{Bu}$ group is considered hindered in organic chemistry, it does not prevent aspartimide formation in those sequences prone to it. ${ }^{229}$ See also $\alpha$-amino protection. 
- $\beta$-Menthyl (Men). ${ }^{230}$ It is removed with HF or TFMSA and is resistant to TFA. It leads to less base-catalyzed aspartimides than the cyclohexyl group, but is not widely used. Sometimes diphenyl sulfide should be added as a scavenger to facilitate Men removal. 231

- $\beta$-3-Methylpent-3-yl (Mpe). ${ }^{232}$ It is removed with $95 \%$ TFA and is more sterically hindered than the ${ }^{t} \mathrm{Bu}$ group and therefore less prone to aspartimide formation.

- 2-Phenylisopropyl (2-Ph $\left.{ }^{i} \mathrm{Pr}\right)$. It is removed with $1-2 \% \mathrm{TFA}^{233,187}$ It is used in the Fmoc/t'Bu strategy mostly for the protection of Glu but also of Asp. ${ }^{234}$ It can be removed in the presence of ${ }^{t} \mathrm{Bu}$-type protecting groups and therefore it is useful for the preparation of cyclic peptides. ${ }^{235}$

- 4-(3,6,9-trioxadecyl)oxybenzyl (TEGBz or TEGBn). ${ }^{236}$ It is a recently developed protecting group which is removed with TFA-DCM. It has been used for the solid phase synthesis of "difficult" peptide sequences (those very prone to aggregate) because it minimizes chain aggregation during the synthesis.

\begin{tabular}{|c|c|c|c|}
\hline Name and Structure & Removal conditions & $\begin{array}{l}\text { Stability to the } \\
\text { removal of }\end{array}$ & Ref. \\
\hline Benzyl (Bn) & $\begin{array}{l}\text { 1) } \mathrm{HF} \\
\text { 2) } \mathrm{TFMSA} \\
\text { 3) } \mathrm{H}_{2} \text { cat. } \\
\text { 4) } \mathrm{NaOH} \text { in aqueous } \\
\text { organic solvents }\end{array}$ & $\begin{array}{l}\text { Boc, Fmoc, } \\
p \mathrm{NZ},{ }^{\mathrm{a}} \mathrm{Trt}, \\
\text { Alloc, }\end{array}$ & \\
\hline Cyclohexyl (cHx) & $\begin{array}{l}\text { 1) } \mathrm{HF} \\
\text { 2) } \mathrm{TFMSA}\end{array}$ & $\begin{array}{l}\text { Boc, Fmoc, } \\
p \text { NZ, Trt, Alloc }\end{array}$ & $\begin{array}{l}227 \\
228\end{array}$ \\
\hline $\begin{array}{c}\text { tert-Butyl }\left({ }^{t} \mathrm{Bu}\right) \\
\quad \sum \xi\end{array}$ & $\begin{array}{l}90 \% \text { TFA-DCM (solid } \\
\text { phase and solution) or } \\
4 \mathrm{M} \mathrm{HCl}_{\text {(dioxane) }} \\
\text { (solution) }\end{array}$ & $\begin{array}{l}\text { Fmoc, } \mathrm{Z}^{\mathrm{b}} \mathrm{Trt} \\
\text { Alloc, } p \mathrm{NZ}\end{array}$ & 229 \\
\hline ק-Menthyl(Men) & HF, TFMSA-TFA & $\begin{array}{l}\text { Boc, Fmoc, Trt, } \\
\text { Alloc, } p \mathrm{NZ}\end{array}$ & $\begin{array}{l}230, \\
231\end{array}$ \\
\hline $\begin{array}{c}\beta-3-M e t h y l p e n t-3-y l(M p e) \\
y^{2}\end{array}$ & $95 \%$ TFA- $\mathrm{H}_{2} \mathrm{O}$ & $\begin{array}{l}\text { Fmoc, Z, }{ }^{\mathrm{b}} \mathrm{Trt}, \\
\text { Alloc }\end{array}$ & 232 \\
\hline 2-Phenylisopropyl (2-Ph $\left.{ }^{i} \mathrm{Pr}\right)$ & $1-2 \%$ TFA-DCM & Fmoc, Alloc & 187 , \\
\hline
\end{tabular}




\begin{tabular}{|c|c|c|c|}
\hline U1 & & & $\begin{array}{l}233, \\
234, \\
235\end{array}$ \\
\hline $\begin{array}{l}\text { 4-(3,6,9-trioxadecyl)oxybenzyl (TEGBz } \\
\text { or TEGBn) }\end{array}$ & TFA-DCM & Fmoc, Trt & \\
\hline
\end{tabular}

${ }^{\mathrm{a}}$ Except catalytic hydrogenation removal.

${ }^{\mathrm{b}}$ Only catalytic hydrogenation removal. 


\subsubsection{Protecting groups removed by base}

- 9-Fluorenylmethyl $(\mathrm{Fm}) .{ }^{141,237,238}$ It is removed with secondary amines such as diethylamine or piperidine in DMF. It is stable to $\mathrm{HBr}$ in $\mathrm{AcOH}$ and TFA/thioanisole and non-stable to catalytic hydrogenation and not completely stable to $\mathrm{HF}$ even at $0^{\circ} \mathrm{C}$. It is used for the Boc/Bn strategy when orthogonal protection of the side chains is required.

4-(N-[1-(4,4-Dimethyl-2,6-dioxocyclohexylidene)-3-methylbutyl]-amino)benzyl (Dmab) ${ }^{192,239}$ It is removed with $2 \%$ hydrazine within minutes in DMF- $\mathrm{H}_{2} \mathrm{O}$. It is stable to $20 \%$ piperidine in DMF and TFA. Nevertheless, in some cases it can lead to pyroglutamyl-terminated peptides. ${ }^{240}$

\begin{tabular}{|c|c|c|c|}
\hline Name and Structure & Removal conditions & $\begin{array}{l}\text { Stability to the } \\
\text { removal of }\end{array}$ & Ref. \\
\hline 9-Flurorenylmethyl $(\mathrm{Fm})$ & $\begin{array}{l}\text { Secondary amines: } \\
15 \% \text { DEA or } 20 \% \\
\text { piperidine-DMF or } \\
\text { DCM }\end{array}$ & Boc, Trt, Alloc & $\begin{array}{l}141, \\
237 \\
238\end{array}$ \\
\hline $\begin{array}{c}\text { 4-(N-[1-(4,4-dimethyl-2,6- } \\
\text { dioxocyclohexylidene)-3-methylbutyl]- } \\
\text { amino)benzyl (Dmab) }\end{array}$ & $\begin{array}{l}2 \% \text { hydrazine-DMF- } \\
\mathrm{H}_{2} \mathrm{O}\end{array}$ & $\begin{array}{l}\text { Boc, Fmoc, } \\
\text { Trt, Alloc }\end{array}$ & $\begin{array}{l}192, \\
239, \\
240\end{array}$ \\
\hline
\end{tabular}

\subsubsection{Other protecting groups}

- Benzyl (Bn). See protecting groups removed by acid.

- Allyl (Al). ${ }^{163,164,241}$ It is removed with palladium and stable to TFA and bases. See also $\alpha$-carboxylic acid protection.

- $p$-Nitrobenzyl $(p N B) .{ }^{242}$ It promotes aspartimide formation when used to protect Asp. See also $\alpha$-carboxylic acid protection.

- 2-(Trimethylsilyl)ethyl (TMSE). ${ }^{213,243}$ It is removed with fluorides, and is unstable to acids and bases, and stable to hydrogenolysis. It is used for the protection of Asp acid for cyclization on a Rink amide resin. ${ }^{244}$

- (2-Phenyl-2-trimethylsiylyl)ethyl (PTMSE). See $\alpha$-carboxylic acid protection. 
- 4,5-Dimethoxy-2-nitrobenzyl (Dmnb). See $\alpha$-carboxylic acid protection.

\begin{tabular}{|c|c|c|c|}
\hline Name and Structure & Removal conditions & $\begin{array}{c}\text { Stability to the } \\
\text { removal of }\end{array}$ & Ref. \\
\hline $\operatorname{Allyl}(A l)$ & $\begin{array}{l}\mathrm{Pd}\left(\mathrm{Ph}_{3}\right)_{4}(0.1 \text { eq. }) \text { and } \\
\text { scavengers (usually } \\
\left.\mathrm{PhSiH}_{3}, 10 \text { eq. }\right) \text { in } \\
\mathrm{DCM}\end{array}$ & $\begin{array}{l}\text { Boc, Fmoc, } \\
p N Z,{ }^{\mathrm{a}} \text { Trt }\end{array}$ & $\begin{array}{l}163 \\
164 \\
241\end{array}$ \\
\hline p-Nitrobenzyl $(p N B)$ & $\begin{array}{l}\text { 1) } \mathrm{SnCl}_{2} \text { in DMF } \\
\text { 2) } \mathrm{Na}_{2} \mathrm{~S} \cdot 9 \mathrm{H}_{2} \mathrm{O} \text { in } \mathrm{H}_{2} \mathrm{O} \text {, } \\
0-5^{\circ} \mathrm{C} \\
\text { 3) } \mathrm{Na}_{2} \mathrm{~S}_{2} \mathrm{O}_{4}, \mathrm{Na}_{2} \mathrm{CO}_{3} \\
\text { in } \mathrm{H}_{2} \mathrm{O}, 40^{\circ} \mathrm{C} \\
\text { 4) } \mathrm{H}_{2} \text { cat. } \\
\text { 5) TBAF-THF, DMF } \\
\text { or DMSO }\end{array}$ & $\begin{array}{l}\text { Boc,Fmoc, Z, } \\
\text { Trt, Alloc }\end{array}$ & 242 \\
\hline $\begin{array}{c}\text { Trimethylsilylethyl (TMSE) } \\
\mathrm{Me}_{3} \mathrm{Si} \sim{ }_{2}\end{array}$ & TBAF or TEAF-DMF & $\mathrm{Z}^{\mathrm{b}}$ & $\begin{array}{l}213 \\
243 \\
244\end{array}$ \\
\hline $\begin{array}{c}\text { (2-Phenyl-2-trimethylsilyl)ethyl } \\
\text { (PTMSE) }\end{array}$ & TBAF· $3 \mathrm{H}_{2} \mathrm{O}-\mathrm{DCM}$ & $\begin{array}{l}\text { Fmoc, Z, } \\
\text { Alloc }\end{array}$ & \\
\hline $\begin{array}{l}\text { 4,5-Dimethoxy-2-nitrobenzyloxycarbonyl } \\
\text { (Dmnb) }\end{array}$ & Photolysis $(\lambda>320 \mathrm{~nm})$ & Boc, Trt & \\
\hline
\end{tabular}

${ }^{\mathrm{a}}$ Except catalytical hydrogenation removal.

${ }^{\mathrm{b}}$ Catalytical hydrogenation removal. 


\section{AMIDE BACKBONE}

\subsection{General}

The NH backbone is usually unprotected in peptide synthesis. However, at least three undesired interactions involving the NH backbone have been described.

First of all, peptide chains can aggregate during the synthesis as a result of intra- and inter-molecular interactions, thereby significantly reducing coupling and deprotection yields. ${ }^{245,246,247}$ Backbone protection (Figure 10) minimizes these aggregation phenomena by preventing the formation of hydrogen bonds and also because of steric hindrance. Thus, SPS of long peptidic sequences prone to aggregation is improved by protecting some amides of the peptide. ${ }^{248,249,250,251}$

Secondly, nucleophilic attack of the amide NH of the amino acid before an Asp residue (usually Gly, Ser or Thr) ${ }^{69,227,62,252,253,254,255}$ to the $\beta$-carboxyl group of Asp renders aspartimide and the subsequent formation of $\beta$-peptide and other side products. (See Asp and Glu side chain protection). Aspartimide formation is more severe in the Fmoc/t'Bu strategy and with the Asp-Gly sequence but it can occur in many other cases. Finally, although less frequent, internal DKP formation involving the $\mathrm{NH}$ and the activated carboxylic acid of the previous amino acid has recently been described during fragment coupling (Figure 11) ${ }^{121}$

The most used backbone protectors for the $\mathrm{Fmoc} / \mathrm{Bu}$ strategy are pseudoprolines (Figure 12), ${ }^{256,257,251}$ 2-hydroxy-4-methoxybenzyl (Hmb), ${ }^{258}$ and 2,4-dimethoxybenzyl (Dmb), and more recently 3,4-ethylenedioxy-2-thenyl (EDOTn) and 1-methyl-3indolylmethyl (MIM) ${ }^{259}$ The pseudoproline concept is valid only for $\beta$-hydroxy or thio amino acids such as Ser/Thr or Cys. Although, the rest of protecting groups can be used for all amino acids, practically they are only used for Gly because of the difficulty of elongation of the peptide chain because of steric hindrance ${ }^{260}$

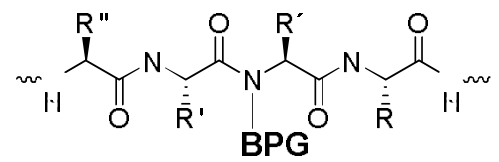

Figure 10. Partially backbone-protected peptide. $\mathrm{BPG}=$ backbone-protecting group 


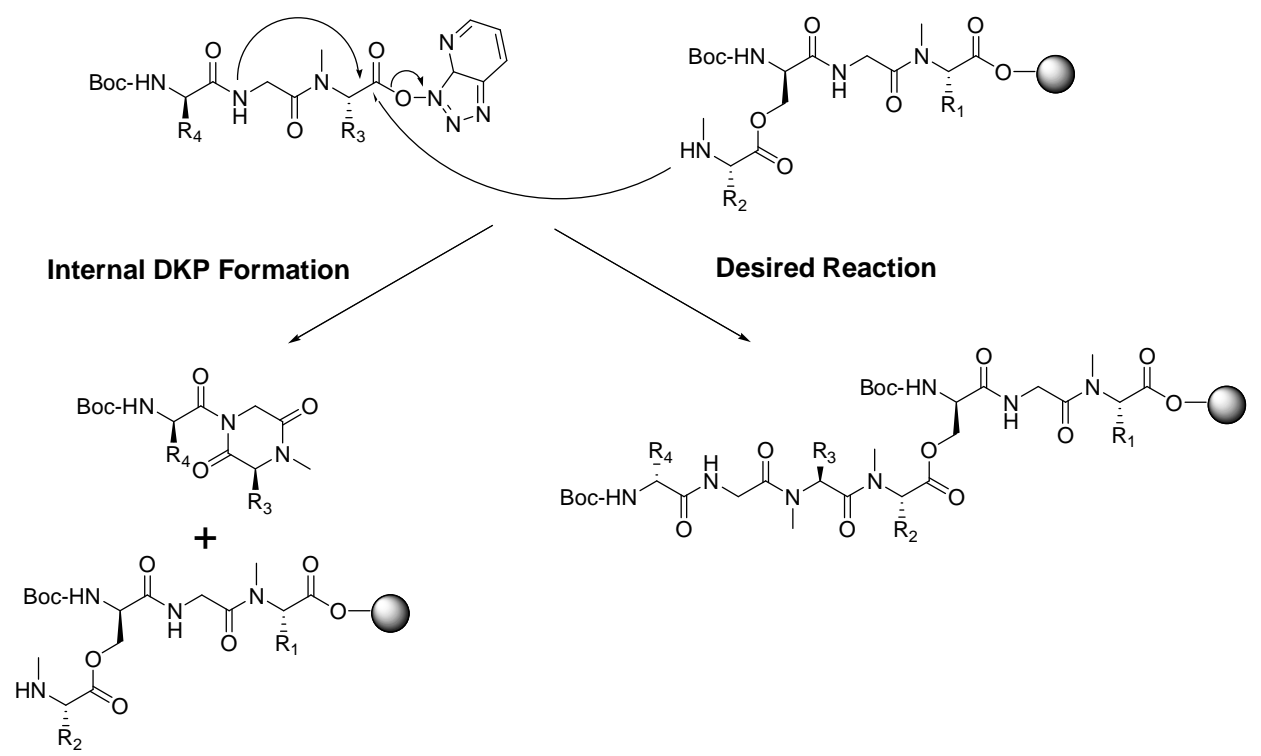

Figure 11. Internal DKP formation. Adapted from ref. 121<smiles>[R]C1OC(C)(C)NC1C(=O)O</smiles>

Figure 12. Pseudoproline of $\operatorname{Ser}(\mathrm{R}=\mathrm{H})$ and $\mathrm{Thr}\left(\mathrm{R}=\mathrm{CH}_{3}\right)$.

\subsection{Introduction of the protecting groups}

Due to the steric hindrance of the protected amino acid, it is incorporated usually through the corresponding dipeptides. Thus, pseudoproline dipeptides are prepared by reaction of Fmoc-AA-Ser or Fmoc-AA-Thr with 2,2-dimethoxypropane. ${ }^{261}$ Most of the other backbone protectors are introduced by reductive amination of the aldehyde of the protecting group with the amine of the corresponding amino acid, followed by either $\alpha$ amino protection or dipeptide formation. ${ }^{262,258,259}$

\subsection{Removal}

\subsubsection{Protecting groups removed by acid}

- Pseudoprolines (YPro). The most used are dimethyloxazolidines ( $\Psi^{\mathrm{Me}, \mathrm{Me}}$ pro) because of their major acid lability (removed by TFA within minutes) ${ }^{261}$ Pseudoproline derivatives have been extensively applied to the synthesis of difficult peptides. ${ }^{257,263}$ However, they are limited to Ser and Thr. Dimethylthiazolidines (Cys pseudoprolines) 
have also been described but they are not so widely used because of their major acid stability (removed with TFA within hours).

- 2-Hydroxy-4-methoxybenzyl (Hmb). ${ }^{258}$ It is used mainly as Fmoc-(FmocHmb)AA1$\mathrm{OH}^{264}$ or as Fmoc-AA2-(Hmb)AA1-OH but also as Fmoc(Hmb)AA1-OH. ${ }^{265}$ It is removed with TFA. The main advantage of the Hmb group compared with other backbone protectors such as Dmb is that the coupling on Hmb-amino acids is easier. Thus, Hmb is not restricted to Gly, and derivatives of more hindered amino acids can be used. However, the presence of a free hydroxyl group can be a problem in depsipeptide synthesis or in post-synthetic phosphorylations.

- 2,4-Dimethoxybenzyl $(\mathrm{Dmb}) .{ }^{266}$. It is removed with high concentrations of TFA. Its major inconvenience is its bulkiness, which limits its use for non-sterically hindered amino acids (mainly Gly), ${ }^{255}$ or for direct coupling of Dmb-protected dipeptides (Fmoc$\mathrm{AA}^{\prime}$-(Dmb)AA-OH). ${ }^{267}$

- 2,4,6-Trimethoxybenzyl (Tmob). ${ }^{268}$ It is removed with TFA and has been used for the Fmoc $/{ }^{t} \mathrm{Bu}$ SPS of highly hydrophobic peptides. ${ }^{269}$ Although it is not as widely used as Dmb, coupling on 2,4,6-trimethoxybenzyl amines of amino acids is described to be faster than in the case of the less hindered 2,4-dimethoxybenzyl amines. ${ }^{258}$

- 1-Methyl-3-indolylmethyl (MIM) and 3,4-Ethylenedioxy-2-thenyl $\left(E D O T_{n}\right){ }^{259}$ These are recently developed backbone protectors for the Fmoc/tBu strategy. They are completely removed with TFA-DCM- $\mathrm{H}_{2} \mathrm{O}(95-2.5-2.5)$ in $1 \mathrm{~h}$. Both are more acid-labile than the 2,4-dimethoxybenzyl group, and $\mathrm{EDOT}_{\mathrm{n}}$ is less sterically hindered, thus couplings on EDOTn amino acids are faster. 


\begin{tabular}{|c|c|c|c|}
\hline Name and Structure & Removal conditions & $\begin{array}{l}\text { Stability to the } \\
\text { removal of }\end{array}$ & Ref. \\
\hline $\begin{array}{c}\text { Pseudoprolines (oxazolidines) } \\
\text { Pseudoprolines } \\
\mathrm{R}=\mathrm{H}(\mathrm{Ser}) \text { or } \mathrm{Me}(\mathrm{Thr})\end{array}$ & $\begin{array}{l}95 \% \text { TFA and } \\
\text { scavengers }\end{array}$ & Fmoc, Alloc & $\begin{array}{l}257, \\
261, \\
263\end{array}$ \\
\hline 2-Hydroxy-4-methoxybenzyl (Hmb) & $\begin{array}{l}95 \% \text { TFA and } \\
\text { scavengers }\end{array}$ & Fmoc, Alloc & $\begin{array}{l}258, \\
264, \\
265\end{array}$ \\
\hline 2,4-Dimethoxybenzyl (Dmb) & $\begin{array}{l}95 \% \text { TFA and } \\
\text { scavengers }\end{array}$ & Fmoc, Alloc & $\begin{array}{l}255, \\
266, \\
267\end{array}$ \\
\hline 2,4,6-Trimethoxybenzyl (Tmob) & $\begin{array}{l}95 \% \text { TFA and } \\
\text { scavengers }\end{array}$ & Fmoc, Alloc & $\begin{array}{l}258, \\
268, \\
269\end{array}$ \\
\hline 1-Methyl-3-indolylmethyl (MIM) & $\begin{array}{l}\text { TFA-DCM- } \mathrm{H}_{2} \mathrm{O} \\
(95: 2.5: 2.5)\end{array}$ & Fmoc, Alloc & 259 \\
\hline 3,4-Ethylenedioxy-2-thenyl $\left(\mathrm{EDOT}_{\boldsymbol{n}}\right)$ & $\begin{array}{l}\text { TFA-DCM- }{ }_{2} \mathrm{O} \\
(95: 2.5: 2.5)\end{array}$ & Fmoc, Alloc & 259 \\
\hline
\end{tabular}

\subsubsection{Other protecting groups}

- 4-Methoxy-2-nitrobenzyl. ${ }^{270} \mathrm{It}$ is removed by photolysis at $\lambda=360 \mathrm{~nm}$ for more than $2 \mathrm{~h}$ using Cys (200 mmol per $1 \mathrm{mmol}$ of 4-methoxy-2-nitrobenzyl) as scavenger. This is a 
backbone protector, fully compatible with Boc chemistry, thereby allowing the obtention of backbone-protected peptides after HF cleavage.

- (6-Hydroxy-3-oxido-1,3-benz[d]oxathiol-5-yl)methyl ${ }^{271,272}$ and 2-hydroxy-4-methoxy5-(methylsulfinyl)benzyl. ${ }^{273}$ These are safety-catch backbone protectors which become unstable to TFA after reduction of the sulfoxide to sulfide. (6-Hydroxy-3-oxido-1,3benzoxathiol-5-yl)methyl is removed with 20 eq. each of $\mathrm{NH}_{4} \mathrm{I}$ and $\left(\mathrm{CH}_{3}\right)_{2} \mathrm{~S}$ in TFA at $0^{\circ} \mathrm{C}$ over $2 \mathrm{~h}$, whereas 2-hydroxybenzyl-4-methoxy-5-(methylsulfinyl) is removed with $\mathrm{SiCl}_{4}$-TFA-anisole-ethanedithiol, (5:90:2.5:2.5), for $2 \mathrm{~h}$ at room temperature. Acylation as well as acyl migration is faster in the case of the latter.

- Boc-N-methyl-N-[2-(methylamino)ethyl]carbamoyl-Hmb (Boc-Nmec-Hmb). ${ }^{274}$ It is a recently developed protecting group. It has been used for solid phase synthesis. After the removal of the Boc group with TFA during the cleavage of the peptide from the resin, the Nmec moiety is removed via an intramolecular cyclization in basic conditions ( $N$-methylmorpholine (10 eq) in DMF/H2O (3:7), $4-8 \mathrm{~h}$ ), leading to the Hmb protected peptide. Then, Hmb is removed with $95 \%$ TFA and scavengers. The main advantage of the Boc-Nmec-Hmb group is that after Boc removal, a cationic peptide is obtained which increase the solubility of insoluble peptides making their purification easier.

\begin{tabular}{|c|c|c|c|}
\hline Name and Structure & Removal conditions & $\begin{array}{c}\text { Stability to the } \\
\text { removal of }\end{array}$ & Ref. \\
\hline 4-Methoxy-2-nitrobenzyl & $\begin{array}{l}\text { Photolysis }(\lambda=360 \mathrm{~nm}) \\
\text { and Cys as scavenger }\end{array}$ & $\begin{array}{l}\text { Boc, } Z,{ }^{a} \text { Trt, } \\
\text { Alloc }\end{array}$ & 270 \\
\hline $\begin{array}{c}\text { (6-Hydroxy-3-oxido-1,3- } \\
\text { benz[d]oxathiol-5-yl)methyl }\end{array}$ & $\begin{array}{l}\mathrm{NH}_{4} \mathrm{I} \text { (20 eq.) and } \\
\left(\mathrm{CH}_{3}\right)_{2} \mathrm{~S} \text { (20 eq.)-TFA, } \\
2 \mathrm{~h}, 0^{\circ} \mathrm{C} \text {. }\end{array}$ & Boc, Fmoc,Trt & $\begin{array}{l}271, \\
272\end{array}$ \\
\hline $\begin{array}{l}\text { 2-Hydroxy-4-methoxy-5- } \\
\text { (methylsulfinyl) benzyl }\end{array}$ & $\begin{array}{l}\mathrm{SiCl}_{4} \text {-TFA-anisole- } \\
\text { ethanedithiol, } \\
(5: 90: 2.5: 2.5), 2 \mathrm{~h}, \mathrm{rt}\end{array}$ & Boc, Fmoc,Trt & 273 \\
\hline
\end{tabular}




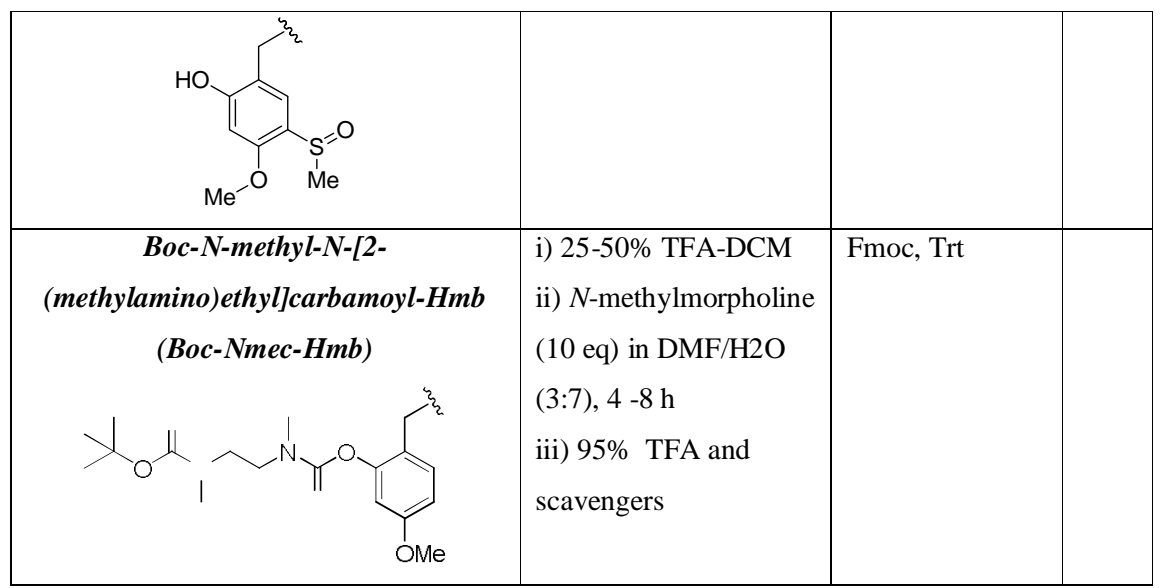

${ }^{\mathrm{a}}$ Except catalytical hydrogenation removal. 


\section{ASPARAGINE (Asn) AND GLUTAMINE (GIn)}

\subsection{General}

Asn and Gln (Figure 13) are often used without side chain protection.<smiles>NC(=O)CC(N)C(N)=O</smiles>

Asn

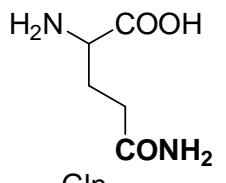

Gln

Figure 13. Asparagine (Asn) and Glutamine (Gln)

Nevertheless, unprotected derivatives show poor solubility and therefore slow coupling rates. In addition, their free primary amides can undergo two main side reactions.

1) Dehydratation during the coupling (Figure 14), which is a base-catalyzed side reaction and therefore more favoured in those coupling protocols that involve the use of base. It can be minimized using the corresponding $N^{\alpha}$-protected pentafluorophenyl esters or carbodiimide-mediated couplings in the presence of $\mathrm{HOBt}^{275,276}$ Dehydratation is more important in the Fmoc/ ${ }^{t} \mathrm{Bu}$ strategy than in the Boc/Bn one because in the latter, the use of HF apparently reverts the reaction, whereas in the former TFA is not acidic enough to revert to the amide. ${ }^{276}$

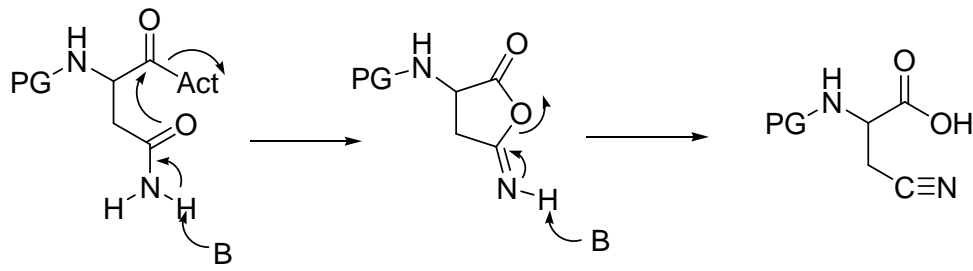

Figure 14. Dehydratation of Asn. Adapted from 277.

2) Pyroglutamyl (Figure 15) formation is a weak acid-catalyzed side reaction that occurs on $N$-terminal Gln that leads to truncated peptidic chains. Being an acid-catalyzed reaction, it has more importance in the Boc/Bn strategy and can be minimized by reducing exposure to weak acids. ${ }^{278}$

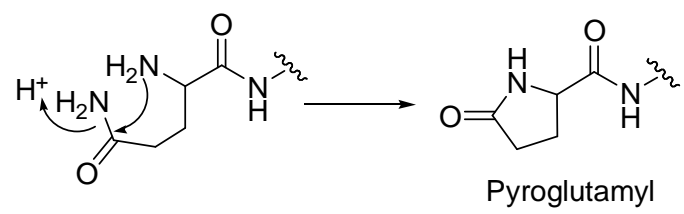

Figure 15. Pyroglutamyl formation. 
Adequate protection of Asn and Gln side chains prevents both side reactions. As for dehydratation, it is not necessary for the protecting group of choice to be stable during the whole peptide synthesis, but only during the coupling step. Furthermore, protection of Asn and Gln side chains also increases coupling yields by confering more solubility to the corresponding Asn and Gln derivatives and probably reducing the formation of hydrogen bonds that stabilize secondary structures.

Removal of the protecting groups is usually easier in Gln than in Asn, being particularly difficult in $N$-terminal Asn because of the proximity of the free and therefore protonated $\alpha$-amino group. ${ }^{281,279,280}$

Currently, the most used protecting groups are Xan (9-xanthenyl) and Trt, which are compatible with both $\mathrm{Boc} / \mathrm{Bn}$ and $\mathrm{Fmoc} / \mathrm{B}$ u strategies. In the case of the former, the Xan group protects Asn and Gln side chains only during the coupling and is removed during TFA treatments for Boc removal.

\subsection{Introduction of the protecting groups}

Protection is usually performed via acid-catalyzed reaction of the corresponding alcohol with Z-Gln or Z-Asn, followed by catalytic hydrogenolysis to eliminate the Z group and Fmoc or Boc $N^{\alpha}$ protection. ${ }^{281,282}$ In the case of 9-xanthenyl, the direct protection of the Fmoc-Asn and Fmoc-Gln has also been described. ${ }^{283}$

\subsection{Removal}

7.3.1. Protecting groups removed by acid- 9-Xanthenyl (Xan). ${ }^{282}$ It is removed by 90\% TFA and scavengers. In contrast to Trt, no extra reaction time is required when the $\alpha$-amino of Asn is free. ${ }^{279} \mathrm{Xan}$ is used in both the Boc/Bn and Fmoc/t Bu strategies. ${ }^{282,283}$ In the case of the Boc strategy, Xan is eliminated during TFA treatments to remove the Boc group; however, Asn or Gln residues can undergo dehydratation only during the coupling and thus, Xan elimination after it is a minor problem. ${ }^{283}$

- Trityl (Trt). ${ }^{280,281}$ It is removed with TFA- $\mathrm{H}_{2} \mathrm{O}-\mathrm{EDT}$ (90:5:5), and used in both the $\mathrm{Boc} / \mathrm{Bn}$ and $\mathrm{Fmoc} /{ }^{t} \mathrm{Bu}$ strategies. The time required for removal increases from $10 \mathrm{~min}$ to more than $4 \mathrm{~h}$ when the $\alpha$-amino of Asn is free. Scavengers must be used to prevent Trp alkylation. It is stable to bases and catalytic hydrogenolysis.

- 4-Methyltrityl $(M t t) \cdot{ }^{284,280}$ It is a more acid-labile alternative to the Trt group (95\% TFA, $20 \mathrm{~min}$ ), and is particularly useful when the $\alpha$-amino of Asn is free.

- Dimethylcyclopropylmethyl (Dmcp) or Cyclopropyldimethylcarbinyl (Cpd). ${ }^{285,286}$ It is removed with TFA-thioanisole-EDT-anisole (90:5:3:2), being another more acid labile 
alternative to Trt, especially when the $\alpha$-amino of Asn is free. It is more soluble and coupling rates are better than with the Trt group.

- 4,4'-Dimethoxybenzhydryl (Mbh). ${ }^{287,288}$ It is used mainly in the Boc/Bn strategy but also in the Fmoc/t $\mathrm{Bu}$ one. Its removal using TFA is slow and requires scavengers to prevent alkylation of Trp. ${ }^{275}$

- 2,4,6-Trimethoxybenzyl (Tmob). ${ }^{289}$ It is removed with 95\% TFA and scavengers. It is more acid-labile, more soluble and gives less side reactions during coupling than Mbhprotected derivatives. However, it is not currently widely used because it can cause alkylation of Trp and is reported to give worse results than the Trt group. ${ }^{290,281}$ 


\begin{tabular}{|c|c|c|c|}
\hline Name and Structure & Removal conditions & $\begin{array}{l}\text { Stability to the } \\
\text { removal of }\end{array}$ & Ref. \\
\hline 9-Xanthenyl (Xan) & 90\% TFA-scavengers & $\begin{array}{l}\text { Fmoc, Trt, } \\
\text { Alloc }\end{array}$ & $\begin{array}{l}279, \\
282, \\
283\end{array}$ \\
\hline Trityl (Trt) & $\begin{array}{l}\text { TFA- }{ }_{2} \mathrm{O}-\mathrm{EDT} \\
(90: 5: 5)\end{array}$ & $\begin{array}{l}\text { Fmoc, Trt, } \\
\text { Alloc }\end{array}$ & $\begin{array}{l}280, \\
281\end{array}$ \\
\hline 4-Methyltrityl (Mtt) & $95 \%$ TFA & $\begin{array}{l}\text { Fmoc, Trt, } \\
\text { Alloc }\end{array}$ & $\begin{array}{l}280, \\
284\end{array}$ \\
\hline $\begin{array}{c}\text { Dimethylcyclopropylmethyl (Dmcp) or } \\
\text { Cyclopropyldimethylcarbinyl (Cpd) }\end{array}$ & $\begin{array}{l}\text { TFA-thioanisole-EDT- } \\
\text { anisole }(90: 5: 3: 2)\end{array}$ & Fmoc, Alloc & $\begin{array}{l}285, \\
286\end{array}$ \\
\hline $\begin{array}{c}\text { 4,4'-Dimethoxybenzhydryl (Mbh) } \\
\sim \sim\end{array}$ & $\begin{array}{l}1 \mathrm{M} \text { TMSBr- } \\
\text { thioanisole-EDT- } m \text { - } \\
\text { cresol in TFA }(2 \mathrm{~h} \text { at } \\
\left.0^{\circ} \mathrm{C}\right)\end{array}$ & Fmoc, Alloc & $\begin{array}{l}275, \\
287, \\
288\end{array}$ \\
\hline 2,4,6-Trimethoxybenzyl (Tmob) & $\begin{array}{l}95 \% \text { TFA-DCM and } \\
\text { scavengers }\end{array}$ & Fmoc, Alloc & $\begin{array}{l}281, \\
289, \\
290\end{array}$ \\
\hline
\end{tabular}




\section{ARGININE (Arg)}

\subsection{General}

Protection of the guanidino group of $\operatorname{Arg}$ (Figure 16) is required to prevent deguanidination, which renders Orn (Figure 17) ${ }^{291}$ and $\delta$-lactam formation (Figure 18) 277 as a result of the nucleophilicity of the guanidino group. Arg side chain protection remains unsolved in peptide synthesis because of the difficulty to remove the protecting groups.

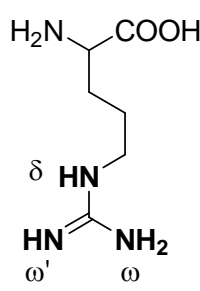

Figure 16. Arginine (Arg)

Since the guanidino group is basic $(\mathrm{pKa}=12.5)$, it remains protonated in most of the conditions used for peptide synthesis. ${ }^{292,293}$ To prevent deprotonation in Fmoc/tBu SPS, washings with $0.25 \mathrm{M} \mathrm{HOBt}$ are carried out between Fmoc removal and the next coupling. ${ }^{294}$ However, if deprotonation takes place, deguanidination occurs after acylation of the neutral guanidino group. This drawback stimulated research into protecting groups for Arg.

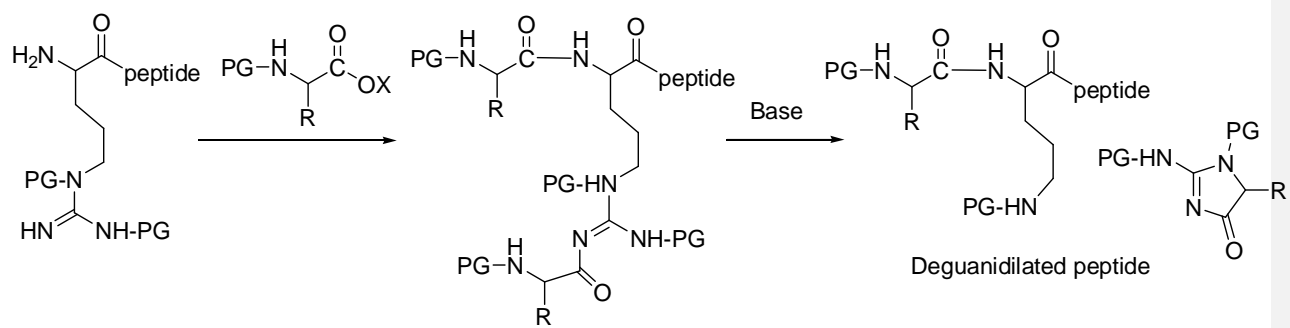

Figure 17. Acylation of the side chain of Arg during amino acid coupling, followed by base-catalyzed deguanidination. Adapted from ${ }^{291}$

Arg derivatives tend to be worse acylating reagents compared with other amino acid derivatives, mainly because of the formation of the $\delta$-lactam from the activated species (Figure 18). In a solid-phase mode, the presence of the $\delta$-lactam does not translate in an impurity in the crude reaction, because it is not reactive but it is translated in a less active species to be coupled. 


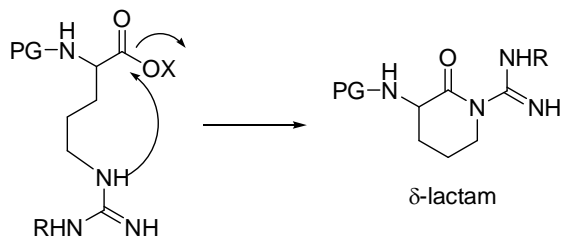

Figure 18. Mechanism of $\delta$-lactam formation. $\mathrm{R}=\mathrm{H}$ or protecting group. Adapted from 277.

In principle, protection of all the nitrogens of the guanidino group is required to fully mask its nucleophilicity. However, diprotection and monoprotection are easier to achieve and minimize side reactions when bulky and electron-withdrawing protecting groups are used.

The most used protecting strategy is sulfonyl protection of the $\omega$-amino function. For the Boc/Bn strategy, the most used group is Tos while for the Fmoc/ ${ }^{t} \mathrm{Bu}$ strategy the most popular protecting groups are $\mathrm{Pbf}$ (pentamethyl-2,3-dihydrobenzofuran-5sulfonyl) and Pmc (2,2,5,7,8-pentamethylchroman-6-sulfonyl). However, both, but particularly Pmc, are too acid stable and their removal in peptides with multiple Args is especially problematic.

\subsection{Introduction of the protecting groups}

It depends on the nature of the protecting group, in the case of sulfonyl-protecting groups, which are the most used ones, they are usually introduced by reaction of the corresponding sulfonyl chloride with $\mathrm{Z}$-Arg- $\mathrm{OH}$ in $\mathrm{H}_{2} \mathrm{O}$-acetone using $\mathrm{NaOH}$ as a base. To obtain the corresponding Fmoc/Boc derivative, the $\mathrm{Z}$ group is removed by catalytic hydrogenolysis and the Fmoc/Boc group is incorporated under regular conditions. ${ }^{295}$

\subsection{Removal}

\subsubsection{Protecting groups removed by acid.}

Arylsulfonyl $\omega$-protection: Although this kind of protection does not fully prevent $\delta$ lactam formation, this process can be minimized by using carbodiimides in the presence of HOBt derivatives to decrease the activity of the active $O$-acylisourea. ${ }^{184}$

- Tosyl (Tos). It is removed with HF, TFMSA-TFA-thioanisole or $\mathrm{Na} / \mathrm{NH}_{3}{ }^{296}$ It is the most used protecting group in the Boc/Bn solid phase strategy. ${ }^{297}$

- 2,2,5,7,8-Pentamethylchroman-6-sulfonyl $(\mathrm{Pmc}){ }^{295} \mathrm{It}$ is widely used in the Fmoc/t $\mathrm{Bu}$ solid phase strategy. It is removed by TFA-scavengers. Currently, it is being replaced by the Pbf group. 
- 2,2,4,6,7-Pentamethyl-2,3-dihydrobenzofuran-5-sulfonyl (Pbf). ${ }^{298}$ It is removed by TFA-scavengers and is more acid-labile than the Pmc group. Currently, it is the best Arg-protecting group for the Fmoc/t Bu solid phase strategy, although it is still too acidstable in peptides with multiple Arg-containing peptides where long reaction times are required.

- Mesitylyl-2-sulfonyl (Mts). ${ }^{299,300}$ It is removed with TFMSA-TFA-thioanisole. It is used in the Boc/Bn solid phase strategy and is more acid-labile than the tosyl group.

- 4-Methoxy-2,3,6-trimethylphenylsulfonyl (Mtr). ${ }^{301}$ It is removed by TFA-thioanisole.

Although it is still used, it has been mostly replaced by the more acid-labile Pmc or Pbf in Fmoc/t'Bu chemistry.

- 1,2-Dimethylindole-3-sulfonyl (MIS). ${ }^{302}$ It is a recently developed protecting group, which is much more TFA-labile than Pbf. It is completely removed with 50\% TFA in 30 min, even in multiple Arg-containing peptides.

\section{Other kinds of Arg protection}

- $\omega, \omega$ '-bis-tert-Butyloxycarbonyl (bis-Boc).$^{303}$ It is removed with $90-95 \%$ TFA in the presence of scavengers, prevents deguanidination but does not completely prevent $\delta$ lactam formation. ${ }^{304,305}$ The coupling rates of bis-Boc-protected Arg are low.

- $\omega-5$-Dibenzosuberenyl (Suben), 5-Dibenzosuberyl (Sub) and 2-Methoxy-5dibenzosuberyl (MeSub). ${ }^{306}$ They are the most acid-labile derivatives (removed with 25$50 \%$ TFA) and are reported to minimize $\delta$-lactam formation and deguanidination because of their steric hindrance. Although they look very promising, they have not been widely used.

- $\omega$-Nitro $\left(\mathrm{NO}_{2}\right){ }^{307}$ It prevents $\delta$-lactam formation and deguanidination in most cases. It can be removed with HF (SPS) or catalytic hydrogenolysis. In both cases long reaction times are required, which is an inconvenience in the case of sensitive peptides. For instance, in the case of hydrogenolysis, partial hydrogenation of Trp or even Phe can occur. ${ }^{308}$ Due to the clean removal of the nitro group by hydrogenolysis and its low cost, nitro protection is still used for large-scale solution synthesis of peptides ${ }^{309,310}$ and even for SPS, where the nitro group is removed by hydrogenolysis after the cleavage from the resin. ${ }^{311}$ 


\begin{tabular}{|c|c|c|c|}
\hline Name and Structure & Removal conditions & $\begin{array}{l}\text { Stability to the } \\
\text { removal of }\end{array}$ & Ref. \\
\hline Protonation & - & - & 294 \\
\hline p-Toluenesulfonyl (Tos) & $\begin{array}{l}\text { 1) } \mathrm{HF} \\
\text { 2) TFMSA-TFA- } \\
\text { thioanisole } \\
\text { 3) } \mathrm{Na} / \mathrm{NH}_{3}\end{array}$ & $\begin{array}{l}\text { Boc, Fmoc, Trt, } \\
\text { Alloc }\end{array}$ & $\begin{array}{l}296, \\
297\end{array}$ \\
\hline $\begin{array}{l}\text { 2,2,5,7,8-Pentamethylchroman-6- } \\
\text { sulfonyl (Pmc) }\end{array}$ & $\begin{array}{l}90 \% \text { TFA-scavengers } \\
\left(\mathrm{H}_{2} \mathrm{O} \text { and TIS) several }\right. \\
\text { hours. }\end{array}$ & $\begin{array}{l}\text { Fmoc, Trt, } \\
\text { Alloc }\end{array}$ & 295 \\
\hline $\begin{array}{l}\text { 2,2,4,6,7-Pentamethyl-2,3- } \\
\text { dihydrobenzofuran-5-sulfonyl (Pbf) }\end{array}$ & $\begin{array}{l}90 \text { TFA-scavengers } \\
\left(\mathrm{H}_{2} \mathrm{O} \text { and TIS }\right) 1 \mathrm{~h} \\
\text { (longer times in } \\
\text { multiple arginine } \\
\text { containing peptides) }\end{array}$ & $\begin{array}{l}\text { Fmoc, Trt, } \\
\text { Alloc }\end{array}$ & 298 \\
\hline Mesitylyl-2-sulfonyl (Mts) & $\begin{array}{l}\text { TFMSA-TFA- } \\
\text { thioanisole }\end{array}$ & $\begin{array}{l}\text { Boc, Fmoc, Trt, } \\
\text { Alloc }\end{array}$ & $\begin{array}{l}299, \\
300\end{array}$ \\
\hline $\begin{array}{c}\text { 4-Methoxy-2,3,6- } \\
\text { trimethylphenylsulfonyl (Mtr) }\end{array}$ & 95\% TFA-thioanisole & $\begin{array}{l}\text { Fmoc, Trt, } \\
\text { Alloc }\end{array}$ & 301 \\
\hline $\begin{array}{c}\text { 1,2-Dimethylindole-3-sulfonyl (MIS) } \\
\qquad c^{2 / 2}\end{array}$ & $\begin{array}{l}50 \% \text { TFA and } \\
\text { scavengers, } 30 \mathrm{~min}\end{array}$ & Fmoc, Alloc & 302 \\
\hline
\end{tabular}




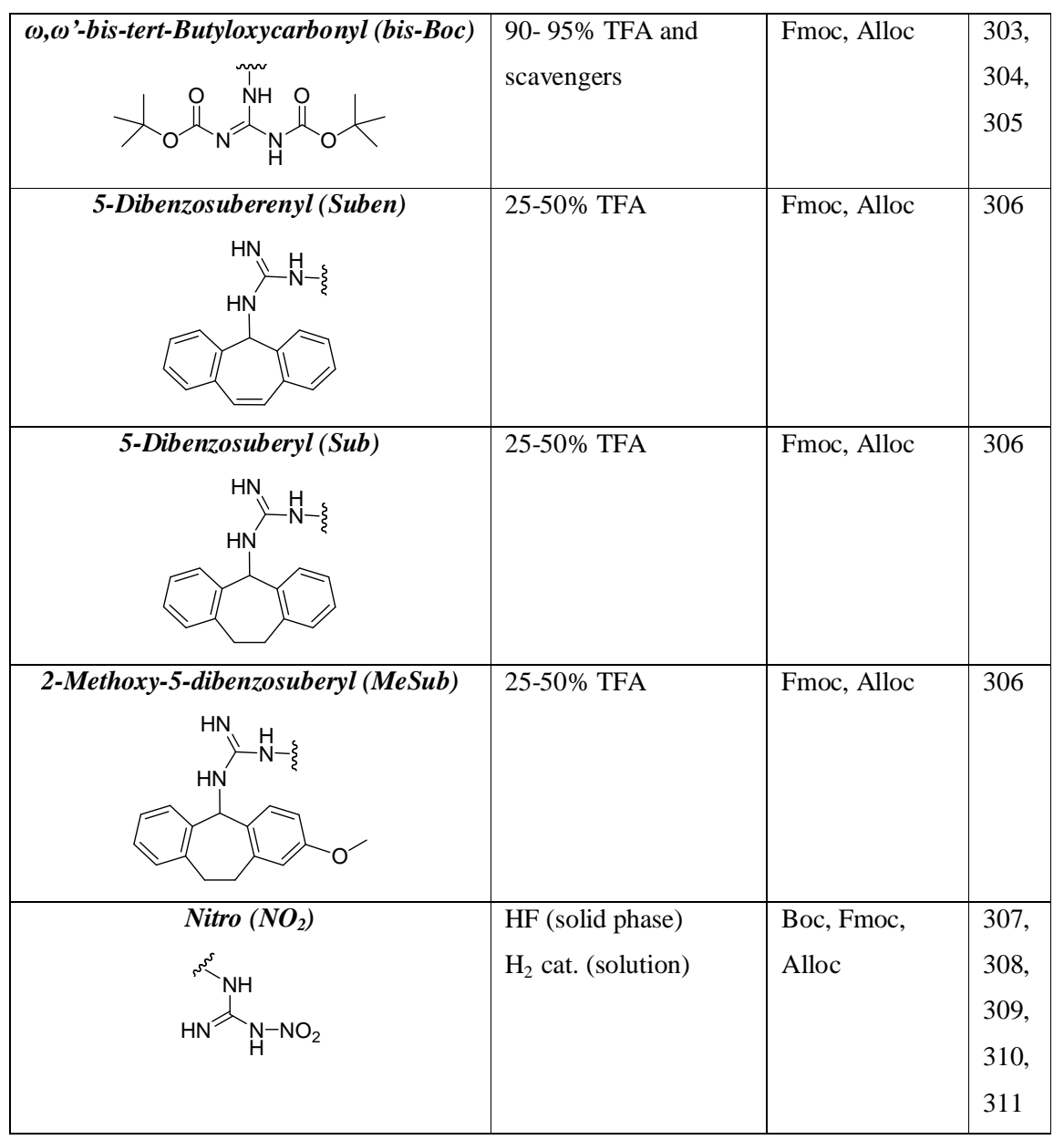

\subsubsection{Protecting groups removed by base}

- Trifluoroacetyl ( $\mathrm{ffa}$ ). It has been applied recently for the protection of guanidines used in solution Boc peptide synthesis and Fmoc/ ${ }^{t}$ Bu SPPS. However, although there are references of tfa-protected Arg derivatives, ${ }^{312,313,314}$ to date it has not been implemented for Arg protection in peptide synthesis. 


\begin{tabular}{|c|c|c|c|}
\hline Name and Structure & Removal conditions & $\begin{array}{c}\text { Stability to the } \\
\text { removal of }\end{array}$ & Ref. \\
\hline Trifluoroacetyl (tfa) & $\begin{array}{l}\text { 1) } \mathrm{K}_{2} \mathrm{CO}_{3}-\mathrm{MeOH}-\mathrm{H}_{2} \mathrm{O} \\
\text { (solution) } \\
\text { 2) } \mathrm{K}_{2} \mathrm{CO}_{3}-\mathrm{MeOH}-\mathrm{DMF}- \\
\mathrm{H}_{2} \mathrm{O} \text { (solid phase) }\end{array}$ & $\begin{array}{l}\text { Boc, Fmoc, Z, } \\
\text { Trt, Alloc }\end{array}$ & $\begin{array}{l}312, \\
313, \\
314\end{array}$ \\
\hline
\end{tabular}

${ }^{\mathrm{a}}$ Catalytical hydrogenation removal.

\subsubsection{Other protecting groups}

- Nitro $\left(\mathrm{NO}_{2}\right)$. See protecting groups removed by acid.

- $\omega, \omega$ '-Bis-benzyloxycarbonyl (bis-Z). ${ }^{315}$ Its removal by catalytic hydrogenation requires long reaction times. It is used mostly in Boc/Bn chemistry but also in the $\mathrm{Fmoc} /{ }^{t} \mathrm{Bu}$ strategy.

- $\omega, \omega$ 'bis-allyloxycarbonyl (Alloc). ${ }^{164}$ It is removed with $\mathrm{Pd}\left(\mathrm{PPh}_{3}\right)_{4}$ and scavangers (dimethylbarbituric acid) $^{316}$ and is compatible with the Boc/Bn solid phase strategy. The base treatment required to remove the Fmoc group also eliminates one of the Alloc groups.

\begin{tabular}{|c|c|c|c|}
\hline Name and Structure & Removal conditions & $\begin{array}{l}\text { Stability to the } \\
\text { removal of }\end{array}$ & Ref. \\
\hline $\begin{array}{c}\omega, \omega^{\prime} \text {-bis-benzyloxycarbonyl }(\boldsymbol{Z}) \\
\mathrm{NH} \\
\mathrm{NH}\end{array}$ & $\mathrm{H}_{2}$ cat. (long time) & Boc, Fmoc, Trt & 315 \\
\hline$\omega, \omega^{\prime}$-bis- allyloxycarbonyl (Alloc) & $\begin{array}{l}\mathrm{Pd}\left(\mathrm{PPh}_{3}\right)_{4} \text {, barbituric } \\
\text { acid }\end{array}$ & $\begin{array}{l}\text { Boc, Fmoc, Z, }{ }^{a} \\
\text { Trt }\end{array}$ & $\begin{array}{l}164, \\
316\end{array}$ \\
\hline
\end{tabular}

${ }^{\mathrm{a}}$ Except catalytical hydrogenation removal. 


\section{CYSTEINE (Cys)}

\subsection{General}

Protection of the side chain of Cys (Figure 19) is mandatory in peptide synthesis because the nucleophilic thiol can otherwise be acylated, alkylated or oxidized to disulfide by air.

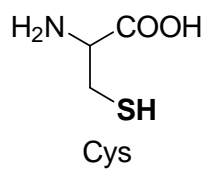

Figure 19. Cysteine (Cys)

Nevertheless, even protected Cys can undergo several side reactions. The most relevant are listed here.

- Oxidation and alkylation of the thioether. Although less critical than in the case of Met, it can also occur. ${ }^{317,318,319}$ Oxidation of the Cys residues during global deprotection can be minimized using $10 \%$ of $\mathrm{H}_{2} \mathrm{O}$ as scavenger. ${ }^{121}$

- $\beta$-Elimination (Figure 20) occurs when protected Cys is exposed to strong bases, such as sodium in liquid ammonia (required to remove the Benzyl group), alkaline conditions or hydrazylnolysis, but also to strong acids such as HF. This side reaction is particularly critical in the case of $C$-terminal Cys, which in the Fmoc/t $\mathrm{Bu}$ strategy undergoes $\beta$ elimination followed by piperidine addition to give piperidylalanine residue. The extent of $\beta$-elimination also depends strongly on the protecting group used, $S^{t} \mathrm{Bu}$ being the worst case followed by Acm and $\mathrm{Trt}^{320,321}$ The Bn group can also produce $\beta$ elimination.

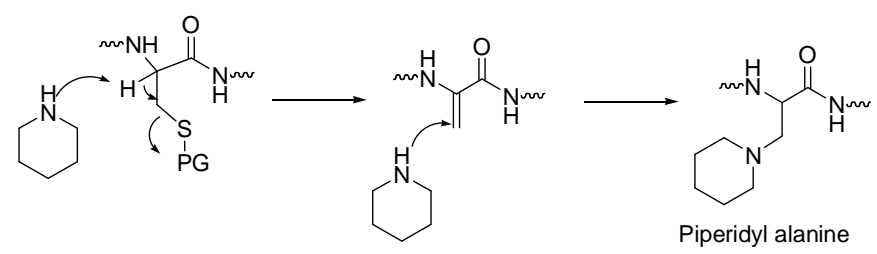

Figure 20. Base-catalyzed $\beta$-elimination of protected Cys followed by piperidine addition leading to piperidyl alanine.

- Reaction with carbocations resulting from the elimination of protecting groups: after its deprotection, Cys can react with the cations generated in acidic conditions. For instance, S-tert-butylated Cys has been observed after the removal of the Boc group or after global deprotection in a Fmoc ${ }^{t} \mathrm{Bu}$ strategy. ${ }^{322}$ 
- Reattachment to the resin: resin bound carbocations generated in the acidolytic cleavage from resins can react with both protected and unprotected Cys, thus causing reattachment of the peptide to the resin. ${ }^{323}$

- Transfer of Acm (Acetamidomethyl) group to Ser, Thr, Gln and Tyr during Acm removal. 324325326

- Formation of thiazolidines of $N$-terminal Cys (Figure 21) can take place if Hisprotecting groups such as Bom (benzyloxymethyl) or Bum (tert-butyloxymethyl), which generate formaldehyde when removed, are present. It can be minimized using Cys as scavenger. ${ }^{327,328}$
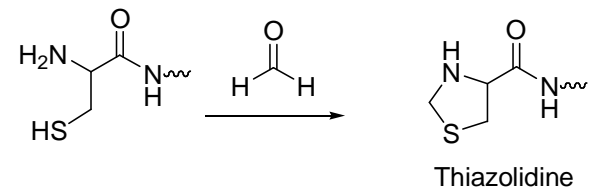

Figure 21. Thiazolidine formation by reaction of $N$-terminal Cys with formaldehyde.

- Racemization: Cys is highly prone to racemize during the anchoring to the solid support or during the couplings. ${ }^{329} 330$ The extent of the racemization also depends on the $S$-protecting groups $\left(\mathrm{S}^{t} \mathrm{Bu}>\mathrm{Trt}>\mathrm{Acm}>\mathrm{MeBn}>{ }^{t} \mathrm{Bu}\right)^{331,332,333,334,335}$ and coupling methods used (favoured if pre-activation in the presence of base is performed and in the coupling methods involving the use of base). Epimerization of the Cys linked to a hydroxyl resin can even take place during the synthesis as a result of the repetitive base treatments to remove the Fmoc group, 2-chlorotrityl resin being the least prone to this process. $^{331,336}$

The most used protecting groups for the Fmoc/tBu strategy are the Acm or Trt groups, when the desired product is the disulfide, and the Trt group when the desired product is the free thiol. For the Boc/Bn strategy, Bn, and Meb (p-methylbenzyl) are the most used to obtain the free thiol and Acm to obtain disulfides.

\subsection{Introduction of the protecting groups}

The Cys thiol shows high nucleophilicity, therefore Cys thiol protection is usually carried out using fully unprotected Cys as starting material. The $S$-protecting agents used can be alkyl halides or tosylates, under acidic or basic conditions, or alcohols, which are dehydrated under acidic conditions. Benzyl-type protection can also be performed via reduction of the thiazolidine formed with the corresponding benzaldehyde. ${ }^{337}$ 


\subsection{Removal}

The classification of the protecting group of Cys is particularly complex because most of the protecting groups used can be removed either by oxidation to the disulfide bridge or by other mechanisms. The following classification has drawn up taking into account these other mechanisms but also indicating the conditions for the oxidative removal in each particular case.

\subsubsection{Protecting groups removed by acid.}

- p-Methylbenzyl (Meb). ${ }^{338}$ More acid-labile than the Bn, it is removed with HF and scavengers at low temperatures. ${ }^{339} 340$ It is gradually replacing the $\mathrm{Bn}$ in the $\mathrm{Boc} / \mathrm{Bn}$ solid phase strategy. It can also be removed with $\mathrm{Tl}(\mathrm{III})$ trifluoroacetate or with $\mathrm{MeSiCl}_{3}$ in the presence of diphenylsulfoxide to yield disulfide bridges. However, $p$ methoxybenzyl (Mob) is usually a cleaner option. ${ }^{341}$

- p-Methoxybenzyl (Mob). ${ }^{338}$ It is more acid-labile than Meb and is also used in the Boc/Bn solid phase strategy. However, it is partially removed in the repetitive treatments to remove the Boc group when long peptide sequences are synthesized. ${ }^{338}$ It is completely removed by $\mathrm{HF}$ at $0^{\circ} \mathrm{C}$ and scavengers, TFMSA/TFA ${ }^{342}$ and $\mathrm{Hg}$ (II) acetate or trifluoroacetate in TFA or $\mathrm{AcOH}$ respectively. ${ }^{343}$ It can be selectively removed in the presence of Meb using $\mathrm{Ag}(\mathrm{I})$ trifluoromethanesulfonate in TFA. ${ }^{344} \mathrm{An}$ intramolecular disulfide bridge between two $\mathrm{Cys}(\mathrm{Mob})$-protected residues can be formed by removing the Mob group with $\mathrm{MeSiCl}_{3}$ or $\mathrm{SiCl}_{4}$ in TFA in the presence of diphenyl sulfoxide at $4^{\circ} \mathrm{C}$ in $30 \mathrm{~min}^{345}$ In addition, oxidative removal with $\mathrm{Tl}(\mathrm{III})$ trifluoroacetate also leads to the formation of a disulfide bridge by reaction with a free Cys side chain.

- Trityl (Trt). ${ }^{346}$ It is removed with TFA and scavengers, such as triisopropylsilane (TIS) to prevent retritylation, or $\mathrm{AgNO}_{3} \cdot{ }^{347}$ It is used for the $\mathrm{Fmoc} / \mathrm{Bu}$ strategy although Fmoc-Cys(Trt) can undergo racemization in basic carboxyl activation conditions. ${ }^{332}$ It can also be removed by oxidation with iodine, thereby leading to a dilulfide bridge by reaction with a free Cys side chain. Other oxidative removals are listed in the table. ${ }^{348}$

- Monomethoxytrityl (Mmt). ${ }^{349}$ It is removed with diluted TFA and scavengers. It is considerably more acid-labile than the $S$-trityl group and can be removed selectively in its presence as well as in the presence of ${ }^{t} \mathrm{Bu}$-protecting groups. Oxidative removal is similar to the case of the Trt group.

- Trimethoxybenzyl (Tmob). ${ }^{350}$ It is another more acid-labile alternative to the Trt group for the Fmoc/ $/ \mathrm{Bu}$ strategy. It is removed with diluted TFA (5-30\%) and scavengers; 
however, the trimethoxybenzyl cation resulting from its cleavage can alkylate Trp residues.

- 9-Xanthenyl (Xan). ${ }^{332}$ It has similar stability features to Mmt, thus, it can also be removed selectively in the presence of $S$-trityl and ${ }^{t} \mathrm{Bu}$-protecting groups or Rink and PAL handles.

- 2,2,4,6,7-Pentamethyl-5-dihydrobenzofuranylmethyl (Pmbf). ${ }^{351}$ It is a relatively new highly acid-labile protecting group (Fmoc/t $\mathrm{Bu}$ chemistry). It is removed with TFA-TESDCM (0.5-5-94.5) in $2 \mathrm{~h}$ to render the free thiol. Alternatively, treatment with $\mathrm{I}_{2}$ yields the disulfide bridge. This protecting group has been succesfully applied to obtain oxytocin.

- Benzyl $(B n){ }^{352}$ It is removed with $\mathrm{HF}$ at $25^{\circ} \mathrm{C}$ or $\mathrm{Na}$ in liquid ammonia. However, although still used, it is being replaced by other benzyl derivatives that do not require such harsh conditions for their removal.

- tert-Butyl $\left({ }^{t} \mathrm{Bu}\right)$ and 1-Adamantyl $(1-A d a){ }^{353}$ Both are fully stable to TFA and can therefore be used in the Boc/Bn strategy. They are also quite stable to HF at low temperatures but cleaved at higher temperatures in the presence of scavengers. ${ }^{335}$ They are also stable to $\mathrm{Ag}$ (I) trifluoromethanesulfonate in TFA, ${ }^{344}$ which quantitatively removes the $S$-Mmt group, and also to iodine oxidation. Other possible cleavage conditions are listed in the table. ${ }^{343}$ 


\begin{tabular}{|c|c|c|c|c|}
\hline Name and Structure & $\begin{array}{l}\text { Removal conditions } \\
\quad \text { (final } S \text { form) }\end{array}$ & $\begin{array}{c}\text { Stability to } \\
\text { the removal } \\
\text { of }\end{array}$ & $\begin{array}{l}\text { Compatibility } \\
\text { with the most } \\
\text { important sulfur } \\
\text { protecting groups }\end{array}$ & Ref \\
\hline p-Methylbenzyl (Meb) & $\begin{array}{l}\text { 1) } \mathrm{HF} \text {, scavengers } \\
\text { (SH) } \\
\text { 2) } \mathrm{MeSiCl}_{3} \text { or } \mathrm{SiCl}_{4} \text {, } \\
\mathrm{TFA}, \mathrm{Ph}_{2} \mathrm{SO},(\mathbf{S}-\mathrm{S}) \\
\text { 3) } \mathrm{Tl}(\mathrm{TFA})_{3}(\mathbf{S}-\mathrm{S})\end{array}$ & $\begin{array}{l}\text { Boc, Fmoc, } \\
\text { Trt, Alloc }\end{array}$ & $\begin{array}{l}\text { Trt, }{ }^{a} \mathrm{Acm}, \mathrm{S}^{t} \mathrm{Bu}, \\
\text { Npys, } \mathrm{Fm}^{\mathrm{b}}\end{array}$ & $\begin{array}{l}338, \\
339, \\
340, \\
341\end{array}$ \\
\hline $\begin{array}{l}\text { p-Methoxybenzyl (Mob) } \\
\text { EMBED ChemDraw.Document.6.0 }\end{array}$ & $\begin{array}{l}\text { 1) } \mathrm{HF} \text {, scavengers } \\
\text { (SH) } \\
\text { 2) } \mathrm{TFMSA}-\mathrm{TFA}(\mathrm{SH}) \\
\text { 3) } \mathrm{Hg}(\mathrm{OAc})_{2} \text { in TFA } \\
\text { or } \mathrm{Hg}(\mathrm{TFA})_{2} \text {, in } \\
\mathrm{AcOH}(\mathrm{SH}) \\
\text { 4) } \mathrm{Ag}(\mathrm{TFMSO}) \\
\text { (SH) } \\
\text { 5) } \mathrm{Tl}(\mathrm{TFA})_{3}(\mathrm{~S}-\mathrm{S}) \\
\text { 6) } \mathrm{MeSiCl}{ }_{3} \text { or } \mathrm{SiCl}_{4} \\
\mathrm{TFA}, \mathrm{Ph}_{2} \mathrm{SO}, 4^{\circ} \mathrm{C}, 30 \\
\text { min, }(\mathrm{S}-\mathrm{S})\end{array}$ & $\begin{array}{l}\text { Boc, }{ }^{c} \text { Fmoc, } \\
\text { Trt, Alloc }\end{array}$ & $\begin{array}{l}\text { Trt, }{ }^{a} \mathrm{Acm}, \mathrm{S}^{t} \mathrm{Bu}, \\
\text { Npys, } \mathrm{Fm}^{\mathrm{b}}\end{array}$ & $\begin{array}{l}338, \\
342, \\
343, \\
344, \\
345\end{array}$ \\
\hline Trityl (Trt) & $\begin{array}{l}\text { 1) } 95 \% \text { TFA, } \\
\text { scavengers (SH) } \\
\text { 2) } \mathrm{Hg}(\mathrm{OAc})_{2}(\mathbf{S H}) \\
\text { 3) } \mathrm{AgNO}_{3}(\mathbf{S H}) \\
\text { 4) } \mathrm{I}_{2}(\mathrm{~S}-\mathrm{S}) \\
\text { 5) } \mathrm{Tl}(\mathrm{TFA})_{3}(\mathbf{S}-\mathbf{S})\end{array}$ & Fmoc, Alloc & $\begin{array}{l}\text { Meb/Mob, }{ }^{a} \text { Acm, }{ }^{d} \\
\text { S }^{t} \mathrm{Bu}, \text { Npys, } \mathrm{Fm}^{\mathrm{b}}\end{array}$ & $\begin{array}{l}332, \\
346 \\
347 \\
348\end{array}$ \\
\hline Monomethoxytrityl (Mmt) & $\begin{array}{l}\text { 1) } 1 \% \text { TFA, } \\
\text { scavengers }(\mathbf{S H}) \\
\text { 2) } \mathrm{Hg}(\mathrm{OAc})_{2}(\mathbf{S H}) \\
\text { 3) } \mathrm{AgNO}_{3}(\mathbf{S H}) \\
\text { 4) } \mathrm{I}_{2}(\mathbf{S}-\mathrm{S}) \\
\text { 5) } \mathrm{Tl}(\mathrm{TFA})_{3}(\mathbf{S}-\mathbf{S})\end{array}$ & Fmoc, Alloc & $\begin{array}{l}\text { Meb/Mob, }{ }^{a} \text { Acm, }{ }^{d} \\
\text { S }^{t} \mathrm{Bu}, \text { Npys, } \text { Fm }^{\mathrm{b}}\end{array}$ & 349 \\
\hline Trimethoxybenzyl (Tmob) & $\begin{array}{l}\text { 5-30\% TFA, } \\
\text { scavengers }(\mathbf{S H}) \\
\text { 2) } \mathrm{I}_{2}(\mathbf{S}-\mathbf{S}) \\
\text { 3) } \mathrm{Tl}(\mathrm{TFA})_{3}(\mathbf{S}-\mathbf{S})\end{array}$ & Fmoc, Alloc & & 350 \\
\hline
\end{tabular}




\begin{tabular}{|c|c|c|c|}
\hline 9-Xanthenyl (Xan) & $\begin{array}{l}\text { 1\% TFA, scavengers } \\
\text { (SH) }\end{array}$ & Fmoc, Alloc & 332 \\
\hline $\begin{array}{l}\text { 2,2,4,6,7-pentamethyl-5- } \\
\text { dihydrobenzofuranylmethyl (Pmbf) }\end{array}$ & $\begin{array}{l}\text { 1) TFA-TES-DCM } \\
(0.5-5-94.5) \text { in } 2 \mathrm{~h} \\
\text { (SH) } \\
\text { 2) } \mathrm{I}_{2}(\mathrm{~S}-\mathrm{S})\end{array}$ & Fmoc & 351 \\
\hline Benzyl (Bn) & $\begin{array}{l}\text { 1) } \mathrm{HF}(\mathbf{S H}) \\
\text { 2) } \mathrm{Na}, \mathrm{NH}_{3}(\mathbf{S H})\end{array}$ & $\begin{array}{l}\text { Boc, Fmoc, } \\
\text { Trt, Alloc }\end{array}$ & 352 \\
\hline $\begin{array}{c}\text { tert-Butyl }\left({ }^{t} \mathrm{Bu}\right) \\
\perp \\
\end{array}$ & $\begin{array}{l}\text { 1) } \mathrm{HF}\left(20^{\circ} \mathrm{C}\right) \\
\text { scavengers (SH) } \\
\text { 2)TFMSA-TFA and } \\
\text { scavengers (SH) } \\
\text { 3) } \mathrm{Hg}(\mathrm{OAc})_{2} \text { in TFA } \\
(\mathbf{S H})\end{array}$ & $\begin{array}{l}\text { Boc, Fmoc, } \\
\text { Trt, Alloc }\end{array}$ & $\begin{array}{l}335, \\
343, \\
344, \\
353\end{array}$ \\
\hline 1-Adamantyl (1-Ada) & $\begin{array}{l}\text { 1) } \mathrm{HF}\left(20^{\circ} \mathrm{C}\right) \\
\text { scavengers }(\mathbf{S H}) \\
\text { 2)TFMSA/TFA and } \\
\text { scavengers }(\mathbf{S H}) \\
\text { 3) } \mathrm{Hg}(\mathrm{OAc})_{2} \text { in TFA } \\
(\mathbf{S H})\end{array}$ & $\begin{array}{l}\text { Boc, Fmoc, } \\
\text { Trt, Alloc }\end{array}$ & $\begin{array}{l}335, \\
343, \\
344, \\
353\end{array}$ \\
\hline
\end{tabular}

${ }^{a}$ The Trt group should be removed first

${ }^{\mathrm{b}}$ The Fm should be removed first

${ }^{\mathrm{c}}$ Except for repetitive treatments

${ }^{\mathrm{d}}$ Trt should be removed first with TFA solutions

\subsubsection{Protecting groups removed by base}

- 9-Fluorenylmethyl $(\mathrm{Fm}){ }^{354} \mathrm{It}$ is removed with base (i.e. $50 \%$ piperidine-DMF for $2 \mathrm{~h}$ or $10 \%$ piperidine-DMF overnight) $)^{355}$ and is very stable to strong acids such as HF. It is used in the Boc/Bn solid-phase strategy. It can be removed on solid phase or in solution, thereby yielding a disulfide because of air oxidation unless reducing thiols are employed. It is resistant to oxidative cleavage with iodine or Tl(TFA) ${ }_{3}$ of other Cysprotecting groups. ${ }^{335}$

- 2-(2,4-Dinitrophenyl)ethyl (Dnpe). ${ }^{356}$ It is removed with bases such as piperidineDMF (1:1) in 30-60 min, thereby yielding the disulfide bridge, or in the presence of $\beta$ mercaptoethanol to give the free thiol. It is a less sterically hindered alternative to the 
Fm group for the Boc/Bn strategy (specially suited to facilitate the cleavage of peptides with $C$-terminal Cys), stable to strong acids such as $\mathrm{HF}$ and oxidative conditions to form disulfide bridges with $\mathrm{Acm}\left(\mathrm{I}_{2}\right.$ or $\mathrm{Tl}(\mathrm{TFA})_{3}$ in TFA).

- Benzyl (Bn). See protecting groups removed by acid.

- 9-Fluorenylmethoxycarbonyl (Fmoc). ${ }^{357}$ Only preliminary solution studies are available for Cys thiol protection with Fmoc. It seems to be more base-labile than the Fm group. It is removed with TEA in the presence of $I_{2}$ or benzenethiol in DCM to yield the corresponding disulfide. These removal conditions do not affect the $N^{\alpha}$-Fmoc group.

\begin{tabular}{|c|c|c|c|c|}
\hline Name and Structure & Removal conditions & $\begin{array}{c}\text { Stability to } \\
\text { the removal } \\
\text { of }\end{array}$ & $\begin{array}{l}\text { Compatibility with } \\
\text { other sulfur } \\
\text { protecting groups }\end{array}$ & Ref \\
\hline 9-Fluorenylmethyl (Fm) & $\begin{array}{l}\text { 1) } 10-50 \% \text { piperidine } \\
\text { in DMF (S-S) } \\
\text { 2) DBU in DMF } \\
\text { (S-S) }\end{array}$ & $\begin{array}{l}\text { Boc, Z, }{ }^{\text {a }} \text { Trt, } \\
\text { Alloc }\end{array}$ & $\begin{array}{l}\mathrm{Meb} / \mathrm{Mob} / \mathrm{Trt}, \\
\text { Acm }^{\mathrm{b}}\end{array}$ & $\begin{array}{l}335 \\
354 \\
355\end{array}$ \\
\hline 2-(2,4-Dinitrophenyl)ethyl (Dnpe) & $\begin{array}{l}\text { Piperidine:DMF (1:1) } \\
\text { (S-S) } \\
\text { in the presence of } \\
\text { mercaptoethanol: (SH) }\end{array}$ & $\begin{array}{l}\text { Boc, Z, }{ }^{\text {a }} \text { Trt, } \\
\text { Alloc }\end{array}$ & & 356 \\
\hline 9-Fluororenylmethoxycarbonyl (Fmoc) & $\begin{array}{l}\text { TEA-benzenethiol or } \\
\mathrm{I}_{2}(\mathbf{S}-\mathbf{S})\end{array}$ & $\begin{array}{l}\text { Boc, } Z{ }^{\text {a }} \\
\text { Trt, Alloc }\end{array}$ & & 357 \\
\hline
\end{tabular}

\footnotetext{
${ }^{a}$ Except catalytical hydrogenolysis.

${ }^{\mathrm{b}}$ The Fm should be removed first
}

\subsubsection{Other protecting groups}

- Acetamidomethyl (Acm). ${ }^{358,359}$ Removed by oxidative treatment with $\mathrm{I}_{2}$ or $\mathrm{Tl}(\mathrm{TFA})_{3}$ to form disulfide bonds or with $\mathrm{Hg}$ (II) and $\mathrm{Ag}$ (TFMSO) ${ }^{344}$ to obtain the free thiol. It is comptible with both the Boc/Bn and Fmoc/ ${ }^{t} \mathrm{Bu}$ strategies. Nevertheless, it is partially removed with HF or even TFA depending on the scavengers used. ${ }^{360,326}$ In the latter case, absence of water and use of TIS minimizes the removal. ${ }^{361}$

- Phenylacetamidomethyl (PhAcm). ${ }^{362}$ It is an analog of Acm that can be removed in similar conditions and also by treatment with the enzyme penicillin aminohydrolase. 
- tert-Butylmercapto $\left(S^{t} B u\right){ }^{363}$ It is removed with thiols (benzenethiol, $\beta$ mercaptoethanol or dithiothreitol), ${ }^{364} \mathrm{Na}_{2} \mathrm{SO}_{3}$ in $\mathrm{AcOH},{ }^{365}$ or phosphines $\left(\mathrm{PBu}_{3}\right.$ or $\mathrm{PPh}_{3}$ in $\left.\mathrm{CF}_{3} \mathrm{CH}_{2} \mathrm{OH}\right){ }^{366}$ It is compatible with the Boc and Fmoc strategies. It is partially removed with HF but completely stable to TFA and to bases like piperidine. ${ }^{367}$

- 3-Nitro-2-pyridinesulfenyl (Npys). It is removed by reducing thiols and phosphines to render the free thiol. ${ }^{368}$ It is stable to TFA and HF but it is not stable to the low-high cleavage protocol or to bases. ${ }^{369}$ It is used in the Boc/Bn strategy mainly to obtain disulfide bonds by nucleophilic displacement by the thiol of a free Cys. ${ }^{370}$

- 2-Pyridinesulfenyl (S-Pyr). ${ }^{371} \mathrm{It}$ is used in the Boc/Bn strategy and is useful when orthogonal protection of unprotected fragments is required. Ligation of a free thiocarboxylic peptide with an S-Pyr-protected $N$-terminal Cys occurs at $\mathrm{pH} 2$, the subsequent $S$ to $N$ migration at $\mathrm{pH} 7$ and final treatment with DTT renders the final ligated peptide with free Cys. S-Pyr is stable to 1 M TFMSA in TFA-anisole (10:1) at $0^{\circ} \mathrm{C}$ for $2 \mathrm{~h}$ (cleavage conditions for the MBHA resin)

- Allyloxycarbonyl (Alloc). ${ }^{163}$ It is removed with tributyltin hydride catalyzed by $\operatorname{Pd}(0)$ (usually $\left.\mathrm{Pd}\left(\mathrm{PPh}_{3}\right)_{4}\right)$. Because of its base lability, it is used only in the Boc/Bn solid phase strategy.

- $N$-allyloxycarbony- $N$-[2,3,5,6-tetrafluoro-4-(phenylthio)phenyl]] aminomethyl

(Fsam). ${ }^{372}$ It is an allyl-type protecting group that can be removed by palladium to render the free thiol both in solution and on solid phase, and is the only Cys- protecting group that allows a selective and easy release of the thiol on solid phase. It is completely stable to TFA and piperidine and can also be removed by iodine oxidation to render a disulfide bridge.

- o-Nitrobenzyl $(o N B) .{ }^{373,374}$ It is a protecting group removed by photolysis $(\lambda=300-400$ $\mathrm{nm}$ ) and is used mainly in the synthesis of caged peptides.

- 4-Picolyl. ${ }^{375}$ It is removed in solution with $\mathrm{Zn}$ dust in $\mathrm{AcOH}$ to render the free thiol. It was initially proposed for the Boc/Bn strategy but more recently has been succesfully applied to the Fmoc/tBu synthesis of dihydrooxytocin, which was further oxidized to oxytocin.

- Ninhydrin (Nin). ${ }^{376}$ It has been proposed as a protecting group for $N$-terminal Cys. It protects both the amino and the thiol groups by forming a thiazolidine. Stable to HF and TFA, it is removed with 1M Cys-OMe, 1M DIPEA in DMF for 30 min (solid phase), $10 \%$ TFA in $\mathrm{H}_{2} \mathrm{O}$ and $\mathrm{Zn}$ dust (solution) as well as by reducing thiols such as Cys in combination with tris-carboxymethylphosphine (TCEP) (solution). It is coupled to 
amines linked to the solid phase without using further protection at the amino group. Its main applications are in ligation and its combination with $\mathrm{His}(\mathrm{Bom})$ in the $\mathrm{Boc} / \mathrm{Bn}$ strategy, which prevents tiazolidine formation after Bom removal (see His protection).

\begin{tabular}{|c|c|c|c|c|}
\hline Name and Structure & Removal conditions & $\begin{array}{l}\text { Stability to } \\
\text { the removal } \\
\text { of }\end{array}$ & $\begin{array}{l}\text { Compatibility with } \\
\text { other sulfur } \\
\text { protecting groups }\end{array}$ & Ref. \\
\hline Acetamidomethyl (Acm) & $\begin{array}{l}\text { 1) } \mathrm{I}_{2}(\mathbf{S}-\mathbf{S}) \\
\text { 2) } \mathrm{Tl}(\mathrm{TFA})_{3}(\mathbf{S}-\mathbf{S}) \\
\text { 3) } \mathrm{Ag}(\mathrm{TFMSO})(\mathbf{S H}) \\
\text { 4) } \mathrm{Hg}(\mathrm{II})(\mathbf{S H})\end{array}$ & $\begin{array}{l}\text { Boc, Fmoc, } \\
\text { Alloc }\end{array}$ & $\begin{array}{l}\text { Meb/Mob, Trt, }{ }^{\text {a }} \\
\mathrm{S}^{t} \mathrm{Bu}, \mathrm{Npys}, \mathrm{Fm}{ }^{\mathrm{b}} \\
\mathrm{PhAcm}^{\mathrm{c}}\end{array}$ & $\begin{array}{l}326, \\
344, \\
358, \\
359, \\
360, \\
361\end{array}$ \\
\hline Phenylacetamidomethyl (PhAcm) & $\begin{array}{l}\text { 1) } \mathrm{Hg} \text { (II) (SH) } \\
\text { 2) penicillin } \\
\text { aminohydrolase (SH) } \\
\text { 3) } \mathrm{Tl}(\mathrm{III}) \\
\text { trifluoroacetate (S-S) } \\
\text { 4) } \mathrm{I}_{2}(\mathbf{S}-\mathbf{S})\end{array}$ & $\begin{array}{l}\text { Boc, Fmoc, } \\
\mathrm{Z}^{\mathrm{d}} \text { Alloc }\end{array}$ & $\begin{array}{l}\text { Meb/Mob, } \mathrm{S}^{t} \mathrm{Bu}, \\
\text { Npys, } \mathrm{Fm}^{\mathrm{b}}, \mathrm{Acm}^{\mathrm{c}}\end{array}$ & 362 \\
\hline $\begin{array}{c}\text { 5-tert-Butylmercapto }\left(\mathrm{S}^{t} \mathrm{Bu}\right) \\
\succ_{\mathrm{S}-}-\xi_{?}\end{array}$ & $\begin{array}{l}\text { 1) thiols (benzenethiol, } \\
\beta \text {-mercaptoethanol or } \\
\text { dithiothreitol) } \\
\text { 2) } \mathrm{Na}_{2} \mathrm{SO}_{3} \text { in } \mathrm{AcOH} \\
\text { 3) } \mathrm{PBu}_{3} \text { or } \mathrm{PPh}_{3} \text { in } \\
\mathrm{CF}_{3} \mathrm{CH}_{2} \mathrm{OH}\end{array}$ & $\begin{array}{l}\text { Boc, Fmoc, } \\
\text { Trt }\end{array}$ & $\begin{array}{l}\text { Meb/Mob, Trt, } \\
\text { Acm }\end{array}$ & $\begin{array}{l}363, \\
364, \\
365, \\
366, \\
367\end{array}$ \\
\hline 3-Nitro-2-Pyridinesulfenyl (Npys) & $\begin{array}{l}\text { 1) Thiol exchange } \\
\text { with a free Cys (S-S) } \\
\text { 2) Reducing thiols } \\
\text { (SH) } \\
\text { 3) } \mathrm{PBu}_{3}\left(1 \text { eq.), } \mathrm{H}_{2} \mathrm{O}\right. \\
\text { (SH) }\end{array}$ & $\begin{array}{l}\text { Boc, Z, }{ }^{\mathrm{d}} \text { Trt, } \\
\text { Alloc }\end{array}$ & $\begin{array}{l}\text { Meb/Mob, Trt, } \\
\text { Acm }\end{array}$ & $\begin{array}{l}368 \\
369 \\
370\end{array}$ \\
\hline 2-Pyridinesulfenyl (S-Pyr) & $\begin{array}{l}\text { Thiocarboxylic acids } \\
\text { and DTT (SH) }\end{array}$ & Boc & $\begin{array}{l}\text { Meb/Mob, Trt, } \\
\text { Acm }\end{array}$ & 371 \\
\hline
\end{tabular}




\begin{tabular}{|c|c|c|c|}
\hline Allyloxycarbonyl (Alloc) & $\begin{array}{l}\mathrm{Pd}\left(\mathrm{PPh}_{3}\right)_{4}, \mathrm{Bu}_{3} \mathrm{SnH} \\
(\mathbf{S H})\end{array}$ & Boc, Trt & 163 \\
\hline $\begin{array}{c}\text { N-allyloxycarbony- } \mathrm{N}-[2,3,5,6- \\
\text { tetrafluoro-4-(phenylthio)phenyl]] } \\
\text { aminomethyl (Fsam) }\end{array}$ & $\begin{array}{l}\text { 1) } \mathrm{Pd}(0) \text {, scavengers } \\
\text { (i.e. } \mathrm{PdCl}_{2}\left(\mathrm{PPh}_{3}\right)_{2} \text {, } \\
\mathrm{Bu}_{3} \mathrm{SnH}_{\text {or }} \mathrm{Pd}\left(\mathrm{PPh}_{3}\right)_{4} \text {, } \\
\left.\mathrm{PhSiH}_{3}\right) \\
\text { 2) } \mathrm{I}_{2}(\mathrm{~S}-\mathrm{S})\end{array}$ & & 372 \\
\hline o-Nitrobenzyl (oNB) & $\begin{array}{l}\text { Photolysis }(\lambda=300- \\
400 \mathrm{~nm})\end{array}$ & $\begin{array}{l}\text { Boc, Fmoc, } \\
\text { Trt, } Z^{\mathrm{e}}\end{array}$ & $\begin{array}{l}373, \\
374\end{array}$ \\
\hline 4-Picolyl & $\mathrm{Zn}$ dust in $\mathrm{AcOH}(\mathbf{S H})$ & Boc, Fmoc & 375 \\
\hline Ninhydrin (Nin) & $\begin{array}{l}\text { 1) } 1 \mathrm{M} \text { Cys-OMe, } 1 \mathrm{M} \\
\text { DIPEA in DMF (solid } \\
\text { phase) } \\
\text { 2) } 10 \% \text { TFA in } \mathrm{H}_{2} \mathrm{O} \\
\text { and } \mathrm{Zn} \text { dust (solution) } \\
\text { 3) Reducing thiols } \\
\text { such as Cys in } \\
\text { combination with } \\
\text { TCEP (solution) }\end{array}$ & $\mathrm{Z},{ }^{\mathrm{d}}$ Boc & 376 \\
\hline
\end{tabular}

${ }^{a}$ The Trt should be removed first with TFA solutions

${ }^{\mathrm{b}}$ The Fm should be removed first

${ }^{\mathrm{c}}$ The PhAcm should be removed first enzymatically

${ }^{\mathrm{d}}$ Except catalytical hydrogenation removal.

${ }^{\mathrm{e}} \mathrm{HF} / \mathrm{anisole}$ removal.

The mercaptopropionic acid (des-amino Cys), which acts as an $N$-terminal capping in some peptides of therapeutic interest, can be introduced as a dimer. The free thiol is obtained after reduction with $\beta$-mercaptoethanol or $\mathrm{Bu}_{3} \mathrm{P}^{377}$ 


\section{METHIONINE (Met)}

\subsection{General}

The thioether funcionality of Met (Figure 22) can undergo two side reactions, oxidation to sulfoxide and $S$-alkylation. The latter can lead to the formation of homoserine lactone in $C$-terminal Met (Figure 2). ${ }^{378}$ These side reactions are favoured in acidic conditions.

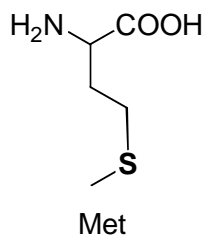

Figure 22. Methionine (Met)

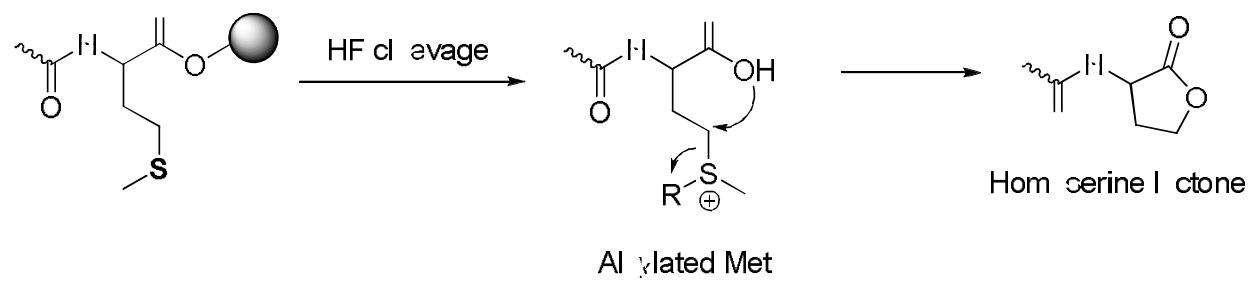

Figure 23. Homoserine lactone formation after Met alkylation during HF cleavage in the Boc/Bn solid phase strategy.

In the Fmoc/t $\mathrm{Bu}$ strategy, Met is used unprotected in most of the cases. To prevent oxidation during amino acid side-chain deprotection and cleavage from the resin, ethylmethylsulfide or thioanisole are used. ${ }^{379,380}$

In contrast, in the Boc/Bn strategy, free Met may not be the best option because of the strong acidic conditions applied mainly in the cleavage from the resin but also in the removal of the Boc group. Therefore, very frequently, $N^{\alpha}$-Boc protected Met sulfoxide is directly used and is reduced at the end of the synthesis.

\subsection{Introduction of the protecting groups}

The sulfoxide derivatives of Met are commercially available and can be prepared via oxidation with $\mathrm{H}_{2} \mathrm{O}_{2}{ }^{381}$

\subsection{Removal: sulfoxide reduction}


In the case of SPS, the reduction of $\operatorname{Met}(\mathrm{O})$ can be performed either during the cleavage or after it. In the latter case, the sulfoxide funcionality confers extra polarity to protected peptides, which facilitates its purification; however, it must be taken into consideration that sulfoxides are chiral and therefore different diastereomers will be observed.

Several reduction methods have been used:

1) Reduction during the low-high HF or TFMSA cleavage in the Boc/Bn strategy.

DMS and $p$-thiocresol or anisole should be used as scavengers to prevent $S$-alkylation.

2) $N$-methylmercaptoacetamide in $10 \%$ aquous acetic acid. ${ }^{382,383,384}$ It requires long reaction times and disulfide bridges may be reduced.

3) TFA-NH 4 I-DMS. ${ }^{385,386,387}$ This method of reduction does not affect disulfide bridges and if there are free Cys residues, a disulfide bridge is formed during the reduction of the Met sulfoxide. tert-Butyl-type groups are removed during the reduction. Dimerization of Trp (see Trp section) can occur in the case of long reaction times as a result of overexposure to acidic conditions.

4) $\mathrm{TiCl}_{4}$ (3 eq.)- $\mathrm{NaI}$ (6 eq.) in MeOH-acetonitrile-DMF (5:5:4). ${ }^{388}$ Although a very fast reduction method, it can also lead to reduction of disulfide bridges or oxidation of Trp, the latter caused by the $\mathrm{I}_{2}$ generated in the sulfoxyde reduction.

5) TFA-TMSBr-EDT. ${ }^{389,390}$ In this method the reduction is carried out by addition of TMSBr and EDT at the end of the cleavage step. It appears to be compatible with Trpcontaining peptides. The peptide is isolated by precipitation in diethylether.

6) $\mathrm{Bu}_{4} \mathrm{NBr}$ in TFA. It is an alternative to method 5 in which the reduction is also carried out during the cleavage step. ${ }^{391}$

7) Sulfur trioxide (5 eq.), EDT (5 eq.) in pyridine-DMF (2:8) ${ }^{392}$ In this method protection of hydroxyl groups is required to prevent sulfonylation.

\section{Met des-tert-butylation.}

If tert-butylation occurs during the global deprotection step, reversion to the free Met residue is accomplished by heating a solution of the peptide in $4 \% \mathrm{AcOH}_{(\text {aq) }}$ at $60-65$ ${ }^{\circ} \mathrm{C} .{ }^{393,394}$ 


\section{HISTIDINE (HIS)}

\subsection{General}

The imidazole ring of His (Figure 24) has two nucleophilic points, the $\pi$ and $\tau$ nitrogens. ${ }^{395}$

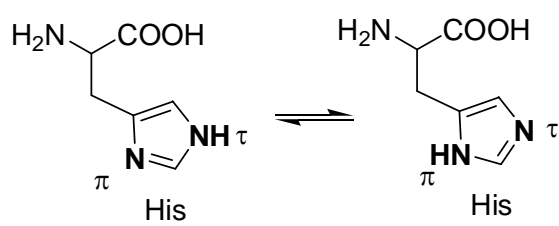

Figure 24. Histidine (His) tautomers.

Unprotected His is highly prone to racemization during the coupling (Figure 25) and acylation during peptide synthesis followed by $N^{\tau}$ to $\alpha$-amino migration (Figure 26). ${ }^{396,397}$

The basic and nucleophilic $\pi$-nitrogen is the one involved in racemization mechanisms and can be masked in two ways: (i) direct protection (ii) $\tau$-nitrogen protection with bulky or electron-withdrawing protecting groups which reduce the basicity of the $\pi$ nitrogen

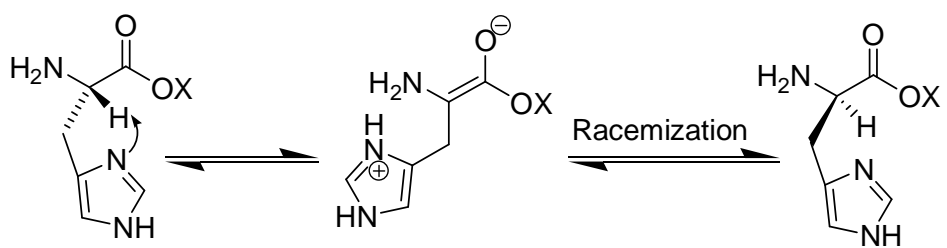

Figure 25. Proposed racemization mechanism of His during the coupling step. Adapted from 398)

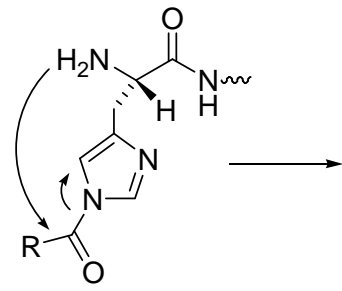

Acylated His<smiles>[Y]NC(=O)[C@H](C)NC([R])=O</smiles>

Terminated peptide

Figure 26. $N^{\tau}$ to $\alpha$-amino migration after acylation of His during peptide synthesis 
Although a large number of protecting groups have been tested for His side chain protection, either in the $\pi$ or the $\tau$-nitrogen, the problem has still not been fully resolved, the situation being more critical in the case of the Boc/Bn solid phase strategy.

The most used protecting groups are $\mathrm{Trt}$ for the Fmoc/t $\mathrm{Bu}$ solid phase strategy and Dnp (2,4-dinitrophenyl), Bom (benzyloxymethyl) and Tos (tosyl) for the Boc/Bn solid phase strategy.

\subsection{Introduction of the protecting groups ${ }^{395}$}

Protection of the imidazole ring of His requires $\alpha$-amino, and carboxylic acid protection with orthogonal protecting groups. In cases such as Trt, the $\alpha$-amino group can be used unprotected and at the end of the synthesis the $N^{\alpha}$-trityl is removed, thereby leaving the $N^{\text {im }}$-trityl unalterated. Generally, the reaction of the imidazole ring of His with the corresponding active species (halides in general) gives the $N^{\tau}$-protected imidazole as a majoritary and sometimes single product. Nevertheless, $N^{\pi}$ protection is preferred because, as previously mentioned, the $N^{\pi}$ is the one directly involved in His racemization. Thus, when possible, $N^{\pi}$-Protection is performed by masking the $\tau$ nitrogen with an orthogonal protecting group, which is removed at the end of the synthesis of the derivative.

\subsection{Removal}

\subsubsection{Protecting groups removed by acid}

\section{$\underline{N^{\tau} \text {-protection }}$}

- $N^{\tau}$-Tosyl (Tos). ${ }^{399}$ It is removed with HF. It minimizes racemisation by reducing the basicity of the $N^{\pi}$ by inductive effect and also because of steric hindrance. Although it is still quite commonly used in the Boc/Bn solid phase strategy, it is unstable in the presence of $N^{\alpha}$ groups and HOBt. ${ }^{400,396}$

- $N^{\tau}$-Trityl (Trt): It is the usual protecting group for the Fmoc/t $\mathrm{Bu}$ strategy. ${ }^{20,401}$ It is removed with 95\% TFA but is much less acid-labile than the $N^{\alpha}$-trityl group and cannot be selectively removed in the presence of ${ }^{t} \mathrm{Bu}$ groups. ${ }^{402} \mathrm{Using} N^{\tau}$ protection, the free $N^{\pi}$ can still catalyze racemization. However, the bulkiness of the Trt group minimizes this side reaction in most cases but it is still critical in particular cases such as the formation of ester bonds or when the amino component is sterically hindered. ${ }^{395}$

- $N^{\tau}$-Methyltrityl (Mtt) and $N^{\tau}$-monomethoxytrityl (Mmt). These are more acid-labile derivatives of the Trt group, they are removed with $15 \%$ and 5\% TFA in DCM, $1 \mathrm{~h} .{ }^{402}$ - $N^{\tau}$-tert-butyloxycarbonyl (Boc). It is only useful for the synthesis of short sequences via Fmoc chemistry because of its instability to prolonged piperidine treatments. ${ }^{401}$ Its 
slightly greater acid stability compared with Trt makes it highly suitable for the preparation of His-containing protected peptides using a $\mathrm{ClTrtCl}$ resin.

- $N^{t}$-2,4-Dimethylpent-3-yloxycarbonyl (Doc). ${ }^{403}$ It is removed with liquid HF and is used in the Boc/Bn solid phase strategy. In contrast to other proposed carbamate-type His-protecting groups, it is very resistant to nucleophiles because of its bulkiness, thereby preventing $N^{\mathrm{im}}$ to $N^{\alpha}$ transfer. It is not stable to $2 \%$ hydrazine in DMF but is more stable to piperidine than the 2,4-dinitrophenyl (Dnp) group (see "other protecting groups") (its half life in $20 \%$ piperidine in DMF is $84 \mathrm{~h}$ ).

$\underline{N^{\pi} \text {-protection }}$

- $N^{\pi}$-Benzyloxymethyl (Bom). It is removed by HF, TFMSA or hydrogenolysis and is completely stable to bases and nucleophyles. It has been extensively used for the Boc/Bn solid phase strategy. As formaldehyde is released during Bom cleavage, appropiate scavengers should be used to prevent formylation, methylation or the formation of thiazolidines when an $N$-terminal Cys is present. ${ }^{327,328}$ In addition, a recent report shows that $\alpha$-amino Boc removal of Bom-protected His requires harsher conditions than those commonly used. ${ }^{404}$

- $N^{\pi}$-tert-Butoxymethyl (Bum). ${ }^{405,406}$ It is removed by TFA and resistant to hydrogenolysis. Formylation during its removal can be prevented using appropiate scavengers in the same way as for Bom. It prevents racemization of His in the Fmoc/t $\mathrm{Bu}$ strategy; however, it is not widely used because of the difficult synthesis of Fmoc$\operatorname{His}(\pi$-Bum)-OH.

\begin{tabular}{|l|l|l|c|}
\hline Name and Structure & Removal conditions & $\begin{array}{c}\text { Stability to the } \\
\text { removal of }\end{array}$ & Ref \\
\hline$N^{\tau}$-tosyl (Tos) & HF, scavengers & Boc, Trt & 396, \\
\hline
\end{tabular}




\begin{tabular}{|c|c|c|c|}
\hline$N^{\tau}$-Monomethoxytrityl (Mtt) & $15 \%$ TFA, DCM, $1 \mathrm{~h}$ & Fmoc, Alloc & 402 \\
\hline$N^{\tau}$-methyltrityl (Mmt) & $5 \%$ TFA, DCM, $1 \mathrm{~h}$ & Fmoc, Alloc & 402 \\
\hline$N^{\tau}$-tert-butyloxycarbonyl (Boc) & TFA, scavengers & Fmoc, ${ }^{\mathrm{a}}$ Alloc & 401 \\
\hline $\begin{array}{c}N^{\tau} \text {-2,4-dimethylpent-3-yloxycarbonyl } \\
\text { (Doc) }\end{array}$ & HF, scavengers & Boc, $Z$, ${ }^{\mathrm{b}}$ Trt & 403 \\
\hline$N^{\pi}$-benzyloxymethyl (Bom) & $\begin{array}{l}\text { 1) HF, scavengers } \\
\text { 2) TFMSA-TFA } \\
\text { 3) Catalytical } \\
\text { Hydrogenation }\end{array}$ & Boc, Fmoc, ${ }^{\mathrm{c}}$ Trt & $\begin{array}{l}327, \\
328, \\
404\end{array}$ \\
\hline$N^{\pi}$-tert-butoxymethyl (Bum) & TFA, scavengers & Fmoc, $Z^{b}$ & $\begin{array}{r}395 \\
396\end{array}$ \\
\hline
\end{tabular}

${ }^{\mathrm{a}}$ Only stable to a few Fmoc removal cycles (partially labile to piperidine).

${ }^{\mathrm{b}}$ Catalytical hydrogenation removal.

${ }^{\mathrm{c}}$ Except catalytical hydrogenation removal.

\subsubsection{Protecting group removed by base}

$N^{\tau}$-9-Fluorenylmethoxycarbonyl (Fmoc). ${ }^{407}$ It is removed with piperidine-DMF (2:8) and has been used for the synthesis of peptide-oligonucleotide conjugates. ${ }^{234}$ $N^{\tau}$-2,6-Dimethoxybenzoyl (Dmbz). ${ }^{408}$ It is a relatively recently developed protecting group for the Fmoc/t'Bu strategy and therefore it has not been widely used. Removed with ammonia solutions and stable to the removal of tert-butyl type groups, it 
minimizes His racemization during the coupling to the same extent as Trt and also reduces acyl migration.

\begin{tabular}{|l|l|l|l|}
\hline Name and Structure & Removal conditions & $\begin{array}{l}\text { Stability to the } \\
\text { removal of }\end{array}$ & Ref \\
\hline 9-Fluorenylmethoxycarbonyl (Fmoc) & Piperidine-DMF (2:8) & Boc & 234 \\
& & & \\
\hline 2,6-Dimethoxybenzoyl (Dmbz) & $\begin{array}{l}\text { 1) } 32 \% \mathrm{NH}_{3(\mathrm{aq})^{-}} \\
\text {dioxane }(1: 1), 6 \mathrm{~h} .\end{array}$ & Boc, Fmoc, Trt & 408 \\
& 2) $32 \% \mathrm{NH}_{3(\mathrm{aq})}-\mathrm{EtOH}$ & & \\
(3:1), $2 \mathrm{~h}$. & & \\
\hline
\end{tabular}

\subsubsection{Other protecting groups}

- $N^{\tau}$-2,4-Dinitrophenyl (Dnp). ${ }^{409}$ It is removed by thiolysis, ${ }^{410,411}$ and is stable to HF. It is also commonly used in the $\mathrm{Boc} / \mathrm{Bn}$ solid phase strategy. However, it also has some drawbacks: incomplete removal can occur in sequences rich in His and it is labile to nucleophiles. These features makes it incompatible with Lys(Fmoc) because after Fmoc removal the Dnp group can migrate to the free amino of the Lys. ${ }^{412}$ In addition, it must be removed before eliminating the last $\alpha$-Boc group. ${ }^{413}$

\begin{tabular}{|c|l|l|l|}
\hline Name and Structure & Removal conditions & $\begin{array}{c}\text { Stability to the } \\
\text { removal of }\end{array}$ & \multicolumn{1}{|c|}{ Ref. } \\
\hline $\boldsymbol{N}^{\tau}$-2,4-dinitrophenyl (Dnp) & $\begin{array}{l}\text { Thiolysis (e.g. } \\
\text { thiophenol, DBU) }\end{array}$ & Boc, $\mathrm{Z},{ }^{\mathrm{a}} \mathrm{Trt}$ & 409,410, \\
& & & 411,412, \\
\hline
\end{tabular}

${ }^{\mathrm{a}}$ Except catalytical hydrogenation removal. 


\section{SERINE (Ser), THREONINE (Thr) AND HYDROXYPROLINE (Hyp)}

\subsection{General}

Amino acids containing unprotected hydroxyl funcionalities such as Ser, Thr and Hyp (Figure 27) can undergo side reactions such as dehydratation or $O$-acylation followed by $O-N$ migration after amino deprotection (Figure 28).<smiles>NC(CO)C(=O)O</smiles>

Ser<smiles>CC(O)C(N)C(=O)O</smiles>

Thr<smiles>O=C(O)C1CC(O)CN1</smiles>

Hyp

Figure 27. Serine (Ser), Threonine (Thr) and Hydroxyproline (Hyp).<smiles>[R]C([R])=O</smiles><smiles>[R]OC(=O)OCC(NC(C)=O)C(=O)O</smiles><smiles>CC1CCC(C(=O)O)CN1</smiles><smiles>[R]C(=O)NC(CO)C(=O)O</smiles>

Figure 28. $O$-acylation followed by $O-N$ migration after amino deprotection. (1) $O$ acylation (2) Amino protecting group (PG) removal (3) $O-N$ migration.

Although, the protected derivatives are the safest way to incorporate Ser, Thr or Hyp into the peptide sequence, they can also be used with the free hydroxyl functionality. Protection is more necessary in SPS because an excess of acylating agents is used, and for Ser, whose primary alcohol is more prone to acylation than the secondary alcohols of Thr and Hyp, which have been successfully used without protection in several syntheses, including solid phase. ${ }^{414,415}$ Nevertheless, there are also some reports of the succesful use of unprotected Ser in solution phase synthesis, but care must be taken when choosing the activating agents. ${ }^{416,417}$

In peptide synthesis, hydroxyl funcionalities are protected as ethers, which are more stable than the corresponding carbamates and esters. The most used protecting groups for the $\mathrm{Boc} / \mathrm{Bn}$ and $\mathrm{Fmoc} /{ }^{t} \mathrm{Bu}$ strategies are $\mathrm{Bn}$ (benzyl) and ${ }^{t} \mathrm{Bu}$ (tert-butyl) respectively.

\subsection{Introduction of the protecting groups}

Distinct protection methods are used depending on the kind of protecting group. 
${ }^{t} \mathrm{Bu}$ protection is carried out via addition of isobutylene in acidic conditions. ${ }^{418} \mathrm{Bn}$ protection is performed using benzyl bromide in basic conditions in the case of Ser, ${ }^{419,420}$ and reaction with benzyl alcohol in acidic medium in the case of $\mathrm{Thr}^{421}$

$\mathrm{Bn}$ and ${ }^{t} \mathrm{Bu}$ protections can also be achieved via formation of 2,2-difluoro-1,3,2oxazaborolidin-5-ones by reaction of the lithium salt of Ser or the sodium salt of Thr with $\mathrm{BF}_{3}$. Treatment with isobutylene ( ${ }^{t} \mathrm{Bu}$ protection) or benzyl 2,2,2trichloroacetimidate (Bn protection) followed by a base treatment to destroy the 2,2difluoro-1,3,2-oxazaborolidin-5-one generates the desired protected derivatives. ${ }^{422} \mathrm{Trt}$ and alkylsilane protection are achieved using the respective chlorides in the presence of a base. ${ }^{423,424}$

\subsection{Removal}

12.3.1. Protecting groups removed by acid- Benzyl $(B n) .{ }^{425}$ It is removed with HF in the presence of scavengers, and is the most used protecting group for Ser and Thr in the Boc/Bn solid phase strategy. When many benzyl ethers are present, appropiate scavengers should be used to avoid benzylation of free amino acid side chains.

- Cyclohexyl $(\mathrm{CH} x){ }^{426}$ It is an alternative to the benzyl group for the protection of Ser in the Boc/Bn solid phase strategy. It is more stable to acids and completely stable to catalytical hydrogenation. However, it has not been widely used.

- tert-Butyl $\left({ }^{t} B u\right) .{ }^{418}$ It is removed with TFA and used mainly in the Fmoc $/{ }^{t} \mathrm{Bu}$ solid phase strategy. ${ }^{t} \mathrm{Bu}$ ethers are less acid-labile than the Boc group and some reports indicate that they can be used even as temporary protecting groups in the Boc/Bn solid phase strategy. ${ }^{427}$

- Trityl (Trt). ${ }^{423}$ It is removed with 1\% TFA. It has been shown that the same peptide with all the hydroxyl groups protected by $\operatorname{Trt}$ or ${ }^{t} \mathrm{Bu}$ is obtained with better purity in the case of the former. ${ }^{428}$

- tert-Butyldimethylsilyl (TBDMS). ${ }^{424}$ It is more acid-labile than the ${ }^{t} \mathrm{Bu}$ group and can be removed selectively in the presence this group using $\mathrm{AcOH}-\mathrm{THF}-\mathrm{H}_{2} \mathrm{O}$ (3:1:1) or TBAF.

- Pseudoprolines: See amide backbone protection. 


\begin{tabular}{|c|c|c|c|}
\hline Name and Structure & Removal conditions & $\begin{array}{l}\text { Stability to the } \\
\text { removal of }\end{array}$ & Ref. \\
\hline Benzyl (Bn) & $\begin{array}{l}\text { 1) HF, scavengers } \\
\text { 2) TFMSA-TFA }\end{array}$ & $\begin{array}{l}\text { Boc, Fmoc, Trt, } \\
\text { Alloc, } p \mathrm{NZ}^{\mathrm{a}}\end{array}$ & 425 \\
\hline Cyclohexyl $(\mathrm{cHx})$ & TFMSA-TFA & $\begin{array}{l}\text { Boc, Fmoc, Trt, } \\
\text { Alloc, } p \mathrm{NZ}\end{array}$ & 426 \\
\hline $\begin{array}{c}\text { tert-Butyl }\left({ }^{t} \mathrm{Bu}\right) \\
\downarrow_{\xi}\end{array}$ & 90\% TFA-DCM & $\begin{array}{l}\text { Fmoc, } \mathrm{Z}^{\mathrm{b}} \\
\text { Alloc, } p \mathrm{NZ}\end{array}$ & $\begin{array}{l}418, \\
427\end{array}$ \\
\hline Trityl (Trt) & $1 \%$ TFA-DCM & Fmoc, Alloc & $\begin{array}{l}423 \\
428\end{array}$ \\
\hline $\begin{array}{l}\text { tert-Butyldimethylsilyl (TBDMS) } \\
\qquad \mathrm{S}_{\mathrm{S}} \mathrm{S}_{\mathrm{i}}\end{array}$ & $\begin{array}{l}\text { 1) TFA } \\
\text { 2) } \mathrm{AcOH}-\mathrm{THF}-\mathrm{H}_{2} \mathrm{O} \\
(3: 1: 1), 18 \mathrm{~h} \text { (Ser), } 2 \\
\text { h (Thr) } \\
\text { 3) } 0.1 \mathrm{M} \text { TBAF in } \\
\text { DMF, 2h (Ser), } 18 \mathrm{~h} \\
\text { (Thr) }\end{array}$ & Fmoc & 424 \\
\hline Pseudoprolines & $\begin{array}{l}95 \% \text { TFA and } \\
\text { scavengers }\end{array}$ & Fmoc, Alloc & \\
\hline
\end{tabular}

${ }^{\mathrm{a}}$ Except catalytical hydrogenation removal.

${ }^{\mathrm{b}}$ Catalytical hydrogenation removal.

\subsubsection{Other protecting groups}

- tert-Butyldimethylsilyl (TBDMS). See protecting groups removed by acid.

- tert-Butyldiphenylsilyl (TBDPS). ${ }^{429,430}$ It is typically removed by TBAF but also by 2 $\mathrm{M} \mathrm{NaOH}_{(\mathrm{aq})} \mathrm{EtOH}(1: 1)$. It is more acid-stable than TBDMS and stable to the removal of $N$-Trt, $O$-Trt, $O$-TBDMS and Boc. 
- 4,5-Dimethoxy-2-nitrobenzyloxycarbonyl (Dmnb). ${ }^{431}$ It is a photolabile protecting group analogous to the corresponding Dmnb ester. Ser(Dmnb) has been used recently to control protein phosporyltion. ${ }^{432}$

- Propargyloxycarbonyl (Poc) ${ }^{433} \mathrm{It}$ is removed with $\left[\left(\mathrm{PhCH}_{2} \mathrm{NEt}_{3}\right)_{2} \mathrm{MoS}_{4}\right]$ in $\mathrm{AcCN}, 1 \mathrm{~h}$, rt. These removal conditions do not affect Boc, Z, methyl or benzyl esters, It has recently been applied to the protection of Ser and Thr for peptide synthesis in solution.

\begin{tabular}{|c|c|c|c|}
\hline Name and Structure & Removal conditions & $\begin{array}{l}\text { Stability to the } \\
\text { removal of }\end{array}$ & Ref. \\
\hline tert-Butyldiphenylsilyl (TBDPS) & $\begin{array}{l}\text { 1) } 1 \mathrm{M} \mathrm{TBAF}(2-3 \\
\text { eq.), THF, } 1-5 \mathrm{~h} \\
\text { 2) } 2 \mathrm{M} \mathrm{NaOH}_{\text {(aq) }} \mathrm{EtOH} \\
(1: 1), 7 \mathrm{~h}\end{array}$ & Boc, Fmoc, Trt & $\begin{array}{l}429, \\
430\end{array}$ \\
\hline $\begin{array}{l}\text { 4,5-Dimethoxy-2-nitrobenzyloxycarbonyl } \\
\text { (Dmnb) }\end{array}$ & $\begin{array}{l}\text { Photolysis (visible } \\
\text { blue light) }\end{array}$ & Boc, Fmoc, Trt & $\begin{array}{l}431, \\
432\end{array}$ \\
\hline $\begin{array}{c}\text { Propargyloxycarbonyl (Poc) } \\
=\end{array}$ & $\begin{array}{l}{\left[\left(\mathrm{PhCH}_{2} \mathrm{NEt}_{3}\right)_{2} \mathrm{MoS}_{4}\right]} \\
\text { in } \mathrm{AcCN}, 1 \mathrm{~h} .\end{array}$ & Boc, Fmoc, Trt & \\
\hline
\end{tabular}




\section{TYROSINE (Tyr)}

\subsection{General}

Use of unprotected Tyr (Figure 29) can lead to acylation of the phenol group because of the nucleophilicity of the phenolate ion under basic conditions. In addition, the electronrich aromatic ring can undergo alkylation at the ortho position.

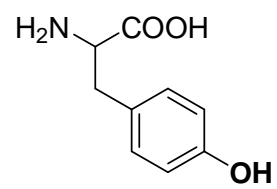

Tyr

Figure 29. Tyrosine (Tyr)

The acidity of phenol group makes alkyl-type protecting groups less stable than in the case of Ser, Thr and Hyp. The most used Tyr-protecting groups for the Boc/Bn and Fmoc $/^{t} \mathrm{Bu}$ solid phase strategies are $\mathrm{Bn}$ and ${ }^{t} \mathrm{Bu}$ group, respectively.

\subsection{Introduction of the protecting groups}

To protect the phenolic function of Tyr, ${ }^{346}$ both the amino and carboxylic groups must be protected either by forming a copper (II) chelate or using orthogonal protecting groups.

${ }^{t} \mathrm{Bu}$-protected Tyr is obtained using isobutylene in acidic medium, ${ }^{418}$ whereas with the other Tyr-protected derivatives the corresponding alkyl halide is used as the protecting agent. ${ }^{434,435}$

\subsection{Removal}

\subsubsection{Protecting groups removed by acid}

- Benzyl (Bn). It is removed with HF, but can lead to benzylation of the aromatic ring of Tyr, and it is not stable enough to the repetitive treatments with 50\% TFA in DCM to remove the Boc group. ${ }^{436}$ Milder removal conditions for the Boc group allow the synthesis of long peptides using benzyl protection. ${ }^{26}$ In solution synthesis it is usually removed by catalytic hydrogenation.

- tert-Butyl $\left({ }^{t} B u\right)$. It is removed with TFA and is the most used protecting group for the Fmoc/ ${ }^{t} \mathrm{Bu}$ strategy solid phase strategy. It is more stable than the tert-butyl ethers of Ser, Thr and Hyp. It is also stable to fluoride ions (TBAF) ${ }^{277}$

- 2,6-Dichlorobenzyl $(D c b) .{ }^{434}$ It is removed with HF and because of its major acid stabitlity it is an alternative to the Benzyl group for the Boc/Bn solid phase strategy. 
- 2-Bromobenzyl $(\mathrm{BrBn}) .^{437}$ It is another more acid-stable derivative of the benzyl group; however, it has not found as wide application as Dcb.

- Benzyloxycarbonyl $(Z){ }^{338}$ It is removed with $\mathrm{HF}$, and protects the phenol funtionalilty by forming a carbonate. Although still used, it is too acid-labile to withstand repetitive treatments with 50\% TFA to remove the Boc group.

- 2-Bromobenzyloxycarbonyl (BrZ). ${ }^{434,435}$ It protects the phenol funcionalilty by forming a carbonate but unlike with other carbonates, only minor amounts of $O$ to $N$ transfer are observed. In contrast to the above mentioned $\mathrm{Z}$ group, $\mathrm{BrZ}$ is very stable to acidic conditions (removed with HF) and widely used for the SPS of long peptides using the Boc/Bn solid phase strategy. ${ }^{434,435}$ It cannot be used in the Fmoc/t Bu strategy because being a carbonate it is very sensitive to bases and nucleophiles. ${ }^{438}$

- 3-Pentyl (Pen). ${ }^{439}$ It is a relatively new protecting group, stable to $50 \%$ TFA, bases and catalytic hydrogenation and readily removed with HF.

- tert-Butyloxycarbonyl (Boc). ${ }^{440}$ This carbonate has been used occassionally for Tyr side chain protection in the Boc/Bn solid phase strategy but only protects the phenol during the coupling and is removed with TFA along to $N^{\alpha}$-Boc.

- Trityl (Trt) and 2-Chlorotrityl (2-Cl-Trt). They are very acid-labile and have the advantage of the low electrophilicity of trityl cations. Thus, they are a better alternative to ${ }^{t} \mathrm{Bu}$ for the synthesis of peptides containing residues prone to alkylation such as Trp and Met. ${ }^{423,441,428}$ Removal is carried out with $2 \%$ TFA in DCM ${ }^{294}$

- tert-Butyldimethylsilyl (TBDMS). ${ }^{424}$ Unlike the ${ }^{t} \mathrm{Bu}$ ethers, the TBDMS ether of Tyr is more acid-labile than the corresponding ${ }^{t} \mathrm{Bu}$ ethers; however, it can be removed selectively with TBAF.

- 4-(3,6,9-trioxadecyl)oxybenzyl (TEGBz or TEGBn). See 5.3.1.

\begin{tabular}{|c|l|l|c|}
\hline Name and Structure & Removal conditions & $\begin{array}{l}\text { Stability to the } \\
\text { removal of }\end{array}$ & Ref. \\
\hline Benzyl $(\boldsymbol{B n})$ & $\begin{array}{l}\text { 1) } \mathrm{HF} \text { and scavengers } \\
\text { 2) } \mathrm{H}_{2} \text { cat. }\end{array}$ & $\begin{array}{l}\text { Boc, Fmoc, Trt, } \\
\text { Alloc, } p \mathrm{NZ}^{\text {a }}\end{array}$ & $\begin{array}{c}26, \\
436\end{array}$ \\
\hline tert-Butyl $\left({ }^{t} \mathrm{Bu}\right)$ & $35 \%$ TFA-DCM & $\begin{array}{l}\text { Fmoc, } \mathrm{Z}^{\mathrm{b}}, \\
\text { Alloc, Trt, } p \mathrm{NZ}\end{array}$ & 277 \\
\hline & & & \\
\hline
\end{tabular}




\begin{tabular}{|c|c|c|c|}
\hline 2,6-Dichlorobenzyl (Dcb) & $\mathrm{HF}$ and scavengers & $\begin{array}{l}\text { Boc, Fmoc, Trt, } \\
\text { Alloc, } p \mathrm{NZ}^{\mathrm{a}}\end{array}$ & 434 \\
\hline $\begin{array}{c}\text { 2-Bromobenzyl (BrBn) } \\
\mathrm{Br}\end{array}$ & $\mathrm{HF}$ and scavengers & $\begin{array}{l}\text { Boc, Fmoc, Trt, } \\
\text { Alloc, } p \mathrm{NZ}^{\mathrm{a}}\end{array}$ & 437 \\
\hline Benzyloxycarbonyl $(Z)$ & $\mathrm{HF}$ and scavengers & Boc, Trt & 338 \\
\hline $\begin{array}{c}\text { 2-Bromobenzyloxycarbonyl (BrZ) } \\
\mathrm{Br}\end{array}$ & HF and scavengers & Boc, Trt & $\begin{array}{l}434, \\
435, \\
438\end{array}$ \\
\hline 3-Pentyl (Pen) & HF and scavengers & $\begin{array}{l}\text { Boc, Fmoc, Z, } \\
\text { Trt }\end{array}$ & 439 \\
\hline tert-Butyloxycarbonyl (Boc) & TFA-DCM & & 440 \\
\hline Trityl (Trt) & $2 \%$ TFA-DCM & Fmoc, Alloc & $\begin{array}{l}294, \\
423, \\
428, \\
441\end{array}$ \\
\hline 2-Chlorotrityl (2-Cl-Trt) & $2 \%$ TFA in DCM & Fmoc, Alloc & $\begin{array}{l}294, \\
423, \\
428, \\
441\end{array}$ \\
\hline $\begin{array}{c}\text { tert-Butyldimethylsilyl (TBDMS) } \\
\qquad \sum_{S i}^{\prime}-\xi\end{array}$ & $\begin{array}{l}\text { 1) } 35 \% \text { TFA } \\
\text { 2) } 0.1 \mathrm{M} \text { TBAF-DMF, } \\
15 \mathrm{~min} .\end{array}$ & Fmoc & 424 \\
\hline $\begin{array}{l}\text { 4-(3,6,9-trioxadecyl)oxybenzyl (TEGBz } \\
\text { or TEGBn) }\end{array}$ & TFA-DCM & Fmoc, Trt & \\
\hline
\end{tabular}


${ }^{\mathrm{b}}$ Catalytical hydrogenation removal. 


\subsubsection{Other protecting groups}

- Benzyl (Bn). See protecting groups removed by acid.

- tert-Butyldimethylsilyl (TBDMS). See protecting groups removed by acid.

- Allyl (Al). ${ }^{442,97,163}$ Removed with Pd (0), it is strictly orthogonal to the most common protecting groups. It is used both in solution strategies and SPS.

- o-Nitrobenzyl $(o N B) .{ }^{443}$ A photolabile protecting group, it has the same properties as the $o N B$ ester. It has been used for the synthesis of Tyr caged peptides. ${ }^{444}$

- Propargyloxycarbonyl (Poc).433 (MATEIXA QUE POC, SER, P82) It is removed with $\left[\left(\mathrm{PhCH}_{2} \mathrm{NEt}_{3}\right)_{2} \mathrm{MoS}_{4}\right]$ in AcCN, 1h, rt. These removal conditions do not affect Boc, $\mathrm{Z}$, methyl or benzyl esters, It has recently been applied to the protection of Tyr for peptide synthesis in solution.

- Boc-N-methyl-N-[2-(methylamino)ethyl]carbamoyl (Boc-Nmec). ${ }^{445}$ It is a recently developed protecting group (see also Boc-Nmec-Hmb in 6.3.2). After removal of the Boc group the Nme moiety is removed with $N$-methylmorpholine (10 eq) in DMF/ $\mathrm{H}_{2} \mathrm{O}$ (3:7), $4 \mathrm{~h}$.

\begin{tabular}{|c|c|c|c|}
\hline Name and Structure & Removal conditions & $\begin{array}{l}\text { Stability to the } \\
\text { removal of }\end{array}$ & Ref. \\
\hline Allyl (Al) & $\mathrm{Pd}\left(\mathrm{Ph}_{3}\right)_{4}$, scavengers & Boc, Fmoc, $Z^{\text {a }}$ & $\begin{array}{l}97, \\
163 \\
442\end{array}$ \\
\hline o-Nitrobenzyl (oNB): & Photolysis $(\lambda=350 \mathrm{~nm}), 12 \mathrm{~h}$ & Boc, Fmoc, Trt & $\begin{array}{l}443, \\
444\end{array}$ \\
\hline Propargyloxycarbonyl (Poc) & $\begin{array}{l}{\left[\left(\mathrm{PhCH}_{2} \mathrm{NEt}_{3}\right)_{2} \mathrm{MoS}_{4}\right] \text { in }} \\
\mathrm{AcCN}, 1 \mathrm{~h} .\end{array}$ & Boc, Trt & \\
\hline $\begin{array}{c}\text { Boc-N-methyl-N-[2- } \\
\text { (methylamino)ethyl]carbamoyl } \\
(\text { Boc-Nmec })\end{array}$ & $\begin{array}{l}\text { i) } 25-50 \% \text { TFA } \\
\text { ii) } N \text {-methylmorpholine (10 } \\
\text { eq) in } \mathrm{DMF} / \mathrm{H}_{2} \mathrm{O}(3: 7), 4 \mathrm{~h}\end{array}$ & Fmoc, Trt & \\
\hline
\end{tabular}

${ }^{a}$ Except catalytical hydrogenation removal. 


\section{TRYPTOPHAN (Trp)}

\subsection{General}

The indole group of Trp (Figure 30) can undergo oxidation and alkylation if it is not protected. ${ }^{446}$

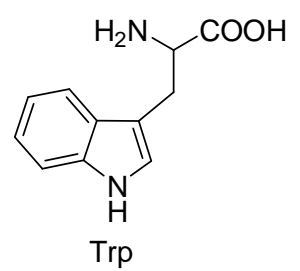

Figure 30. Tryptophan (Trp)

Alkylation during acid treatments can be done by carbocations from released protecting groups or from the resin, the latter leading to irreversible bonding of the peptide to the support (Figure 31). ${ }^{447}$
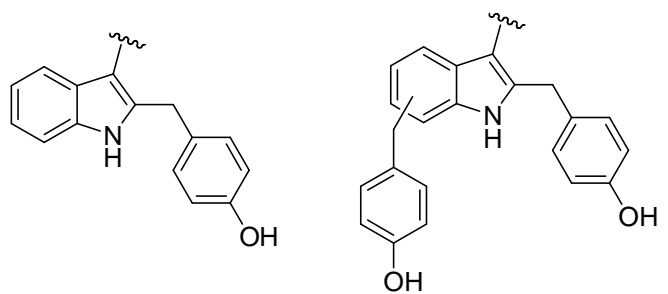

Figure 31. Alkylation of Trp by the Wang linker side products

Dimerization of Trp caused by alkylation by another protonated Trp has also been observed (Figure 32). ${ }^{448,449}$

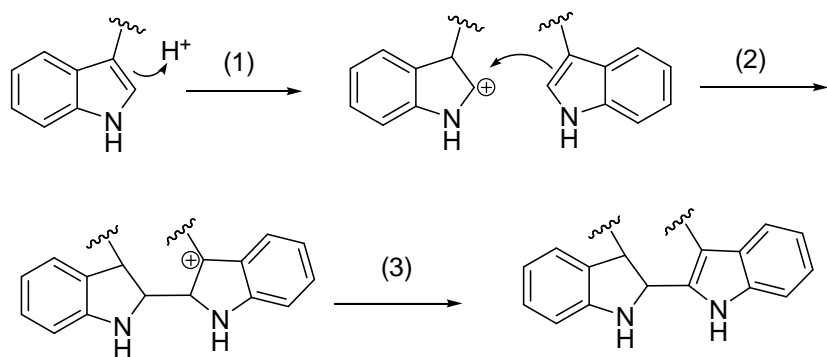

Figrue 32. Mechanism of Trp dimerization. (1) Protonation, (2) Nucleophilic attack (3) Elimination.

In the Boc/Bn strategy, the higher risk of oxidation and alkylation in acidic media makes the protection of Trp necessary. In addition, care must be taken when chosing the 
scavengers in the final cleavage. For instance, thioanisole should be avoided because thioanisole cation adducts can alkylate Trp, and TIS, which is mainly used in the Fmoc/t'Bu strategy, should be used instead of TES to prevent reduction of the indole ring of Trp to indoline. ${ }^{450}$ The most used protecting group for the Boc/Bn strategy is For (formyl).

In contrast, in the Fmoc/t'Bu strategy unprotected Trp is often used. However, in many cases protection is necessary. A critical example is when the peptidic sequences contain Arg protected by either Mtr, Pmc or Pbf groups, which after removal can react the indole ring in the 2 position. ${ }^{41,452}$ The most used protecting group for the $\mathrm{Fmoc} /{ }^{t} \mathrm{Bu}$ strategy is Boc.

\subsection{Introduction of the protecting groups}

Carbamate protection of the tert-butyl, benzyl, or phenacyl esters of $\mathrm{N}^{\alpha}$ Boc or Z-Trp is easily carried out using di-tert-butyl-dicarbonate or an appropiate chloroformate in the presence of a tertiaty base. After that, the carboxylic acid and/or amino-protecting groups are removed and $N^{\alpha}$ derivatization yields the Boc and Fmoc derivatives of the protected Trp. ${ }^{453,454,455,456,457}$ The formyl group is introduced using an excess of formic acid. $^{458}$

\subsection{Removal}

\subsubsection{Protecting groups removed by acid}

- Formyl (For). ${ }^{459}$ Removal with HF may be slow and the use of thiols (i.e. EDT) as scavengers makes it faster ${ }^{460}$ In the case of base cleavage, care must be taken with the reaction conditions in order to avoid free amine formylation. ${ }^{461,462}$

- tert-Butyloxycarbonyl (Boc). ${ }^{455,456} \mathrm{It}$ is removed with high concentrations of TFA and is the protecting group of choice for the Fmoc/ ${ }^{t} \mathrm{Bu}$ solid phase strategy. It is more stable than Boc $\alpha$-amino protection, which can be removed in the presence of protected $\operatorname{Trp}$ if care is taken with the reaction conditions, but not as a routine procedure. Boc protection avoids Trp alkylation during the removal of Mtr, Pmc and Pbf from the Arg sidechain. ${ }^{463,464}$ The $N$-carboxylated compound can be detected after tert-butyl removal but later becomes unstable thereby giving the free indole. The stability of this carbamic acid makes Boc-protected Trp less prone to electrophilic additions during the final cleavage. ${ }^{455,456}$

- Cyclohexyloxycarbonyl $(\mathrm{Hoc}){ }^{454}$ It is an alternative to the formyl group for the Boc/Bn strategy. Its high resistance to bases makes it useful for the synthesis of protected peptides on base-labile resins. ${ }^{465}$ Although it is generally removed with HF in 
the presence of $p$-cresol, Trp alkylation by $p$-cresol can occur during the removal. A proposed solution for this problem is the use of Fmoc-Leu or butanedithiol as scavengers. ${ }^{466}$

- Mesitylene-2-sulfonyl (Mts). ${ }^{467}$ Another alternative for the Boc/Bn strategy, Mts is removed by $1 \mathrm{M} \mathrm{CF}_{3} \mathrm{SO}_{3} \mathrm{H} / \mathrm{TFA}$ or $\mathrm{MeSO}_{3} \mathrm{H}$ but not by $\mathrm{HF}$. Although it has not been widely applied, there are reports of its use. ${ }^{468}$

\begin{tabular}{|c|c|c|c|}
\hline Name and Structure & Removal conditions & $\begin{array}{l}\text { Stability to the } \\
\text { removal of }\end{array}$ & Ref. \\
\hline Formyl (For) & $\begin{array}{l}\text { 1) Strong acid (HF) } \\
\text { and scavengers (i.e. } \\
\text { EDT) (slow) } \\
\text { 2) piperidine- } \mathrm{H}_{2} \mathrm{O} \text { or } \\
\text { DMF } \\
\text { 3) } 1 \mathrm{M} \mathrm{NH}_{2} \mathrm{OH}, \mathrm{pH} 9 \text {, } \\
\text { 2h }\end{array}$ & Boc & $\begin{array}{l}459, \\
460, \\
461, \\
462\end{array}$ \\
\hline tert-Butyloxycarbonyl (Boc) & $\begin{array}{l}\text { 95\% TFA and } \\
\text { scavengers }{ }^{\text {a }}\end{array}$ & Fmoc, Alloc & $\begin{array}{l}455, \\
456, \\
463, \\
464\end{array}$ \\
\hline Cyclohexyloxycarbonyl (Hoc) & HF, scavengers & $\begin{array}{l}\text { Boc, Fmoc, } \\
\text { Alloc, }\end{array}$ & $\begin{array}{l}454, \\
465 \\
466\end{array}$ \\
\hline Mesitylene-2-sulfonyl (Mts) & $\begin{array}{l}\text { 1) } \mathrm{CF}_{3} \mathrm{SO}_{3} \mathrm{H} / \mathrm{TFA} \\
\text { 2) } \mathrm{MeSO}_{3} \mathrm{H}\end{array}$ & $\begin{array}{l}\text { Boc, Fmoc, } \\
\text { Alloc, }\end{array}$ & $\begin{array}{l}467, \\
468\end{array}$ \\
\hline
\end{tabular}

${ }^{\mathrm{a}}$ The carbamic acid resulting from tert-butyl removal is quite stable. Complete decarboxylation takes place by treatment with $0.1 \mathrm{M} \mathrm{AcOH}_{(\mathrm{aq})}$ or more slowly during lyophilization in $\mathrm{H}_{2} \mathrm{O}$.

\subsubsection{Protecting groups removed by base}

- Formyl (For): see protecting groups removed by acid. 


\subsubsection{Other protecting groups}

- Allyloxycarbonyl (Alloc). ${ }^{457}$ Removed with Pd (0), its orthogonality to Boc and Fmoc (when removed with DBU but not when removed with piperidine) makes it potentially useful for both the Boc/Bn and the Fmoc ${ }^{t} \mathrm{Bu}$ solid phase strategies.

\begin{tabular}{|l|l|l|l|}
\hline Name and Structure & Removal conditions & $\begin{array}{l}\text { Stability to the } \\
\text { removal of }\end{array}$ & Ref. \\
\hline Allyloxycarbonyl (Alloc) & $\begin{array}{l}\mathrm{Pd}\left(\mathrm{PPh}_{3}\right)_{4}, \\
\text { methylanylin in } \\
\text { DMSO-THF- } 0.5 \mathrm{M} \\
\mathrm{HCl}(1: 1: 0.5), 8 \mathrm{~h}\end{array}$ & $\mathrm{Boc}$ & 457 \\
& & & \\
\hline
\end{tabular}

\section{ABBREVIATIONS}

$\mathrm{AB}$ linker 3-(4-Hydroxymethylphenoxy)propionic acid linker

$\mathrm{Acm}$ Acetamidomethyl

AcOH Acetic acid

1-Ada 1-Adamantyl

Al Allyl

Alloc Allyloxycarbonyl

API Active Pharmaceutical Ingredients

Arg Arginine

Asn Asparagine

Asp Aspartic acid

Azoc Azidomethyloxycarbonyl

Bn Benzyl

BAL Backbone Amide Linker

Boc tert-Butyloxycarbonyl

Bom Benzyloxymethyl

Bpoc 2-(4-Biphenyl)isopropoxycarbonyl

BrBn 2-Bromobenzyl

$\mathrm{BrPhF}$ 9-(4-Bromophenyl)-9-fluorenyl

BrZ 2-Bromobenzyloxycarbonyl

Bsmoc 1,1-Dioxobenzo[b]thiophene-2-ylmethyloxycarbonyl

Bum tert-Butoxymethyl

Cam Carboxamidomethyl

cHx Cyclohexyl

Cl-Z 2-Chlorobenzyloxycarbonyl

Cpd Cyclopropyldimethylcarbinyl

Cys Cysteine

Dab Diaminobutyric acid

Dap Diaminopropionic acid

DBU 1,8-Diazabicyclo[5.4.0]undec-7-ene

Dcb 2,6-Dichlorobenzyl

DCHA Dicyclohexylammonium

DCM Dichloromethane 


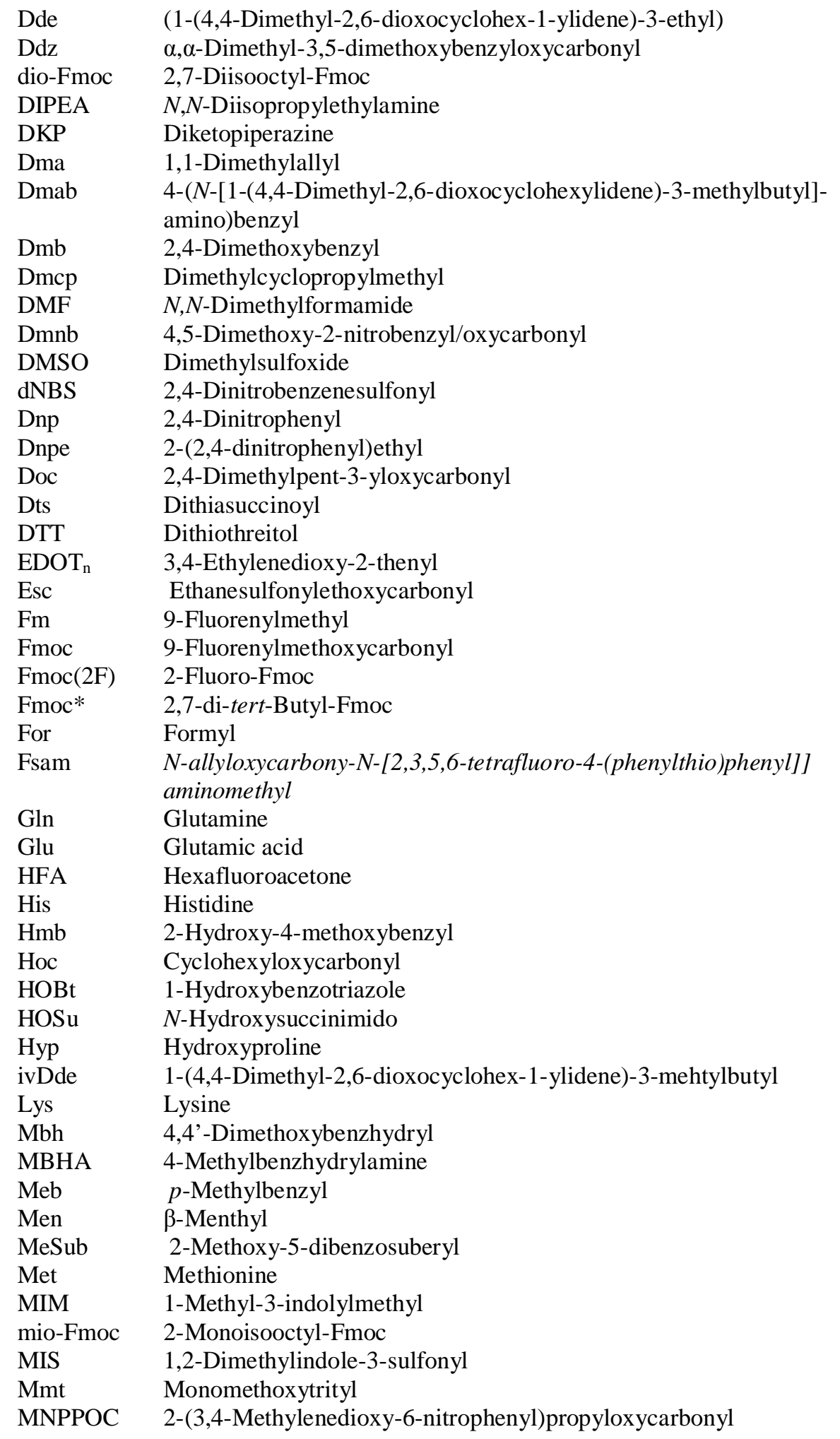




\begin{tabular}{|c|c|}
\hline Mob & $p$-Methoxybenzyl \\
\hline Mpe & $\beta$-3-Methylpent-3-yl \\
\hline Msc & 2-(Methylsulfonyl)ethoxycarbonyl \\
\hline Mtr & 4-Methoxy-2,3,6-trimethylphenylsulfonyl \\
\hline Mts & Mesitylene-2-sulfonyl \\
\hline Mtt & 4-Methyltrityl \\
\hline $\mathrm{NCA}$ & $N$-carboxy anhydrides \\
\hline Nin & Ninhydrin \\
\hline NMM & $N$-methyl mercaptoacetamide \\
\hline NMP & 1-Methylpyrrolidin-2-one \\
\hline NPPOC & 2-(2-Nitrophenyl)propyloxycarbonyl \\
\hline Nps & 2-Nitrophenylsulfanyl \\
\hline Npys & 3-Nitro-2-pyridinesulfenyl \\
\hline Nsc & 2-(4-Nitrophenylsulfonyl)ethoxycarbonyl \\
\hline$\alpha-N s m o c$ & 1,1-Dioxonaphtho[1,2-b]thiophene-2-methyloxycarbonyl \\
\hline NVOC & 6-Nitroveratryloxycarbonyl \\
\hline oNBS & $o$-Nitrobenzenesulfonyl \\
\hline oNZ & $o$-Nitrobenzyloxycarbonyl \\
\hline Orn & Ornithine \\
\hline Pac & Phenacyl \\
\hline $\mathrm{Pbf}$ & Pentamethyl-2,3-dihydrobenzofuran-5-sulfonyl \\
\hline Pen & 3-Pentyl \\
\hline $\mathrm{PhAcm}$ & Phenylacetamidomethyl \\
\hline Phdec & Phenyldithioethyloxycarbonyl \\
\hline 2-Phi $\mathrm{Pr}$ & 2-Phenylisopropyl \\
\hline $\mathrm{pHP}$ & $p$-Hydroxyphenacyl \\
\hline Pmbf & 2,2,4,6,7-Pentamethyl-5-dihydrobenzofuranylmethyl \\
\hline Pmc & 2,2,5,7,8-Pentamethylchroman-6-sulfonyl \\
\hline Pms & 2-[Phenyl(methyl)sulfonio]ethyloxycarbonyl tetrafluoroborate \\
\hline PNA & Peptide Nucleic Acid \\
\hline $\mathrm{pNB}$ & $p$-Nitrobenzyl \\
\hline pNBS & $p$-Nitrobenzenesulfonyl \\
\hline pNZ & $p$-Nitrobenzyloxycarbonyl \\
\hline Poc & Propargyloxycarbonyl \\
\hline$\Psi$ Pro & Pseudoprolines \\
\hline Pydec & 2-Pyridyldithioethyloxycarbonyl \\
\hline Ser & Serine \\
\hline SPPS & Solid Phase Peptide Synthesis \\
\hline Sps & 2-(4-Sulfophenylsulfonyl)ethoxycarbonyl \\
\hline SPS & Solid Phase Synthesis \\
\hline S-Pyr & 2-Pyridinesulfenyl \\
\hline $\mathrm{S}^{\mathrm{t}} \mathrm{Bu}$ & tert-Butylmercapto \\
\hline Sub & 5-Dibenzosuberyl \\
\hline Suben & $\omega$-5-Dibenzosuberenyl \\
\hline TAEA & tris(2-Aminoethyl)amine \\
\hline TBAF & Tetrabuthylammonium fluoride \\
\hline TBDMS & tert-Butyldimethylsilyl \\
\hline TBDPS & tert-Butyldiphenylsilyl \\
\hline${ }^{t} \mathrm{Bu}$ & tert-Butyl \\
\hline TCA & Trichloroacetic acid \\
\hline
\end{tabular}




$\begin{array}{ll}\text { Tce } & \text { 2,2,2-Trichloroethyl } \\ \text { TCEP } & \text { tris-Carboxymethylphosphine } \\ \text { TCP } & \text { Tetrachlorophthaloyl } \\ \text { TEA } & \text { Triethylamine } \\ \text { TEAF } & \text { Tetraethylammonium fluoride } \\ \text { TFA } & \text { Trifluoroacetic acid } \\ \text { tfa } & \text { Trifluoroacetyl } \\ \text { TFE } & \text { 2,2,2-Trifluoroethanol } \\ \text { TFMSA } & \text { Trifluoromethanesulfonic acid } \\ \text { Thr } & \text { Threonine } \\ \text { Tmob } & \text { 2,4,6-Trimethoxybenzyl } \\ \text { TMS } & \text { Trimethylsilyl } \\ \text { TMSE } & \text { Trimethylsilylethyl } \\ \text { Tmsi } & \text { 2-(Trimethylsilyl)isopropyl } \\ \text { Tos } & \text { Tosyl } \\ \text { Troc } & \text { 2,2,2-Trichloroethyloxycarbonyl } \\ \text { Trp } & \text { Tryptophan } \\ \text { Trt } & \text { Trityl } \\ \text { Tyr } & \text { Tyrosine } \\ \text { Xan } & \text { 9-Xanthenyl } \\ \text { Z } & \text { Benzyloxycarbonyl }\end{array}$

\section{REFERENCES}

(1) Green, T. W.; Wuts, P. G. M. Protective Groups in Organic Synthesis. Ed. John Wiley and Sons: New York, 1999.

(2) Kocienski, P. J. Protecting Groups. Ed. Georg Thieme Verlag: Stuttgart-New York, 2004.

(3) Fischer, E.; Bergmann, M.. Ber. Deut. Chem. Ges. 1918, 51, 1760.

(4) Bergmann, M.; Zervas, L. Ber. Deut. Chem. Ges. 1932, 65B, 1192.

(5) Barany G.; Merrifield R. B. J. Am. Chem. Soc. 1977, 99, 7363.

(6) Barany, G.; Albericio, F. J. Am. Chem. Soc. 1985, 107, 4936.

(7) Fmoc protection: Chang, C.-D.; Waki, M.; Ahmad, M.; Meienhofer, J.; Lundell, E. O.; Haug, J. D. Int. J. Pept. Prot. Res. 1980, 15, 59.

(8) Z protection: Sennyey, G.; Barcelo, G.; Senet, J. P. Tetrahedron Lett. 1986, 27, 5375 .

(9) Boc protection: Keller, O.; Keller, W. E.; Van Look, G.; Wersin, G. Org. Synth. 1985, 63, 160 .

(10) Trt protection via intermediate trityl esters: Mutter, M.; Hersperger, R. Synthesis 1989, 3, 198. 
(11) Tessier, M.; Albericio, F. ; Pedroso, E.; Grandas, A.; Eritja, R.; Giralt, E. ; Granier, C.; van Rietschoten, J. Int. J. Pept. Protein Res. 1983, 22, 125.

(12) Sigler, G. F.; Fuller, W. D.; Chaturvedi, N. C.; Goodman, M.; Verlander, M. Biopolymers 1983, 22, 2157.

(13) Lapatsanis, L., Milias, G., Froussios, K.; Kolovos, M. Synthesis 1983, 671.

(14) Ten Kortenaar, P. B. W.; Van Dijk, B. G.; Peeters, J. M.; Raaben, B. J.; Adams, P. J.; Hans, M.Tesser, G. I. Int. J. Pept. Protein Res. 1986, 27, 398.

(15) Paquet, A. Can. J. Chem. 1982, 60, 976.

(16) Milton, R. C.; Becker, E.; Milton, S. C.; Baxter, J. E. J.; Elsworth, J. F. Int. J. Pept. Prot. Res. 1987, 30, 431.

(17) Fmoc-N3: Cruz, L. J.; Beteta, N. G.; Ewenson, A.; Albericio, F. Org. Proc. Res. Dev. 2004, 8, 920.

(18) Bolin, D. R.; Sytwu, I. I.; Humiec, F.; Meienhofer, J. Int. J. Pept. Prot. Res. 1989, 33,353 .

(19) Isidro-Llobet, A.; Just-Baringo, X.; Ewenson, A.; Álvarez, M.; Albericio, F. Biopolymers 2007, 88, 733.

(20) Barlos, K.; Papaioannou, D.; Theodoropoulos, D. J. Org. Chem. 1982, 47, 1324.

(21) Hlebowicz, E.; Andersen, A.J.; Andersson, L.; Moss, B.A. J. Pept. Res. 2005, 65, 90-

(22) Carpino, L. A. J. Am. Chem. Soc. 1957, 79, 4427.

(23) Anderson, G.W.; Alberston, N.F. J. Am. Chem. Soc. 1957, 79, 6180.

(24)Merrifield, R. B. J. Am. Chem. Soc. 1963, 85, 2149.

(25) Merrifield, R. B. Adv. Enzymol. 1969, 32, 221.

(26) Kaiser, E.; Picart, F.; Kubiak, T.; Tam, J. P.; Merrifield, R. B. J. Org. Chem. 1993, $58,5167$.

(27) Stewart, J. M.; Young, J. D. Solid Phase Peptide Synthesis. 2nd ed., Pierce Chemical Company: Rockford, IL, 1984.

(28) Barlos, K.; Mamos, P.; Papaioannou, D.; Patrianakou, S.; Sanida, C.; Schaefer, W. Liebigs Ann. Chem. 1987, 12, 1025.

(29) Bodanszky M.; Bednarek M. A.; Bodanszky A. Int. J. Pept. Prot. Res. 1982, 20, 387.

(30) Alsina, J.; Giralt, E.; Albericio, F. Tetrahedron Lett. 1996, 37, 4195. 
(31) de la Torre, B. G.; Marcos, M. A.; Eritja, R.; Albericio, F. Solid-phase peptide synthesis using $N$ - $\alpha$-tritylamino acids. Lett. Pepide Sci. 2001, 8, 331.

(32)Floersheimer, A.; Riniker, B. Peptides 1990: Proc. 21 st European Peptide Symposium, Giralt, E.; Andreu, D. eds., ESCOM Sci. Publ.: Leiden, 1990, 131.

(33) 2,5-Diketopiperazines can be formed after the removal of the $\alpha$-amino group from the second $C$-terminal amino acid due to nucleophilic attack of the free amine to the carboxylate group of the $C$-terminal amino acid.

(34) Gairí, M.; Lloyd-Williams, P.; Albericio, F.; Giralt, E. Tetrahedron Lett. 1990, 31, 7363.

(35) Barlos, K.; Papaioannou, D.; Patrianakou, S.; Tsegenidis, T. Liebigs Ann. Chem. 1986, $11,1950$.

(36) Birr, C.; Lochinger, W.; Stahnke, G.; Lang, P.. Liebigs Ann. Chem. 1972, 763, 162.

(37) Birr, C. In Innovation and Perspectives in Solid Phase Synthesis; Epton, R., Ed.; SPCC (UK) Ltd.: Birmingham, UK, 1990, 155-181.

(38) Jensen, K.J.; Alsina, J.; Songster, M.F.; Vágner, J.; Albericio, F.; Barany, G. J. Am. Chem. Soc. 1998, 120, 5441.

(39) Wang, S. S.; Yang, C. C.; Kulesha, I. D.; Sonenberg, M.; Merrifield, R. B. Int. J. Pept. Prot. Res. 1974, 6, 103.

(40) Mojsov S; Merrifield R.B. Biochemistry 1981, 20, 2950.

(41) Albericio, F. Biopolymers 2000, 55, 123.

(42) Carey, R. I.; Bordas, L. W.; Slaughter, R. A.; Meadows, B. C.; Wadsworth, J. L.; Huang, H.; Smith, J. J.; Furusjo, E. J. Pept. Res. 1997, 49, 570.

(43) Attard, T. J.; Reynolds, E. C.; Perich, J. W. Org. Biomol. Chem. 2007, 5, 664670.

(44) Zaramella, S.; Yeheskiely, E.; Stroemberg, R. J. Am. Chem. Soc. 2004, 126, 14029.

(45) Zervas, L.; Borovas, D.; Gazis, E. J. Am. Chem. Soc. 1963, 85, 3660.

(46) Najjar, V. A.; Merrifield, R. B. Biochemistry 1966, 5, 3765.

(47) Tun-Kyi, A. Helv. Chim. Acta. 1978, 61, 1086.

(48) Meienhofer, J. Nature 1965, 205, 73.

(49) Carpino, L. A.; Han, G. Y. J. Am. Chem. Soc. 1970, 92, 5748.

(50) Carpino, L. A.; Han, G. Y. J. Org. Chem. 1972, 37, 3404. 
(51) Rabanal, F.; Haro, I.; Reig, F.; García-Antón, J. M. An. Quim. 1990, 86, 84.

(52) Butwell, F. G. W.; Haws, E. J.; Epton, R. Makromol. Chem., Macromol. Symp. 1988, 19, 69.

(53) Carpino, L. A.; Mansour, E. M. E.; Cheng, C. H.; Williams, J. R.; MacDonald, R.; Knapczyk, J.; Carman, M.; Lopusinski, A. J. Org. Chem. 1983, 48, 661.

(54) Carpino, L. A.; Mansour, E. M. E.; Knapczyk, J. J. Org. Chem. 1983, 48, 666.

(55) Atherton, E.; Fox, H; Harkiss, D.; Logan, C. J.; Sheppard, R. C.; Williams, B. J. J. Chem. Soc., Chem. Commun. 1978, 13, 537.

(56) Chang, C.-D.; Meienhofer, J. Int. J. Pept. Prot. Res. 1978, 11, 246-249.

(57) Wade, J. D.; Bedford, J.; Sheppard, R. C.; Tregear, G. W. Pept. Res. 1991, 4, 194.

(58) Meldal, M.; Bielfeldt, T.; Peters, S.; Jensen, K. J.; Paulsen, H.; Bock, K. Int. J. Pept. Prot. Res. 1994, 43, 529.

(59) Liebe, B.; Kunz, H. Angew. Chem. Int. Ed. in Eng. 1997, 36, 618.

(60) Li, X.; Kawakami, T.; Aimoto, S. Tetrahedron Lett. 1998, 39, 8669.

(61) Martinez, J.; Bodanszky, M. Int. J. Petide Protein Res., 1978, 12, 277.

(62) Doelling, R.; Beyermann, M.; Haenel, J.; Kernchen, F.; Krause, E.; Franke, P.; Brudel, M.; Bienert, M. J. Chem. Soc., Chem. Commun. 1994, 853.

(63) Han, Y.-K.; Johnston, D. A.; Khatri, H. N. PCT Int. Appl. WO 2006069727 A2, 2006, Chem. Abstr. 2006, 145, 103960.

(64) Samukov, V. V.; Sabirov, A.; Pozdnyakov, P. I. Tetrahedron Lett. 1994, 35, 7821.

(65) Sabirov, A. N.; Kim, Y.-D.; Kim, H.-J.; Samukov, V. V. Protein Peptide Lett. 1997, 4, 307.

(66) Ramage, R.; Jiang, L.; Kim, Y.-D.; Shaw, K.; Park, J.-L.; Kim, H.-J. J. Pept. Sci. 1999, 5, 195.

(67) Carreño, C.; Mendez, M. E.; Kim, Y.-D.; Kim, H.-J.; Kates, S. A.; Andreu, D.; Albericio, F. J. Pept. Res. 2000, 56, 63.

(68) Maier, T. C.; Podlech, J. Adv. Synth. Cat. 2004, 346, 727-.

(69) Lauer, J. L.; Fields, C. G.; Fields, G. B. Lett. Pept. Sci. 1995, 1, 197.

(70) Carpino, L. A.; Philbin, M.; Ismail, M.; Truran, G. A.; Mansour, E. M. E.; Iguchi, S.; Ionescu, D.; El-Faham, A.; Riemer, C.; Warrass, R.; Weiss, M. S. J. Am. Chem. Soc. 1997, 119, 9915.

(71) Carpino, L. A.; Philbin, M. J. Org. Chem. 1999, 64, 4315.

(72) Carpino, L. A.; Mansour, E. M. E. J. Org. Chem. 1999, 64, 8399. 
(73) Carpino, L. A.; Ismail, M.; Truran, G. A.; Mansour, E. M. E.; Iguchi, S.; Ionescu, D.; El-Faham, A.; Riemer, C.; Warrass, R. J. Org. Chem. 1999, 64, 4324.

(74) Carpino, L. A.; Ghassemi, S.; Ionescu, D.; Ismail, M.; Sadat-AAlaee, D.; Truran, G. A.; Mansour, E. M. E.; Siwruk, G. A.; Eynon, J. S.; Morgan, B. Org. Process Res. Dev. 2003, 7, 28.

(75) Carpino, L. A.; Abdel-Maksoud, A. A.; Ionescu, D.; Mansour, E. M. E.; Zewail, M. A. J. Org. Chem. 2007, 72, 1729.

(76)Hillman, Jeffrey D.; Orugunty, Ravi S.; Smith, James L. Preparation of orthogonally-protected lanthionines for the synthesis of Nisin A analog and other intramolecularly bridged polypeptides. U.S. Pat. Appl. Publ. (2007), 23pp. CODEN: USXXCO US 2007037963 A1 20070215 CAN 146:252110 AN 2007:175279 CAPLUS

(77) Stigers, K. D.; Koutroulis, M. R.; Chung, D. M.; Nowick, J. S. J. Org. Chem. 2000, 65, 3858.

(78) Chinchilla, R.; Dodsworth, D. J.; Najera, C.; Soriano, J. M. Bioorg. Med. Chem. Lett. 2002, 12, 1817.

(79) Woods, R. J.; Brower, J. O.; Castellanos, E.; Hashemzadeh, M.; Khakshoor, O.; Russu, W. A.; Nowick, J. S. J. Am. Chem. Soc. 2007, 129, 2548.

(80) Hasegawa, K.; Sha, Y. L.; Bang, J. K.; Kawakami, T.; Akaji, K.; Aimoto, S. Lett. Pept. Sci. 2002, 8, 277.

(81) Wessig, P.; Czapla, S.; Moellnitz, K.; Schwarz, J. Synlett 2006, 14, 2235.

(82) Cros, E.; Planas, M.; Barany, G.; Bardaji, E.. Eur. J. Org. Chem. 2004, 17, 3633.

(83) Hojo, K.; Maeda, M.; Kawasaki, K. J. Pept. Sci. 2001, 7, 615.

(84) Hojo, K.; Maeda, M.; Kawasaki, K. Tetrahedron 2004, 60, 1875.

(85) Hojo, K.; Maeda, M.; Smith, T. J.; Kita, E.; Yamaguchi, F.; Yamamoto, S.; Kawasaki, K. Chem. Pharm. Bull. 2004, 52, 422.

(86) Hojo, K.; Maeda, M.; Kawasaki, K. Tetrahedron Lett. 2004, 45, 9293.

(87) Ben-Ishai, D.; Berger, A. J. Org. Chem. 1952, 17, 1564.

(88) Mitchell, A. R.; Merrifield, R. B. J. Org. Chem. 1976, 41, 2015.

(89) Kiso, Y.; Ukawa, K.; Akita, T. J. Chem. Soc. Chem. Commun. 1980, 3, 101.

(90) Sakakibara, S.; Shimonishi, Y.; Kishida, Y.; Okada, M.; Sugihara, H. Bull. Chem. Soc. Jap. 1967, 40, 2164.

(91) Felix, A. M. J. Org. Chem. 1974, 39, 1427.

(92) Podlech, J.; Gurrath, M.; Müller, G.; Lohof, E. Protection of the $\alpha$-Amino Group. In "Synthesis of Peptides and Peptidomimetics (Houben-Weyl E22a: Methods of 
Organic Chemistry)", Goodman, M.; Felix, A.M.; Moroder, L.; Toniolo, C. eds., Georg Thieme Verlag: Stuttgart and New York, 2002, pp. 41-165.

(93) Stevens, C. M.; Watanabe, R. J. Am. Chem. Soc. 1950, 72, 725.

(94) Tsuji, J. Tetrahedron 1986, 42, 4361, and references cited therein.

(95) Trost, B. M.; van Vranken, D. L. Chem. Rev. 1996, 96, 395, and references cited therein.

(96) Guibé, F. Tetrahedron 1997, 53, 13509.

(97) Guibé, F. Tetrahedron 1998, 54, 2967.

$98 \mathrm{Me}_{2} \mathrm{NH} \cdot \mathrm{BH}_{3}$ proved to be more efficient than $\mathrm{PhSiH}_{3}$ for Alloc deprotection of secondary amines: Fernandez-Forner, D.; Casals, G.; Navarro, E.; Ryder, H.; Albericio, F. Tetrahedron Lett. 2001, 42, 4471.

(99) Dessolin, M,; Guillerez, M.-G.; Thieriet, N.; Guibé, F.; Loffet, A. Tetrahedron Lett. 1995, 36, 5741.

(100) Gómez-Martínez, P.; Dessolin, M.; Guibé, F. Albericio, F. J. Chem. Soc. Perk. 1. 1999, 22871. .

(101) Thieriet, N.; Gomez-Martinez, P.; Guibé, F. Tetrahedron Lett. 1999, 40, 2505.

(102) Thieriet, N.; Alsina, J..; Giralt, E.; Guibé, F.; Albericio, F. Tetrahedron Lett. 1997, 38, 7275 .

(103) Gracia, C.; Isidro-Llobet, A.; Cruz, L. J.; Acosta, G. A.; Álvarez, M.; Cuevas, C.; Giralt, E.; Albericio, F. J. Org. Chem. 2006, 71, 7196.

(104) Fukuyama, T.; Jow, C.-K.; Cheung, M. Tetrahedron Lett. 1995, 36, 6373.

(105) Vedejs, E.; Lin, S.; Klapars, A.; Wang, J. J. Am. Chem. Soc. 1996, 118, 9796.

(106) Miller, S. C.; Scanlan, T. S. J. Am. Chem. Soc. 1997, 119, 2301.

(107) Biron, E.; Kessler, H. J. Org. Chem. 2005, 70, 5183.

(108) Fukuyama, T.; Cheung, M.; Jow, C.-K.; Hidai, Y.; Kan, T. Tetrahedron Lett. 1997, 38, 5831.

(109) Vedejs, E.; Kongkittingam, C. J. Org. Chem. 2000, 65, 2309.

(110) Marsault, E.; Benakli, K.; Beaubien, S.; Saint-Louis, C.; Deziel, R.; Fraser, G. Bioorg. Med. Chem. Lett. 2007, 17, 4187.

(111) Marsault, E.; Hoveyda, H. R.; Peterson, M. L.; Saint-Louis, C.; Landry, A.; Vezina, M.; Ouellet, L.; Wang, Z.; Ramaseshan, M.; Beaubien, S.; Benakli, K.; Beauchemin, S.; Deziel, R.; Peeters, T.; Fraser, G. L. J. Med. Chem. 2006, 49, 7190. 
(112) Woodward, R.B.; Heusler, K.; Gosteli, J.; Naegeli, P.; Oppolzer, W.; Ramage, R.; Ranganathan, S.; Vorbrüggen, H. J. Am Chem. Soc. 1966, 88, 852.

(113) Carson, J. F. Synthesis 1981, 268.

(114) Barany, G.; Merrifield, R. B. J. Am. Chem. Soc. 1980, 102, 3084.

(115) Albericio, F.; Barany, G. Int. J. Pept. Prot. Res. 1987, 30, 177.

(116) Planas, M.; Bardají, E.; Jensen, K. J.; Barany, G. J. Org. Chem. 1999, 64, 7281.

(117) Jensen, K. J.; Hansen, P. R.; Venugopal, D.; Barany, G. J. Am. Chem. Soc. 1996, 118,3148 .

(118) Carpenter, F. H.; Gish, D. T. J. Am. Chem. Soc. 1952, 74, 3818.

(119) Isidro-Llobet, A.; Guasch-Camell, J.; Álvarez, M.; Albericio, F. Eur. J. Org. Chem. 2005, 3031.

(120) Liao, W.; Piskorz, C. F.; Locke, R. D.; Matta, K. L. Bioorg. Med. Chem. Lett. 2000, 10, 793.

(121) Tulla-Puche, J.; Bayó-Puxan, N.; Moreno, J. A.; Francesch, A. M.; Cuevas, C.; Álvarez, M.; Albericio, F. J. Am. Chem. Soc. 2007, 129; 5322.

(122) Meldal, M.; Juliano, M. A.; Jansson, A. M. Tetrahedron Lett. 1997, 38, 2531.

(123) Tornoe, C. W.; Davis, P.; Porreca, F.; Meldal, M. J. Pept. Sci. 2000, 6, 594.

(124) Lundquist, J. T., IV; Pelletier, J. C. Org. Lett. 2001, 3, 781.

(125) Lundquist, J. T.; Pelletier, J. C. Org. Lett. 2002, 4, 3219.

(126) Bhat, R. G.; Sinha, S.; Chandrasekaran, S. Chem. Commun. 2002, 8, 812.

(127) Sinha, S.; Ilankumaran, P.; Chandrasekaran, S. Tetrahedron Lett. 1999, 40, 771.

(128) Patchornik, A.; Amit, B.; Woodward, R. B. J. Am. Chem. Soc. 1970, 92, 6333.

(129) Fodor, S. P. A.; Read, J. L.; Pirrung, M. C.; Stryer, L.; Lu, A. T.; Solas, D. Science 1991, 251, 767.

(130) Bhushan, K. R.; DeLisi, C.; Laursen, R. A. Tetrahedron Lett. 2003, 44, 8585.

(131) Bhushan, K. R. Abstracts of Papers, 232nd ACS National Meeting, 2006.

(132) Surprenant, S.; Lubell, W. D. J. Org. Chem. 2006, 71, 848.

(133) Kaul, R.; Brouillette, Y.; Sajjadi, Z.; Hansford, K. A.; Lubell, W. D. J. Org. Chem. 2004, 69, 6131.

(134) Pothukanuri, S.; Winssinger, N. Org. Lett. 2007, 9, 2223.

(135) Spengler, J.; Bröttcher, C.; Albericio, F.; Burger, K. Chem. Rev. 2006, 106, 4728.

(136) Farrera-Sinfreu, J.; Royo, M.; Albericio, F. Tetrahedron Lett. 2002, 43, 7813.

(137) Vig, B. S.; Murray, T. F.; Aldrich, J. V. Biopolymers 2003, 71, 620. 
(138) Kurtz, A. C. J. Biol. Chem. 1938, 122, 477.

(139) Wünsch, E. In „XV/1. Synthesis of Peptides, Protecting Groups I (Houben-Weyl: VII. The Synthesis of Peptides”, Wünsch, E. ed., Georg Thieme Verlag: Stuttgart, p 468.

(140) Wiejak, S.; Masiukiewicz, E.; Rzeskotarska, B. Chem. Pharm. Bull. 1999, 47, 1489.

(141) Albericio, F.; Nicolás, E.; Rizo, J.; Ruiz-Gayo, E.; Pedroso, E.; Giralt, E. Synthesis. 1990, 119.

(142) Bergmann, M.; Zervas, L.; Ross, W.F. J. Biol. Chem. 1935, 111, 245.

(143) Erickson, B.W.; Merrifield, R.B.; J. Am. Chem. Soc. 1973, 95, 3757.

(144) Schwyzer, R.; Rittel, W. Helv. Chim. Acta. 1961, 44, 159.

(145) Aletras, A.; Barlos, K.; Gatos, D.; Koutsogianni, S.; Mamos, P. Int. J. Pept. Prot. Res. 1995, 45, 488.

(146) Matysiak, S.; Böldicke, T.; Tegge, W.; Frank, R. Tetrahedron Lett. 1998, 39, 1733.

(147) Chhabra, S. R.; Hothi, B.; Evans, D. J.; White, P. D.; Bycroft, B. W.; Chan, W. C. Tetrahedron Lett. 1998, 39, 1603.

(148) Wittmann, V.; Seeberger, S. Angew. Chem. Int. Ed. Engl. 2000, 39, 4348.

(149) Bycroft, B, W.; Chan, W. C.; Chhabra, S. R.; Hone, N. D. J. Chem. Soc. Chem. Commun. 1993, 9, 778.

(150) Bloomberg, G. B.; Askin, D.; Gargaro, A. R.; Tanner, M. J. A. Tetrahedron Lett. 1993, 34, 4709 .

(151) Dumy, P.; Eggleston, I. M.; Cervigni, S.; Sila, U.; Sun, X.; Mutter, M. Tetrahedron Lett. 1995, 36, 1255.

(152) Rohwedder, B.; Mutti, Y.; Dumy, P.; Mutter, M. Tetrahedron Lett. 1998, 39, 1175.

(153) Schallenberg, E. E.; Calvin, M.; J. Am. Chem. Soc. 1955, 77, 2779.

(154) Weygand, F.; Csendes, E.; Angew. Chem. 1952, 64, 136.

(155) Goldberger, R.F.; Anfinsen, C.B. Biochemistry 1962, 1, 401.

(156) Ohno, M.; Eastlake, A.; Ontjes, D.; Anfinsen, C.B. J. Am. Chem. Soc. 1969, 91, 6842.

(157) Moroder, L.; Filippi, B.; Borin, G.; Marchiori, F. Biopolymers 1975, 14, 2061.

(158) Weygand, F.; Frauendorfer, E. Chem. Ber. 1970, 103, 2437. 
(159) Tesser, G. I.; Balvert-Geers, I.C. Int. J. Pept. Protein Res. 1975, 7, 295-305.

(160) Podlech, J.; Musiol, H-J.; Lohof, E.; Moroder, L. Protection of the $\omega$-Amino Group. In "Synthesis of Peptides and Peptidomimetics (Houben-Weyl E22a: Methods of Organic Chemistry)", Goodman, M.; Felix, A.M.; Moroder, L.; Toniolo, C. eds., Georg Thieme Verlag: Stuttgart and New York, 2002, pp. 166-192.

(161) Boon, P.J.; Mous, J.F.M.; ten Kortenaar, P.B.; Tesser, G. Int. J. Pept. Protein Res. 1986, 28, 477.

(162) Monroc, S.; Feliu, L.; Serra, J.; Planas, M.; Bardaji, E. Synlett 2006, 17, $2743-$.

(163) Loffet, A.; Zhang, H.X. Int. J. Pept. Prot. Res. 1993, 42, 346.

(164) Lyttle, M. H.; Hudson, D. Peptides Chemistry and Biology. Proceedings of the 12th American Peptide Symposium. Smith, J. A.; Rivier, J. E. Eds. ESCOM: Leiden, 1992, 583-584.

(165) Isidro-Llobet, A.; Álvarez, M.; Albericio, F. Terahedron. Lett. 2005, 46, 7733.

(166) López, P. E.; Isidro-Llobet, A.; Gracia, C.; Cruz, L. J.; García-Granados, A.; Parra, A.; Álvarez, M.; Albericio, F. Tetrahedron. Lett. 2005, 46, 7737.

(167) Rusiecki, V. K.; Warne, S. A. Bioorg. Med. Chem. Lett. 1993, 3, 707.

(168) Lapeyre, M.; Leprince, J.; Massonneau, M.; Oulyadi, H.; Renard, P-Y.; Romieu, A.; Trucatti, G.; Vaudry, H. Chem. Eur. J. 2006, 12, 3655.

(169) De Luca, S.; Della Moglie, R.; De Capua, A.; Morelli, G. Tetrahedron Lett. 2005, 46, 6637.

(170) Poreddy, A. R.; Schall, O. F.; Marshall, G. R.; Ratledge, C.; Slomczynska, U. Bioorg. Med. Chem. Lett. 2003, 13, 2553.

(171) Thieriet, N.; Guibé, F.; Albericio, F. Org. Lett. 2000, 2, 1815.

(172) Visintin, C.; Aliev, A. E.; Riddall, D.; Baker, D.; Okuyama, M.; Hoi, P. M.; Hiley, R.; Selwood, D. L. Org. Lett. 2005, 7, 1699.

(173) Kohlbau, H-J.; Thürmer, R.; Voelter, W. Protection of the $\alpha$-Carboxy Group. In "Synthesis of Peptides and Peptidomimetics (Houben-Weyl E22a: Methods of Organic Chemistry)", Goodman, M.; Felix, A.M.; Moroder, L.; Toniolo, C. eds., Georg Thieme Verlag: Stuttgart and New York, 2002, pp. 193-237.

(174) Waldmann, H.; Kunz, H. Liebigs Ann. Chem. 1983, 10, 1712.

(175) Roeske, R. J. Org. Chem. 1963, 28, 1251.

(176) Anderson, G. W.; Callahan, F. M. J. Am. Chem. Soc. 1960, 82, 3359.

(177) Maclaren, J. A. Aust. J. Chem. 1971, 24, 1695. 
(178) Wang, S-S.; Gisin, B. F.; Winter, D. P.; Makofske, R.; Kulesha, I. D.; Tzougraki, C.; Meienhofer, J. J. Org. Chem. 1977, 42, 1286-1290.

(179) Matthews, J. L.; Gademann, K.; Jaun, B.; Seebach, D. J. Chem. Soc. Perk. T. 1, 1998, 20, 3331 .

(180) Ledger, R.; Stewart, F. H. Aust. J. Chem. 1965, 18, 1477.

(181) van Heeswick, W. A. R.; Eenink, M.J. D.; Feijen, J. Synthesis. 1982, 744.

(182) Deimer, K-H. In „XV/1. Synthesis of Peptides, Protecting Groups I (HoubenWeyl: VII. The Synthesis of Peptides", Wünsch, E. ed., Georg Thieme Verlag: Stuttgart, p, 332.

(183) Taylor-Papadimitriou, J.; Yovanidis, C.; Paganou, A.; Zervas, L. J. Chem. Soc. C: Organic 1967, 19, 1830.

(184) Lloyd-Williams, P.; Albericio, F.; Giralt, E. Chemical Approaches to the Synthesis of Peptides and Proteins. Ed. CRC Press, Boca Raton: New York, 1997.

(185) Gatos, D.; Athanassopoulos, P.; Tzavara, C.; Barlos, K. Peptides 1998: Proc 25th European Peptide Symposium, Bajusz, S.; Hudecz, F. eds. Akademiai Kiado: Budapest, 1999, 146-147.

(186) McMurray, J. S. Tetrahedron Lett. 1991, 32, 7679.

(187) Yue, C.; Terry, J.; Potier, P. Tetrahedron Lett. 1993, 34, 323.

(188) Isidro-Llobet, A.; Álvarez, M.; Albericio, F. Tetrahedron Lett, 2008, 49, 3304.

(189) Kessler, H.; Siegmeier, R. Tetrahedron Lett. 1983, 24, 281.

(190) Bednarek M A; Bodanszky, M. Int. J. Pept. Prot. Res. 1983, 21, 196.

(191) Valero, M.-L.; Giralt, E.; Andreu, D. Peptides 1996: Proc 24th European Peptide Symposium. Ramage, R.; Epton, R. (Eds.) Maryflower Scientific Ltd., 1996, 857.

(192) Chan, W. C.; Bycroft, B.W.; Evans, D. J.; White, P. D. J. Chem. Soc., Chem. Commun. 1995, 2209.

(193) Bodanszky M. Int. J. Pept. Prot. Res. 1984, 23, 111.

(194) Martinez, J.; Laur, J.; Castro, B. Tetrahedron Lett. 1983, 24, 5219.

(195) Martinez, J.; Laur, J.; Castro, B. Tetrahedron 1985, 41, 739.

(196) Lloyd-Williams, P.; Jou, G.; Albericio, F.; Giralt, E. Tetrahedron Lett. 1991, 32, 4207.

(197) Alcaro, M. C.; Sabatino, G.; Uziel, J.; Chelli, M.; Ginanneschi, M.; Rovero, P.; Papini, A. M. J. Pept. Sci. 2004, 10, 218. 
(198) Montero, A.; Albericio, F.; Royo, M.; Herradon, B. Eur. J. Org. Chem. 2007, 8, 1301.

(199) Guzman-Martinez, A.; Lamer, R.; VanNieuwenhze, M. S. J. Am. Chem. Soc. 2007, 129, 6017.

(200) Kates, S.; Solé, N. A.; Johnson, C. R.; Hudson, D.; Barany, G.; Albericio, F. Tetrahedron Lett. 1993, 34, 1549.

(201) Kates, S.; Solé, N.; Albericio, F. Barany, G. Peptides: design, synthesis, and biological activity. Basava C.; Anantharamaiah, G.M. eds., Birkhauser: Boston (Massachusetts), 1994, 39-58.

(202) Kates, S.; Daniels, S. B.; Albericio, F. Anal. Biochem. 1993, 212, 303.

(203) Stelakatos, G. C.; Paganou, A.; Zervas, L. J. Chem. Soc. C 1966, 13, 1191.

(204) Hendrickson, J. B.; Kandall, C. Tetrahedron Lett. 1970, 5, 343.

(205) Kuroda, H.; Shigeru, K.; Naowoshi, C.; Terutoshi, K.; Sakakibara, S. Int. J. Pept. Prot. Res. 1992, 40, 114.

(206) Lammert, R.; Ellis, A. I.; Chauvette, R. R.; Kukolja, S. J. Org. Chem. 1978, 43, 1243.

(207) Guibé-Jampel, E.; Wakselman, M. Synth. Commun. 1982, 12, 219.

(208) Romanovskis, P.; Spatola, A. F. J. Pept. Res. 1998, 52, 356.

(209) Schwarz, H.; Arakawa, K. J.; J. Am. Chem. Soc., 1959, 81, 5691.

(210) Royo, M.; Farrera-Sinfreu, J.; Solé, L.; Albericio, F. Tetrahedron Lett. 2002, 43, 2029.

(211) Hocker, M. D.; Caldwell, C. G.; Macsata, R. W.; Lyttle, M. H. Pept. Res. 1995, 8, 310.

(212) Namikoshi, M.; Kundu, B.; Rineheart, K. L. J. Org. Chem. 1991, 56, 5464.

(213) Sieber, P.; Andreatta, R., H.; Eisler, K.; Kamber, B.; Riniker, B.; Rink, H. In Peptides, Proceedings of 5th American Peptide Symposium, Goodman, M.; Meienhofer, J. Eds.; Wiley: New York. (1977). 543.

(214) Wagner, M.; Kunz, H. Synlett 2000, 3, 400.

(215) Wagner, M.; Kunz, H. Zeitschrifft für Naturforschung, B: Chemical Sciences 2002, 57, 928.

(216) Borsuk, K.; van Delft, F. L.; Eggen, I. F.; ten Kortenaar, P. B. W.; Petersen, A.; Rutjes, P. J. T. Tetrahedron Lett. 2004, 45, 3585.

(217) Just, G.; Grozinger, K. Synthesis 1976, 457.

104 
(218) Givens, R. S.; Weber, J. F. W.; Conrad, P. G.; Orosz, G.; Donahue, S.L.; Thayer. S.A. J. Am. Chem. Soc. 2000, 122, 2687.

(219) Lodder, M.; Golovine, S.; Laikhter, A. L.; Karginov, V. A.; Hecht, S. M. J. Org. Chem. 1998, 63, 794.

(220) Bourgault, S.; Letourneau, M.; Fournier, A. Peptides 2007, 28, 1074.

(221) Sedighi, M.; Lipton, M. A. Org. Lett. 2005, 7, 1473.

(222) Taylor, J. W.; Reddy, P.; Patel, K.; Dineen, T.; Naqvi, S. Peptides: The Wave of the Future, Proceedings of the Second International and the Seventeenth American Peptide Symposium, Lebl, M.; Houghten, R. A. Eds. American Peptide Society: San Diego, CA, 2001, 67-68.

(223) Feinberg, R. S.; Merrifield, R. B. J. Am. Chem. Soc. 1975, 97, 3485.

(224) Liu, G.; Zhang, S.-D.; Xia, S.-Q.; Ding, Z.-K. Bioorg. Med. Chem. Lett. 2000, 10, 1361.

(225) Borek, B. A.; Waelsch, H. J. Biol. Chem. 1953, 205, 459.

(226) DiMarchi, R. D.; Tam, J.P.; Merrifield, R. B. Int. J. Pept. Protein Res. 1982, 19, 270.

(227) Tam, J. P.; Riemen, M.W.; Merrifield, R.B. Pept. Res. 1988, 1, 6.

(228) Bodanszky, M.; Kwei, J. Z. Int.J. Pept. Protein Res. 1978, 12, 69.

(229) Mergler, M.; Dick, F.; Sax, B.; Weiler, P.; Vorherr, T. J. Pept. Sci. 2003, 9, 36.

(230) Yajima, H.; Futaki, S.; Otaka, A.; Yamashita, T.; Funakoshi, S.; Bessho, K.; Fujii, N.; Akaji, K. Chem. Pharm. Bull. 1986, 34, 4356.

(231) Thürmer, R.; Kohlbau, H-J.; Voelter, W. Protection of the $\omega$-Carboxy Group. In "Synthesis of Peptides and Peptidomimetics (Houben-Weyl E22a: Methods of Organic Chemistry)" (Goodman, M.; Felix, A.M.; Moroder, L.; Toniolo, C. eds.), Georg Thieme Verlag, Stuttgart and New York, 2002, pp. 238-259.

(232) Kalström, A.; Undén, A. Tetrahedron Lett. 1996, 37, 4243.

(233) Dick, F., Fritschi, U.; Haas, G.; Hässler, O.; Nyfeler, R.; Rapp, E. Peptides 1996: Proc. 24th European Peptide Symposium. Ramage, R.; Epton, R. eds. Maryflower Scientific Ltd., 1998, 339-340.

(234) Ocampo, S. M.; Albericio, F.; Fernandez, I.; Vilaseca, M.; Eritja, R. Org. Lett. 2005, 7, 4349.

(235) Balvinder S.; Murray, T. F.; Aldrich, J. V. J. Med. Chem. 2004, 47, 446.

(236) Kocsis, L.; Bruckdorfer, T.; Orosz, G. Tetrahedron Lett. 2008, 49, 7015. 
(237) Felix, A. M.; Wang, C. T.; Heimer, E. P.; Fournier, A. Int. J. Pept. Prot. Res. 1988, 31, 231.

(238) Bolin, D. R.; Wang, C. T.; Felix, A. M. Org. Prep. Proc. Int. 1989, 21, 67.

(239) Chan, W. C.; Bycroft, B. W.; Evans, D. J.; White, P. D. Peptides 1994, Proceedings of the 23rd European Peptide Symposium, Maia, H. L. S. ESCOM: Leiden, 1995, 153.

(240) Johnson, T.; Liley, M.; Cheeseright, T. J.; Begum, F. J. Chem. Soc., Perk. T. 1, 2000, 2811.

(241) Belshaw, P. J.; Mzengeza, S.; Lajoie, G. A. Synth. Commun. 1990, 20, 3157.

(242) Isidro-Llobet, A.; Álvarez, M.; Albericio, F. Unpublished results.

(243) Sieber, P. Helv. Chim. Acta 1977, 60, 2711.

(244) Marlowe, C. K.; Bioorg. Med. Chem. Lett. 1993, 3, 437.

(245) Meister, S. M.; Kent, S. B. H. In Peptides: Structure, Function, Proceedings to the 8thAmerican Peptide Symposium, Hruby, V. J.; Rich, D. H., eds., Pierce Chemical Company: Rockford, 1983, 103-106..

(246) Kent, S. B. H. Pept.: Struct. Funct. Proc. Am. Pept. Symp. 9th 1985, 407.

(247) Coin, I.; Beyermann, M.; Bienert, M. Nat. Prot. 2007, 2, 3247.

(248) Bedford, J.; Hyde, C.; Johnson, T.; Jun, W.; Owen, D.; Quibell, M.; Sheppard, R.C. Int. J. Pept. Prot. Res. 1992, 40, 300.

(249) Hyde, C.; Johnson, T.; Owen, D.; Quibell, M.; Sheppard, R. C. Int. J. Pept. Prot. Res. 1994, 43, 431.

(250) White, P.; Keyte, J. W.; Bailey, K.; Bloomberg, G. J. Pept. Sci. 2004, 10, 18.

(251) Abedini, Andisheh; Raleigh, Daniel P. Org. Lett. 2005, 7, 693.

(252) Nicolás, E.; Pedroso, E.; Giralt, E. Tetrahedron Lett. 1989, 30, 497.

(253) Yang, Y.; Sweeney, W. V.; Schneider, K.; Thornqvist, S.; Chait, B. T.; Tam, J. P. Tetrahedron Lett. 1994, 35, 9689.

(254) Cebrian, J.; Domingo, V.; Reig, F. J. Pept. Res., 2003, 62, 238.

(255) Zahariev, S.; Guarnaccia, C.; Pongor, C. I.; Quaroni, L.; Cemazar, M.; Pongor, S. Tetrahedron Lett. 2006, 47, 4121.

(256) Mutter, M.; Nefzi, A.; Sato, T.; Sun, X.; Wahl, F.; Wuhr, T. Pept. Res. 1995, 8 , 145.

(257) Haack, T.; Mutter, M.; Tetrahedron Lett. 1992, 33, 1589.

106 
(258) Johnson, T.; Quibell, M.; Owen, D.; Shepard, R. C. J. Chem. Soc. Chem. Commun. 1993, 369.

(259) Isidro-Llobet, A.; Just-Baringo, X.; Álvarez, M.; Albericio, F. Biopolymers. 2008, $90,444$.

(260) Johnson, T. Packman, L.C.; Hyde, C.B.; Owen, D.; Quibell, M. J. Chem. Soc. Perk. T. 1 1996, 719.

(261) Wöhr, T.; Wahl, F.; Netzi, A.; Rohwedder, B.; Sato, T., Sun, X.; Mutter, M. J. Am. Chem Soc. 1996, 118, 9218.

(262) Nicolás, E.; Pujades, M.; Bacardit, J.; Giralt, E.; Albericio, F. Tetrahedron Lett. 1997, 38, 9047.

(263) Garcia-Martin, F.; White, P.; Steinauer, R.; Cote, S.; Tulla-Puche, J.; Albericio, F. Biopolymers 2006, 84, 566.

(264) Johnson, T.; Quibell, M.; Sheppard, R. C. J. Pept. Sci. 1995, 1, 11.

(265) Zeng, W.; Regamey, P-O.; Rose, K.; Wang, Y.; Bayer, E. J. Pept. Res. 1997, 49, 273.

(266) Weygand, F.; Steglich, W.; Bjarnason, J.; Akhtar, R.; Khan, N. M. Tetrahedron Lett. 1966, 29, 3483.

(267) Zahariev, S.; Guarnaccia, C.; Zanuttin, F.; Pintar, A.; Esposito, G.; Maravic, G.; Krust, B.; Hovanessian, A. G.; Pongor, S. J. Pept. Sci. 2005, 11, 17.

(268) Clausen, N.; Goldammer, C.; Jauch, K.; Bayer, E. Peptides 1996: Proc 14th American Peptide Symposium. Ramage, R.; Epton, R. Eds.Maryflower Scientific Ltd.: Kingswinford, UK, 1996, 71-72.

(269) Jauch, K.; Goldammer, C.; Clausen, N.; Bayer, E. In Peptides 1996: Proc 24th European Peptide Symposium. Ramage, R.; Epton, R. eds. Maryflower Scientific Ltd.: Kingswinford, UK 1998, 497-498,

(270) Johnson, E. C. B.; Kent, S. B. H. Chem. Commun. 2006, 1557.

(271) Offer, J.; Quibell, M.; Johnson, T. Innovation and Perspectives in Solid Phase Synthesis \& Combinatorial Libraries: Peptides, Proteins and Nucleic Acids-Small Molecule Organic Chemical Diversity, Collected Papers, International Symposium 5th, Epton, R. ed., Mayflower Scientific Ltd.: Kingswinford, UK

1999, 357-360.

(272) Offer, J.; Johnson, T.; Quibell, M. Tetrahedron Lett. 1997, 38, 9047.

(273) Howe, J.; Quibell, M.; Johnson, T. Tetrahedron Lett. 2000, 41, 3997. 
(274) Wahlstroem, K.; Planstedt, O.; Unden, A. Tetrahedron Lett. 2008, 49, 3921.

(275) Gausepohl, H.; Kraft, M.; Frank, R. W. Int. J. Pept. Prot. Res. 1989, 34, 287.

(276) Mojsov, S.; Mitchell, A. R.; Merrifield, R. B. J. Org. Chem. 1980, 45,, 555-.

(277) Doherty-Kirby, A.; Lajoie, G. A. Side-Chain Protecting Groups. Solid-Phase Synthesis, A Practical Guide, Kates, S. A.; Albericio, F. eds., Marcel Dekker Inc.: New York. 2000, 103-128.

(278) Dimarchi, R. D.; Tam, J. P.; Kent, S. B. H.; Merrifield, R. B. Int. J. Pept. Prot. Res. 1982, 19, 88.

(279) Quesnel, A.; Briand, J.-P. J. Pept. Res. 1998, 52, 107.

(280) Friede M; Denery S; Neimark J; Kieffer S; Gausepohl H; Briand J. P. Pept. Res. 1992, 5, 145 .

(281) Sieber, P.; Riniker, B. Tetrahedron Lett. 1991, 32, 739.

(282) Shimonishi, Y.; Sakakibara, S.; Akabori, S. Bull. Chem. Soc. Jpn. 1962, 35, 1966.

(283) Han, Y.; Sole, N. A.; Tejbrant, J.; Barany, G. Pept. Res. 1996, 9, 166.

(284) Sax, B.; Dick, F.; Tanner, R.; Gosteli, J. J. Pept. Res. 1992, 5, 245.

(285) Carpino, L. A.; Chao, H.-G. WO 9526976 . Chem. Abstr. 1995, 124, 146865.

(286) Carpino, L. A.; Shroff, H. N.; Chao, H.-G.; Mansour, E. M. E.; Albericio, F. Peptides 1994, Proceedings of the 23rd European Peptide Symposium, Maia, H. L. S. ESCOM: Leiden, 1995. 155-156.

(287) Konig, W.; Geiger, R. Chem. Ber. 1970, 103, 2041-2051.

(288) Funakoshi, S. ; Tamamura, H.; Fujii, N. ; Yoshizawa, K. ; Yajima, H. ; Miyasaka, K. ; Funakoshi, A.; Ohta, M. ; Inagaki, Y. ; Carpino, L. A. J. Chem. Soc., Chem. Comm. 1988, 24, 1588 .

(289) Hudson, D. Eur. Pat. Appl. EP 292228 A2, 1988, Chem. Abstr. 1989, 110, 213367.

(290) Shah, D.; Schneider, A.; Babler, S.; Gandhi, R.; Van Noord, E.; Chess, E. Pept. Res. 1992, 5, 241.

(291) Rink, H.; Sieber, P.; Raschdorf, F. Tetrahedron Lett., 1984, 25, 621.

(292) Du Vigneaud, V.; Gish, D. T.; Katsoyannis, P. G.; Hess, G. P. J. Am. Chem. Soc., 1958, $80,3355$.

(293) Jones, D. A.; Miculec, R. A.; Mazur, R. H. J. Org. Chem. 1973, 38, 2865.

108 
(294) Ponsati, B.; Canas, M.; Jodes, G.; Clemente, J.; Barcadit, J. PCT Int. Appl. 2000, WO 2000071570 A1, 2000, Chem. Abstr. 134, 17728.

(295) Ramage, R.; Green, J.; Blake, A. J. Tetrahedron 1991, 47, 6353.

(296) Kiso, Y.; Satomi, M.; Ukawa, K.; Akita, T. J. Chem. Soc. Commun. 1980, 1063.

(297) Ramachandran, J.; Li, C. H. J. Org. Chem. 1962, 27, 4006.

(298) Carpino, L. A.; Shroff, H.; Triolo, S. A.; Mansour, El Sayed M. E.; Wenschuh, H.; Albericio, F. Tetrahedron Lett. 1993, 34, 7829.

(299) Yajima, M.; Akaji, K.; Mitani, N.; Fujii, N.; Funakoshi, S.; Adachi, H.; Oishi, M.; Akazawa, Y. Int. J. Pept. Prot. Res. 1979, 14, 169.

(300) Yajima, M.; Takeyama, M.; Kanaki, J.; Mitani, N. J. Chem. Soc. Chem. Commun. 1978, 482.

(301) Atherton, E.; Sheppard, R. C.; Wade, J. D. J. Chem. Soc. Chem. Commun. 1983, $19,1060$.

(302) Isidro-Llobet, A.; Álvarez, M.; Albericio, F. J. Org. Chem. 2008 (submitted).

(303) Lundt, B. F.; Johansen, N. L.; Volund, A.; Markussen, J. Int. J. Pept. Protein Res. 1978, 12, 258.

(304) Verdini, A. S.; Lucietto, P.; Fossati, G.; Giordani, C. Peptides, Chemistry and Biology, Proceedings of the 12th American Peptide Symposium. Smith, J. A.; Rivier, J. E. eds. ESCOM: Leiden, 1992, 562-563.

(305) Verdini, A. S.; Lucietto, P. ; Fossati, G.; Giordani, C. Tetrahedron Lett. 1992, 33, 6541.

(306) Noda, M.; Kiffe, M. J. Pept. Res. 1997, 50, 329.

(307) Bergmann, M.; Zervas, L.; Rinke, H. H-S Z. Physiol. Chem. 1934, 224, 40.

(308) Young, G. T.; Schafer, D. J.; Elliott, D. F.; Wade, R., J. Chem. Soc. C. 1971, 46.

(309) Tamura, S. Y.; Semple, J. E.; Ardecky, R. J.; Leon, P.; Carpenter, S.H.; Ge, Y.; Shamblin, B. M.; Weinhouse, M. I.; Ripka, W. C.; Nutt, R. F. Tetrahedron Lett. 1996, 37, 4109 .

(310) Semple, J. E.; Rowley, D. C.; Brunck, T. K.; Ha-Uong, T.; Minami, N. K.; Owens, T. D.; Tamura, S.Y.; Goldman, E. A.; Siev, D. V.; Ardecky, R. J.; Carpenter, S. H.; Ge, Y.; Richard, B. M.; Nolan, T. G.; Hakanson, K.; Tulinsky, A.; Nutt, R. F.; Ripka, W.C. J. Med. Chem. 1996, 39, 4531.

(311) Krishnamoorthy, R.; Vazquez-Serrano, L. D.; Turk, J. A.; Kowalski, J. A.; Benson, A. G.; Breaux, N. T.; Lipton, M. A. J. Am. Chem. Soc. 2006, 128, 15392. 
(312) Molnar-Perl, I.; Fabian-Vonsik, V. J. Chromatogr. 1988, 446, 231.

(313) Sarkar, S. K.; Malhotra, S. S. J. Chromatogr. 1979, 170, 371.

(314) Bartoli, S.; Jensen, K. J.; Kilburn, J. D. J. Org. Chem. 2003, 68, 9416-9422.

(315) Calimsiz, S.; Morales Ramos, A. I.; Lipton, M. A. J. Org. Chem. 2006, 71, 6351.

(316) Eisele, F.; Kuhlmann, J.; Waldmann, H. Chemistry-A European Journal. 2002, 8,3362 .

(317) Barany, G.; Merrifield, R. B. The Peptides Analysis, Synthesis, Biology, Vol. 2, Special Methods in Peptide Synthesis, Part A, Gross, E.; Meienhofer, J. Eds. Academic Press: New York, 1979, 1.

(318) Yajima, H.; Funakoshi, S.; Fujii, N.; Akaji, K.; Irie, H. Chem. Pharm. Bull. 1979, 27,1060 .

(319) Yajima, H.; Akaji, K.; Funakoshi, S.; Fujii, N.; Irie, H. Chem. Pharm. Bull. 1980, 28, 1942.

(320) Lukszo, J.; Patterson, D.; Albericio, F.; Kates, S. A. Lett. Pept. Sci. 1996, 3, 157.

(321) Eritja, R.; Ziehler-Martin, J. P.; Walker, P. A.; Lee, T. D.; Legesse, K.; Albericio, F.; Kaplan, B. E. Tetrahedron 1987, 43, 2675.

(322) Nacagawa,Y.; Nishiuchi, Y.; Emura, J.; Sakakibra, S. In Peptide Chemistry 1980, Okawa, K. Ed.: Protein Research Foundation: Osaka, 1981, 41.

(323) Musiol, H-J.; Siedler, F.; Quarzago, D.; Moroder, L. Biopolymers 1994, 34, 1553.

(324) Lamthanh, H.; Roumestand, C.; Deprun, C.; Menez, A. Int. J. Pept. Prot. Res. 1993, 41,85 .

(325) Lamthanh, H.; Virelizier, H., Frayssinhes. Pept. Res. 1995, 8, 316.

(326) Engebretsen, M.; Agner, E.; Sandosham, J.; Fischer, P. M. J. Pept. Res. 1997, 49, 341.

(327) Kumagaye, K. Y.; Inui, T.; Nakajima, K.; Kimura, T.; Sakakibara, S. Pept. Res. 1991, 4,84 .

(328) Gesquière, J. C.; Najib, J.; Diesis, E.; Barbry, D..; Tartar, A. Peptides, Chemistry and Biology, Proceedings of the 12th American Peptide Symposium, Smith, J. A.; Rivier, J. E. eds., ESCOM: Leiden, 1992, 641.

(329) Kaiser, E. T.; Nicholson, G. J.; Kohlbau, H. J.; Voelter, W. Tetrahedron Lett. 1996, 37, 1187. 
(330) Atherton, E.; Hardy, P. M.; Harris, D. E.; Mathews, B. H. Peptides 1990, Proceedings of the 21st European Peptide Symposium. Giralt, E.; Andreu, D. eds. ESCOM: Leiden, 1991, 243-244.

(331) Fujiwara, Y.; Akaji, K.; Kiso, Y. Chem. Pharm. Bull. 1994, 42, 724.

(332) Han, Y.; Albericio, F.; Barany, G. J. Org. Chem. 1997, 62, 4307.

(333) Angell, Y. M.; Alsina, J.; Albericio, F.; Barany, G. J. Pept. Res. 2002, 60, 292.

(334) Siedler, F.; Weyher, E.; Moroder, L. J. Pept. Sci. 1996, 2, 271.

(335) Moroder, L.; Musiol, H-J.; Schaschke, N.; Chen, L.; Hargittai, B.; Barany, G. Protection of the Thiol Group. In "Synthesis of Peptides and Peptidomimetics (HoubenWeyl E22a: Methods of Organic Chemistry)" (Goodman, M.; Felix, A.M.; Moroder, L.; Toniolo, C. eds.), Georg Thieme Verlag, Stuttgart and New York, 2002, 384-424.

(336) Atherton, E.; Benoiton, N. L.; Brown, E.; Sheppard, R. C.; Williams, B. J. J. Chem. Soc. Chem. Commun. 1981, 336.

(337) Richter, L. S.; Marsters, J. C.; Gadek, T. R. Tetrahedron Lett. 1994, 35, 1631.

(338) Erickson, B. W.; Merrifield, R. B. J. Am. Chem. Soc. 1973, 95, 3750.

(339) Heath, W. F.; Tam, J.; Merrifield, R. B. Int. J. Pept. Protein Res. 1986, 28, 498.

(340) Sakakibara, S. Biopolymers 1995, 37, 17.

(341) Fujii, N.; Otaka, A.; Funakoshi, S.; Bessho, K.; Watanabe, T.; Akaji, K.; Yajima, H. Chem. Pharm. Bull. 1987, 35, 2339.

(342) Yajima, H.; Fujii, M.; Ogawa, H.; Kawatami, H. J. Chem. Soc. Chem. Commun. 1974, 107-

(343) Nishimura, O.; Kitada, C.; Fujino, M. Chem. Pharm. Bull. 1978, 26, 1576.

(344) Fuji, N.; Otaka, A.; Watanabe, T.; Okamachi, A.; Tamamura, H.; Yajima, H.; Inagaki, Y.; Nomizu, M.; Asano, K. J. Chem. Soc. Chem. Commun. 1989, 283.

(345) Akaji, K. ; Tatsumi, T.; Yoshida, M. ; Kimura, T.; Fujiwara, Y.; Kiso, Y. J. Chem. Soc. Chem. Commun. 1991, 3, 167.

(346) Akabori, S.; Sakakibara, S.; Shimonishi, Y.; Nobuhara, Y. Bull. Chem. Soc. Jpn. 1964, 37, 433.

(347) Zervas, L.; Photaki, I. J. Am. Chem. Soc. 1962, 84, 3887.

(348) Yajima, H.; Fujii, N.; Funakoshi, S.; Watanabe, T.; Murayama, E.; Otaka, A. Tetrahedron 1988, 44, 805.

(349) Barlos, K.; Gatos, D.; Hatzi, O.; Koch, N.; Koutsogianni, S. Int. J. Pept. Prot. Res. 1996, 47, 148. 
(350) Munson, M. C.; García-Echevarría, C.; Albericio, F.; Barany, G. J. Org. Chem. 1992,57, 3013 .

(351) García, O.; Nicolás, E.; Albericio, F. Innovation and Perspectives in Solid Phase Synthesis and Combinatorial Libraries: Peptides, Proteins and Nucleic Acids-Small Molecule Organic Chemistry Diversity Collected Papers, International Symposium, 6th. Epton, R. ed. Mayflower Scientific Ltd.: Kingswinford, UK, 2001, 289-290.

(352) Sifferd, R. H.; du Vigneaud, V. J. Biol. Chem. 1935, 108, 753.

(353) Pastuszak, J. J.; Chimiak, A. J. Org. Chem.1981, 46, 1868.

(354) Bodanszky, M.; Bednarek, M. A. Int. J. Pept. Prot. Res. 1982, $20,434$.

(355) Ruiz-Gayo, M.; Albericio, F.; Pedroso, E.; Giralt, E. J. Chem. Soc., Chem. Commun. 1986, 20, 1501.

(356) Royo, M.; Garcia-Echeverria, C.; Giralt, E.; Eritja, R.; Albericio, F. Tetrahedron Lett. 1992, 33, 2391.

(357) West, C. W.; Estirarte, M. A.; Rich, D. H. Org. Lett. 2001, 3, 1205.

(358) Veber, D. F.; Milkowski, J. D.; Varga, S. L.; Denkewalter, R. G.; Hirschmann, R. J. Am. Chem. Soc. 1972, 94, 5456.

(359) Kamber, B. Helv. Chim. Acta 1971, 54, 927.

(360) Lyle, T. A.; Brady, S. F.; Ciccarone, T. M.; Colton, C. D.; Paleveda, W. J.; Veber, D. F.; Nutt, R. F. J. Org. Chem. 1987, 52, 3752-3759.

(361) Singh, P. R.; Rajopadhye, M.; Clark, S. L.; Williams, N. E. Tetrahedron Lett. 1996, 37, 4117.

(362) Royo, M.; Alsina, J.; Giralt, E.; Slomcyznska, U.; Albericio, F. J. Chem. Soc., Perk. T. 1. 1995, 9, 1095.

(363) Weber, U.; Hartter, P. Hoppe-Seyler's Z. Physiol. Chem. 1970, 351, 1384-1388.

(364) Wünsch, E. In „XV/1. Synthesis of Peptides, Protecting Groups I (Houben-Weyl: VII. The Synthesis of Peptides", Wünsch, E. ed., Georg Thieme Verlag: Stuttgart, p 789.

(365) Wünsch, E.; Spangenberg, R. Ger. Offen. 1971, DE 1923480 1971012. 1971, Chem. Abstr. 74, 88309.

(366) Moroder, L.; Gemeiner, M.; Göhring, W.; Jaeger, E.; Wünsch, E. In Peptides 1980, Brundfeldt, K., Ed.; Scriptor: Copenhagen, 1981, 121.

(367) Atherton, E.; Sheppard, R. C.; Ward, P. J. Chem. Soc. Perk. T. 1. 1985, 2073.

(368) Matsueda, R.; Kimura, T.; Kaiser, E. T.; Matsueda, G. R. Chem. Lett. 1981, 737. 
(369) Albericio, F.; Andreu, D.; Giralt, E.; Navalpotro, C.; Pedroso, E.; Ponsati, B.; Ruiz-Gayo, M. Int. J. Pept. Prot. Res. 1989, 34, 124.

(370) Bernatowicz, M. S.; Matsueda, R.; Matsueda, G. R. Int. J. Pept. Prot. Res. 1986, $28,107$.

(371) Huang, H.; Carey, R. I. J. Pept. Res. 1998, 51, 290.

(372) Gómez-Martínez, P.; Guibé, F.; Albericio, F. Lett. Pept. Sci. 2001, 7, 187.

(373) Tatsu, Y.; Endo, Y.; Yumoto, N. Pept. Sci. 2003, 405.

(374) Pan, P.; Bayley, H. FEBS Lett. 1997, 405, 81.

(375) Bland, L.; Ramage, R. Innovation and Perspectives in Solid Phase Synthesis and Combinatorial Librharies: Peptides, Proteins and Nucleic Acids-Small Molecule Organic Chemistry Diversity Collected Papers, International Symposium, 6th. Epton, R. ed. Mayflower Scientific Ltd.: Kingswinford, UK, 2001, 247-248.

(376) Pool, C. T.; Boyd, J. G.; Tam, J. P. J. Pept. Res. 2004, 63, 223.

(377) Werbitzky, O.; Oehlers, D. Chim. Oggi, 2008, 26(4), 26.

(378) Gairí, M.; Lloyd-Williams, P.; Albericio, F.; Giralt, E. Tetrahedron Lett. 1994, $35,175$.

(379) Guttmann, S.; Boissonnas, R. A. Helv. Chim. Acta 1959, 42, 1257.

(380) Yajima, H.; Kanaki, J.; Kitajima, M.; Funakoshi, S. Chem. Pharm. Bull. 1980, 28, 1214.

(381) Iselin, B. Helv. Chim. Acta. 1961, 44, 61.

(382) Houghten, R.A.; Li, C.H. Peptides, Chemistry, Structure \& Biology, Proc. 5th American Peptide Symposium, Goodman, M.; Meienhofer, J. eds., Pierce Chemical Company: Rockford, 1977, 458.

(383) Houghten, R.A.; Li, C.H. Int. J. Pept. Prot. Res. 1978, 11, 345.

(384) Houghten, R.A.; Li, C.H. Anal. Biochem. 1979, 98, 36.

(385) Ferrer, T.; Nicolás, E.; Giralt, E. Lett. Pept. Sci. 1999, 6, 165.

(386) Vilaseca, M.; Nicolás, E.; Capdevila, F.; Giralt, E. Tetrahedron. 1998, 54, 15273.

(387) Andreu, D.; Nicolas, E. Solid-Phase Synthesis, A Practical Guide, Kates, S. A.; Albericio, F. eds., Marcel Dekker Inc.: New York, 2000, 365-375.

(388) Pennington, M. W.; Byrnes, M. E. Pept. Res. 1995, 8, 39.

(389) Beck, W.; Jung, G. L.I.P.S. 1994, 1, 31.

(390) Teixidó, M.; Altamura, M.; Quartara, L.; Giolitti, A.; Maggi, C. A.; Giralt, E.; Albericio, F. J. Comb. Chem. 2003, 5, 760. 
(391)Taboada, L.; Nicolas, E.; Giralt, E. Tetrahedron Lett. 2001, 42, 1891.

(392) Fukaki, S.; Yagami, T.; Taike, T.; Akita, T.; Kitagawa, K. J. Chem. Soc. Perk. T. I. 1990, 653.

(393) Noble, R. L.; Yamashiro, D.; Li, C. H. J. Am. Chem. Soc. 1976, 98, 2324.

(394) Riniker, B.; Brugger, M.; Kamber, B.; Rittel, W.; Sieber P. Progress in Peptide Research, Vol. II, Proceedings of the Second American Peptide Symposium, Lande, S. ed., Gordon and Breach: New York, 1972, 116.

(395) Jones, J. H. Protection of the Imidazole Group. In "Synthesis of Peptides and Peptidomimetics (Houben-Weyl E22a: Methods of Organic Chemistry)”, Goodman, M.; Felix, A.M.; Moroder, L.; Toniolo, C. eds., Georg Thieme Verlag: Stuttgart and New York, 2002, pp. 334-346.

(396) Kusunoki, M.; Nakagawa, S.; Seo, K.; Hamana, T.; Fukuda, T. Int. J. Pept. Prot. Res. 1990, 36, 381.

(397) Ishiguro, T.; Eguchi, C. Chem. \& Pharm.l Bull. 1989, 37, 506.

(398) Jones, J. H.; Ramage, W. I.; Witty, M. J. Int. J. Pept. Res. 1980, 15, 301.

(399) Fujii, T; Sakakibara, S. Bull. Chem. Soc. Jpn. 1974, 47, 3146.

(400) Fujii, T; Kimura, T.; Sakakibara, S. Bull. Chem. Soc. Jpn. 1976, 49, 1595.

(401) Sieber, P.; Riniker, B. Tetrahedron Lett. 1987, 28, 6031.

(402) Barlos, K.; Chatzi, O.; Gatos, D.; Stravropoulos, G.; Tsegenidis, T. Tetrahedron Lett. 1991, 32, 475.

(403) Karlström, A.; Undén, A. J. Chem. Soc. Chem. Commun. 1996, 959.

(404) Yoshizawa-Kumagaye, K.; Nishiuchi, Y.; Nishio, H.; Kimura, T. J. Pept. Sci. 2005, 11, 512-515.

(405) Colombo, R.; Colombo, F.; Jones, J. H. J. Chem. Soc. Chem. Commun. 1984, 292. (406) Mergler, M.; Dick, F.; Sax, B.; Schwindling, J.; Vorherr, T. J. Pept. Sci. 2001, 7, 502 .

(407) Atherton, E.; Cammish, L. E.; Goddard, P.; Richards, J. D.; Sheppard, R. C. Pept., Proc. Eur. Pept. Symp., 18th 1984, 153.

(408) Zaramella, S.; Strömberg, R.; Yeheskiely, E. Eur. J. Org. Chem. 2003, 2454.

(409) Chillemi, F.; Merrifield, R. B. Biochemistry 1969, 8, 4344.

(410) Shaltiel, S.; Biochem. Phys. Res. Commun. 1967, 29, 178.

(411) Shaltiel, S.; Fridkin, M. Biochemistry, 1970, 9, 5122.

114 
(412) Gesquière, J. C.; Najib, J.; Latailler, T.; Maes, P.; Tartar, A. Tetrahedron Lett. 1993, 34, 1921.

(413) Stewart, J. M.; Knight, M.; Paiva, A. C. M.; Paiva, T. Progress in Peptide Research. Lande, S. (Ed.) 1972, 59-64.

(414) Fischer, P. M; Retson, K. V.; Tyler, M. I.; Howden, M. E. H. Int. J. Pept. Prot. Res, 1991, 38, 491.

(415) Reissmann, S.; Schwuchow, C.; Seyfarth, L.; Pineda De Castro, L. F.; Liebman, C.; Paegelow, I.; Werner, H.; Stewart, J. J. Med. Chem. 1996, 39, 929.

(416) Shvachkin, Yu. P.; Girin, S. K.; Smirnova, A. P.; Shishkina, A. A.; Ermak, N. M. Bioorg. Khim. 1980, 6, 187.

(417) Arold, H.; Reissmann, S. J. Prakt. Chem. 1970, 312, 1130.

(418) Adamson, J. G.; Blaskowitch, M. A.; Groenvelt, H.; Lajoie, G. A. J. Org. Chem. 1991, 56, 3447.

(419) Hruby, V. J.; Ehler, K. W. J. Org. Chem. 1970, 35, 1690.

(420) Sugano, H.; Miyoshi, M. J. Org. Chem. 1976, 41, 2352.

(421) Mizoguchi, T.; Levin, G.; Woolley, D. W.; Stewart, J. M. J. Org. Chem. 1968, 33, 903.

(422) Wang, J.; Okada, W. Li; Yokoi, T.; Zhu, J. J. Chem. Soc. Perk. T. I, 1997, 621.

(423) Barlos, K.; Gatos, D.; Koutsogianni, S.; Schäfer, W.; Stavropoulous, G.; Yenqing, Y. Tetrahedron Lett. 1991, 32, 471.

(424) Fischer, P. M. Tetrahedron Lett. 1992, 33, 7605.

(425) Reid, G. E.; Simpson, R. J.; Anal. Biochem. 1992, 200, 301.

(426) Nishiyama, Y.; Kurita, K. Tetrahedron Lett. 1999, 40, 927.

(427) Arzeno, H. B.; Beinfenheimer, W.; Blanchette, R.; Morgans, D. J.; Robinson III, J. Int. J. Pept. Prot. Res. 1993, 41, 342.

(428) Barlos, K.; Gatos, D.; Koutsogiammi, S. J. Pept. Res. 1998, 51, 194.

(429) Lalonde, M.; Chan, T. H. Synthesis 1985, 817.

(430) Davies, J. S.; Higginbotham, C. L.; Tremeer, E. J.; Brown, C.; Treadgold, R. C. J. Chem. Soc., Perk. T. 1. 1992, 22, 3043.

(431) Pirrung, M. C.; Nunn, D. S. Bioorg. Med. Chem. Lett. 1992, 2, 1489.

(432) Lemke, E. A.; Summerer, D.; Geierstanger, B. H.; Brittain, S. M.; Schultz, P. G. Nat. Chem. Biol. 2007, 3, 769. 
(433) Ramesh, R.; De, Kavita; Gupta, S.; Chandrasekaran, S. J. Chem. Sci. 2008, 120, 163.

(434) Yamashiro, D.; Li, C. H. J. Am. Chem. Soc. 1973, 95, 1310.

(435) Yamashiro, D.; Li, C. H. J. Org. Chem. 1973, 38, 591.

(436) Yamashiro, D.; Li, C. H. Int. J. Pept. Protein Res. 1972, 4, 181.

(437) Salem, E. M.; Schou, O. Indian J. Chem. Sect. B. 1980, 19, 62.

(438) Rosenthal, K.; Kalström, A.; Unden, A. Tetrahedron Lett. 1997, 38, 1075.

(439) Bódi, J.; Nishiuchi, Y.; Nishio, H.; Inui, T.; Kimura, T. Tetrahedron Lett. 1998, $39,7117$.

(440) Smith, C. W.; Ferger, M. F. J. Med. Chem. 1975, 18, 822.

(441) Barlos, K.; Gatos, D.; Kapolos, S.; Poulos, C.; Schäfer, W.; Yao, W. Int. J. Pept. Protein Res.. 1991, 38, 555.

(442) Dangles, O.; Guibé, F.; Balavoine, G.; Lavielle, S.; Marquet, A. J. Org. Chem. 1987, 52, 4984.

(443) Amit, B.; Hazum, E.; Fridkin, M.; Patchornik, A. Int. J. Pept. Prot. Res. 1977, 9, 91.

(444) Tatsu, Y.; Shigeri, Y.; Sogabe, S.; Yumoto, N.; Yoshikawa, S. Biochem. Biophys. Res. Commun. 1996, 227, 688.

(445) Wahlstroem, K.; Planstedt, O.; Unden, A. Tetrahedron Lett. 2008, 49, 3779.

(446) Fontana, A.; Toniolo, C. Fort. Chem. Org. Nat. 1976, 33, 309.

(447) Giraud, M. ; Cavelier, F.; Martinez, J. J. Pept. Sci. 1999, 5 , 457.

(448) Omori,Y.; Matsuda, Y.; Aimoto, S.; Shimonishi, Y.; Yamamoto, M. Chem. Lett. 1976, 805.

(449) Andreu, D.; García, F. J. Lett. Pept. Sci. 1997, 4, 41.

(450) Pearson, D. A.; Blanchette, M.; Baker, M. L.; Guindon, C. A. Tetrahedron Lett. 1989, 30, 2739.

(451) Sieber, P.; Tetrahedron Lett. 1987, 28, 1637.

(452) Stierandova, A.; Sepetov, N.; Nikiforovich, G. V.; Lebl, M. Int. J. Pept. Prot. Res. 1994, 41,31 .

(453) Karlström, A.; Unden, A. J. Chem. Soc. Chem. Commun. 1996, 1471.

(454) Nishiuchi, Y.; Nishio, H.; Inui, T.; Kimura, T.; Sakakibara, S. Tetrahedron Lett. 1996, 37, 7529. 
(455) White, P. Peptides, Chemistry and Biology, Proceedings of the 12th American Peptide Symposium. Smith, J. A.; Rivier, J.E. eds. ESCOM: Leiden, 1992, 537-538.

(456) Franzen, H.; Grehn, L.; Ragnarsson, U. J. Chem. Soc. Chem. Commun. 1984, 1699.

(457) Vorherr, T.; Trzeciak, A.; Bannwarth, W. Int. J. Pept. Prot. Res. 1996, 48, 553.

(458) Ohno, M.; Tsukamoto, S.; Makisumi, S.; Izumiya, N. Bull. Chem. Soc. Jpn. 1972, 45, 2852.

(459) Yamashiro, D.; Li, C. H. J. Org. Chem. 1973, 38, 2594.

(460) Matsueda, G. R. Int. J. Pept. Prot. Res. 1982, 20, 26.

(461) Geiger, R.; König, W. The Peptides. Analysis, Synthesis, Biology. Vol. 3, Protection of Functional Groups in Peptide Synthesis. Gross, E. and Meienhofer, J. eds. Academic Press: New York. 1981, 1.

(462) Merrifield, R. B.; Vizioli, L. D.; Boman, H. G. Biochemistry 1982, 21, 5020.

(463) Choi, H.; Aldrich J. V. Int. J. Pept. Prot. Res. 1993, 42, 58.

(464) Fields, C. G.; Fields, G. B. Tetrahedron Lett. 1993, 34, 6661.

(465) Nishiuchi, Y.; Nishio, H.; Inui, T.; Bodi, J. Kimura, T. Innovation and Perspectives in Solid Phase Synthesis and Combinatorial Libraries: Peptides, Proteins and Nucleic Acids-Small Organic Chemistry Diversity, Collected Papers, International Symposium, 6th. Epton, R. ed. Mayflower Scientific Ltd.: Kingswinford, UK, 2001, 331-332.

(466) Nishio, H.; Nishiuchi, Y.; Inui, T.; Nakata, M.; Yoshizawa-Kumagaye, K.; Kimura, T. Peptides: The Wave of the Future. Proceedings of the Seventeenth American Peptide Symposium, Lebl, M.; Houghten, R. A. eds. American Peptide Society: San Diego, CA, 2001, 248-249.

(467) Fujii, N.; Futaki, S.; Yasumura, K.; Yajima, H. Chem. Pharm. Bull. 1984, 32, 2660.

(468) Miyoshi, K.; Otaka, A.; Kaneko, M.; Tamamura, H.; Fujii, N. Chem. Pharm. Bull. 2000, 48, 1230. 